\title{
Lower Carboniferous Foraminiferal Faunas of the Boring Orslev No. 1, Island of Falster, Denmark
}

\author{
BY \\ Olaf Michelsen
}

DANSK SAMMENDRAG

Nedre karbone foraminiferfaunaer fra boringen

Orslev nr. 1, Falster, Danmark

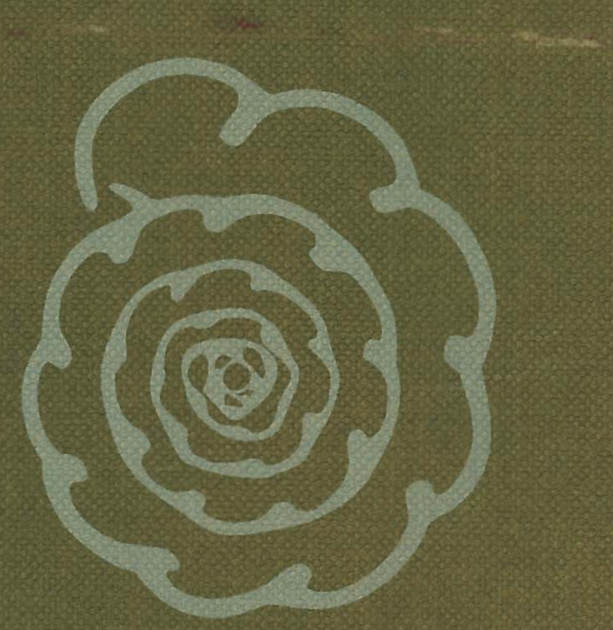

I kommission hos C. A. Reilzels Forlag. Kobenhavn 1971 
DANMARKS GEOLOGISKE UNDERSØGELSE

II. RÆKKE. NR. 98

Geological Survey of Denmark. II. Series. No. 98

\title{
Lower Carboniferous Foraminiferal Faunas of the Boring Ørslev No. 1, Island of Falster, Denmark
}

\author{
By \\ Olaf Michelsen
}

Dansk sammendrag:

Nedre karbone foraminiferfaunaer fra boringen

Ørslev nr. 1, Falster, Danmark

I kommission hos

C. A. REITZELS FORLAG

KøBENHAVN 1971 
D.G.U. II. rk. nr. 98

er sat med Linotype Times

og trykt i 1500 eksemplarer

hos Andelsbogtrykkeriet i Odense.

Papiret er ekstraglittet 605, $125 \mathrm{~g}$

fra a/s De forenede Papirfabrikker.

ISBN 8742106176

With 22 plates 


\section{CONTENTS}

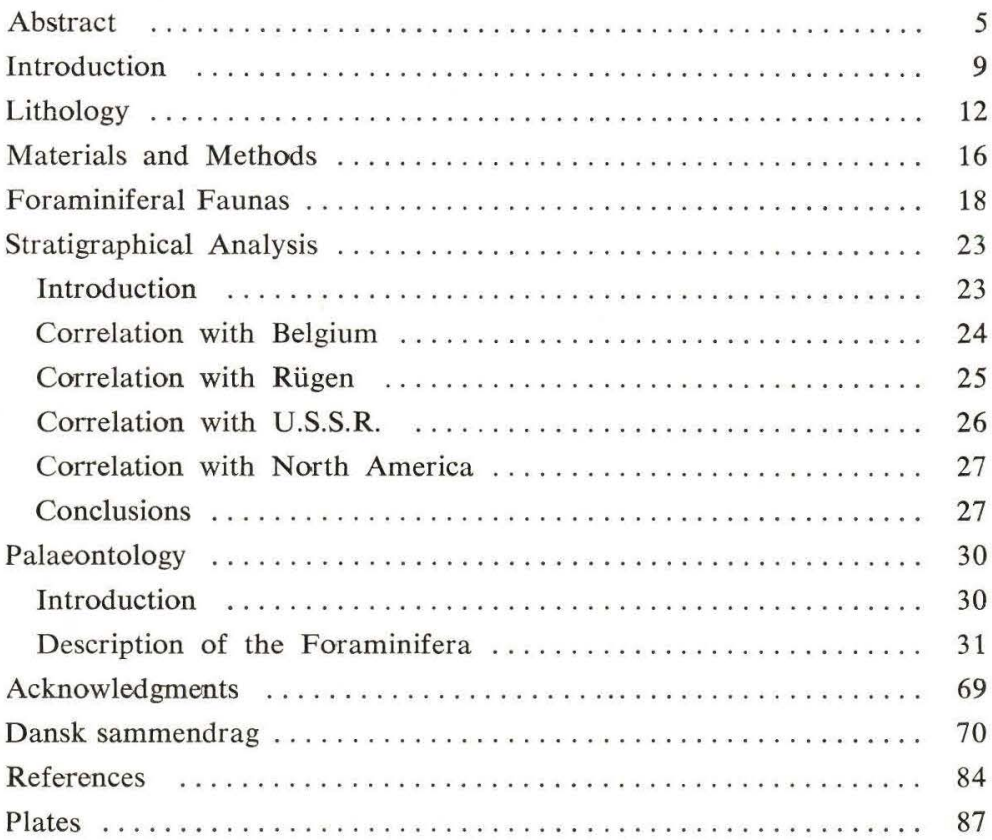




\begin{abstract}
Lower Carboniferous foraminifera from a $1700^{\prime}$ thick series of limestone, marlstone, and claystone in the boring Ørslev No. 1 are studied.

48 forms are described. 17 of these are identified to species, two of which are established as new species and two as new subspecies, namely Lituotubella glomospiroides minima n. subsp., Septabrunsiina spissusvoluta n. sp., Endothyra danica n. sp., and E. michoti spinata n. subsp. The remaining 31 forms are given with open nomenclature; nine of these are morphospecies, provisionally referred to already known species. The study and description of the foraminifera are based on the external morphology of the tests and on defined sections of the tests.

On the basis of the biostratigraphy, the deposits are referred to the Lower and Middle (?) Visean. The interval $6740^{\prime}-6945^{\prime}$, which has a fauna dominated by the family Ozawainellidae, may probably be correlated with certain parts of the Russian and the Belgian Middle Visean (Visean 2), while the interval 6945'-8440' correlates with the Lower Visean in Belgium (Visean 1) on the basis of its faunas, characterized by the genus Endothyra.
\end{abstract}


$\oslash R S L E V \quad$ No. 1

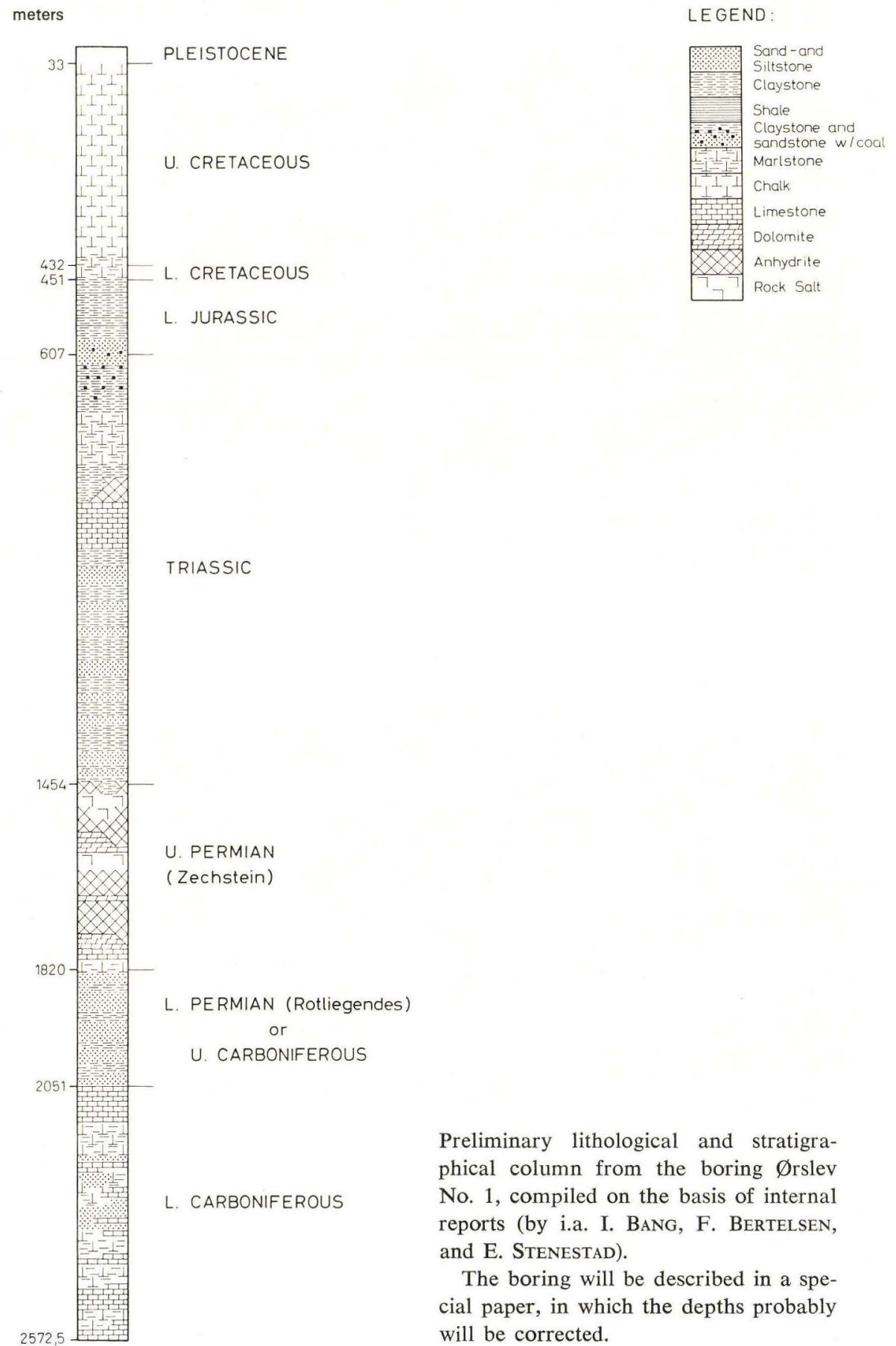




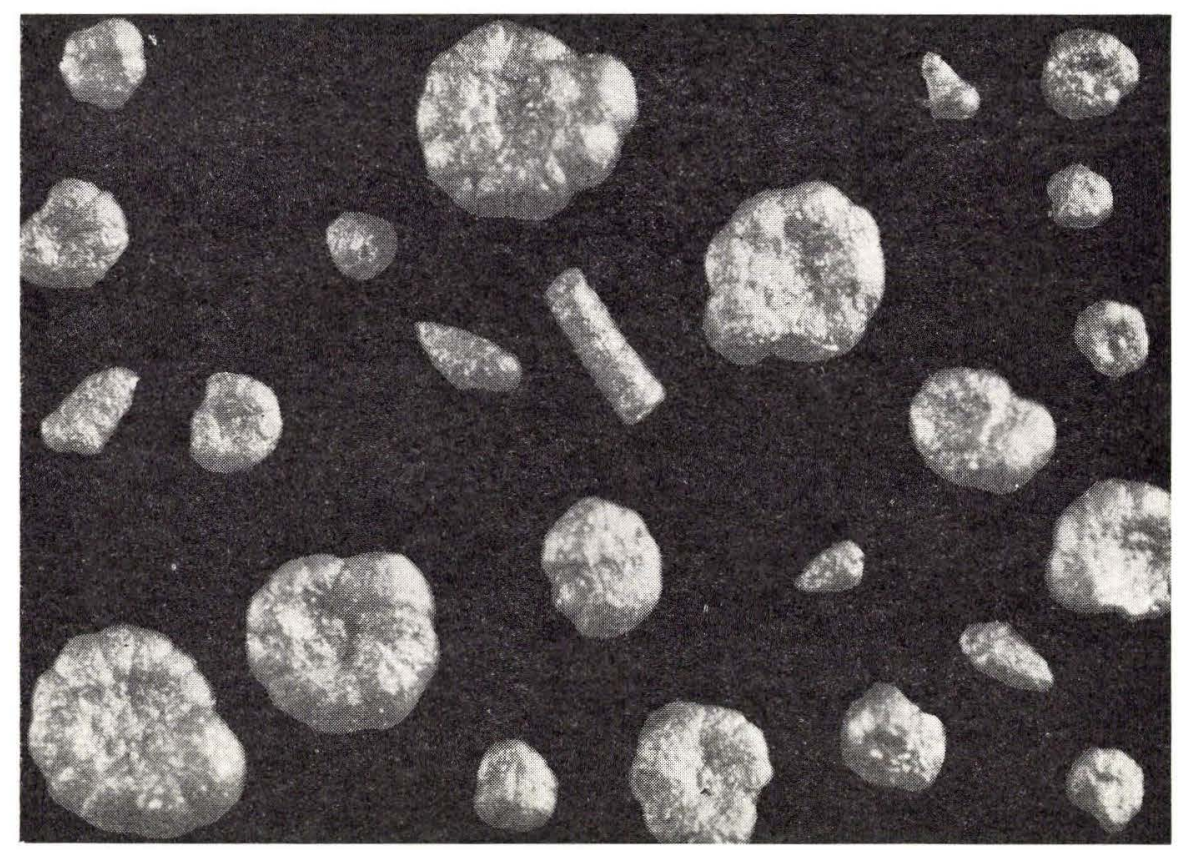

Section of the foraminiferal fauna from the depth $7712^{\prime} 7^{\prime \prime}-7713^{\prime}$, core No. 2 (zone III). $23 \mathrm{x}$.

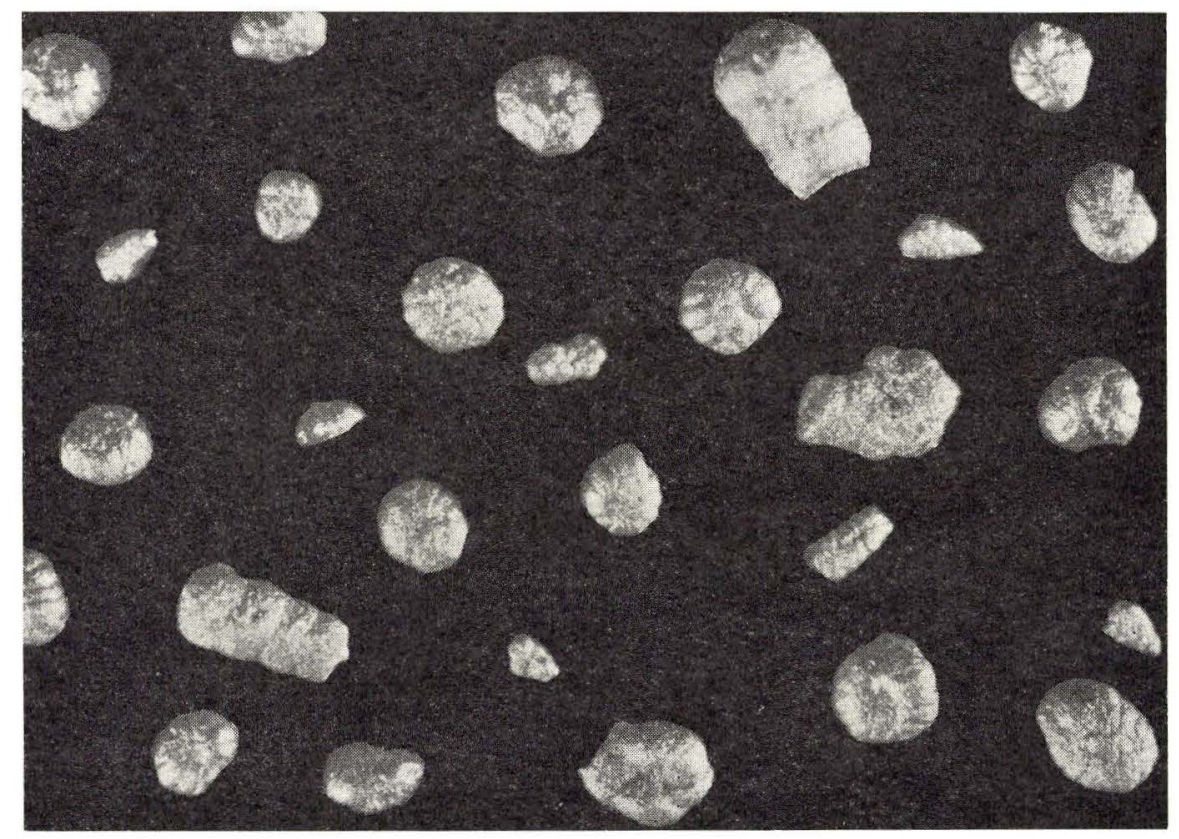

Section of the foraminiferal fauna from the depth $8260^{\prime}-8270^{\prime}$ (zone IV). $23 \mathrm{x}$. 


\section{INTRODUCTION}

The boring Ørslev No. 1, D.G.U. file No. 238.502, is situated in the island of Falster at the coordinates $54^{\circ} 46^{\prime} 55^{\prime \prime} \mathrm{N}$ and $11^{\circ} 59^{\prime} 02^{\prime \prime} \mathrm{E}$ of Greenwich (see text-figs. 1 and 2) and has been made in the period of November 1967 to January 1968 . The ground elevation is $+54^{\prime}(+16.4 \mathrm{~m})$ and the elevation of the Kelly Bushing is $+74^{\prime}(+22.7 \mathrm{~m})$. In this work all depths are given in terms of feet below the Kelly Bushing.

Below deposits of Zechstein age the boring has discloseci a series of about $750^{\prime}$ thickness of mainly reddish claystones, siltstones, and sandstones of undetermined age (Rotliegendes or Upper Carboniferous). Below these, from a depth of $6740^{\prime}$ to the final depth of the boring $8440^{\prime}$, are found highly fossiliferous beds of greyish claystones, marlstones and limestones. This series, from $6740^{\prime}$ to $8440^{\prime}$, is represented mainly by ditch samples, as only two sections have been cored, namely 6850'-6898' $6^{\prime \prime}$ (core No. 1) and 7686' $-7746^{\prime}$ (core No. 2). On the basis of the biostratigraphical data the series may be referred to the Lower Carboniferous. Since deposits of Carboniferous age hitherto have not been demonstrated in Denmark, this occurrence is of considerable interest for Danish geology, and already in January 1968 the core No. 2 was referred to the lowermost Visean by O. BRUUn CHRISTENSEN (unpublished reports, cf. 1971). In this preliminary study and determination the core has been correlated mainly with the German occurrences in Rügen.

In the present work the foraminiferal fauna is described. The foraminifera make up the dominating element in the usually rich microfaunas. Besides these the series contains varying amounts of ostracods, corals, crinoids, echinoids, brachiopods, gastropods, and pelecypods. Furthermore, among the plant fossils present FINN BERTELSEN will analyse the contents of spores from certain chosen sections. 


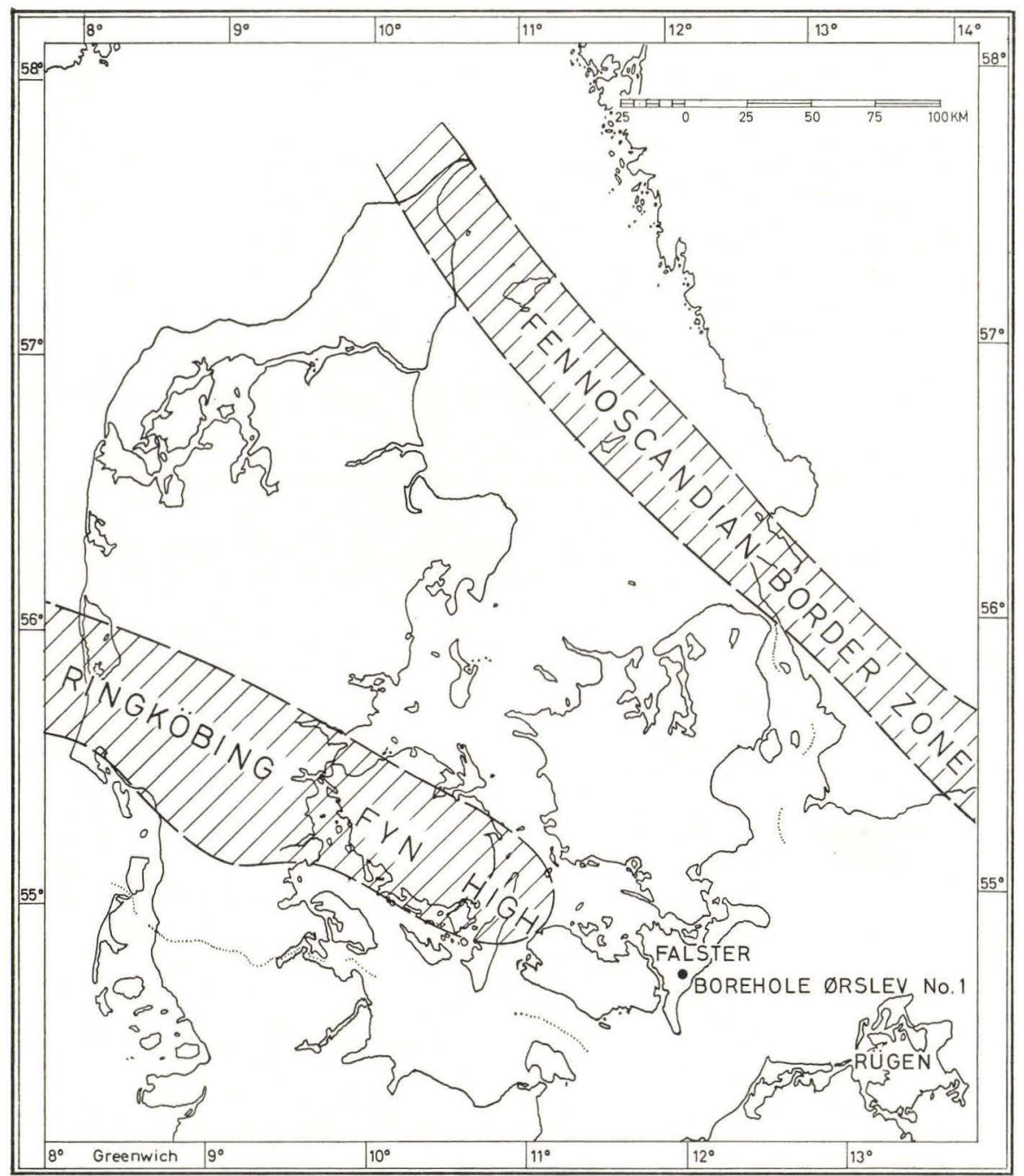

Text-fig 1: Map showing the location of the borehole Ørslev No. 1 . 


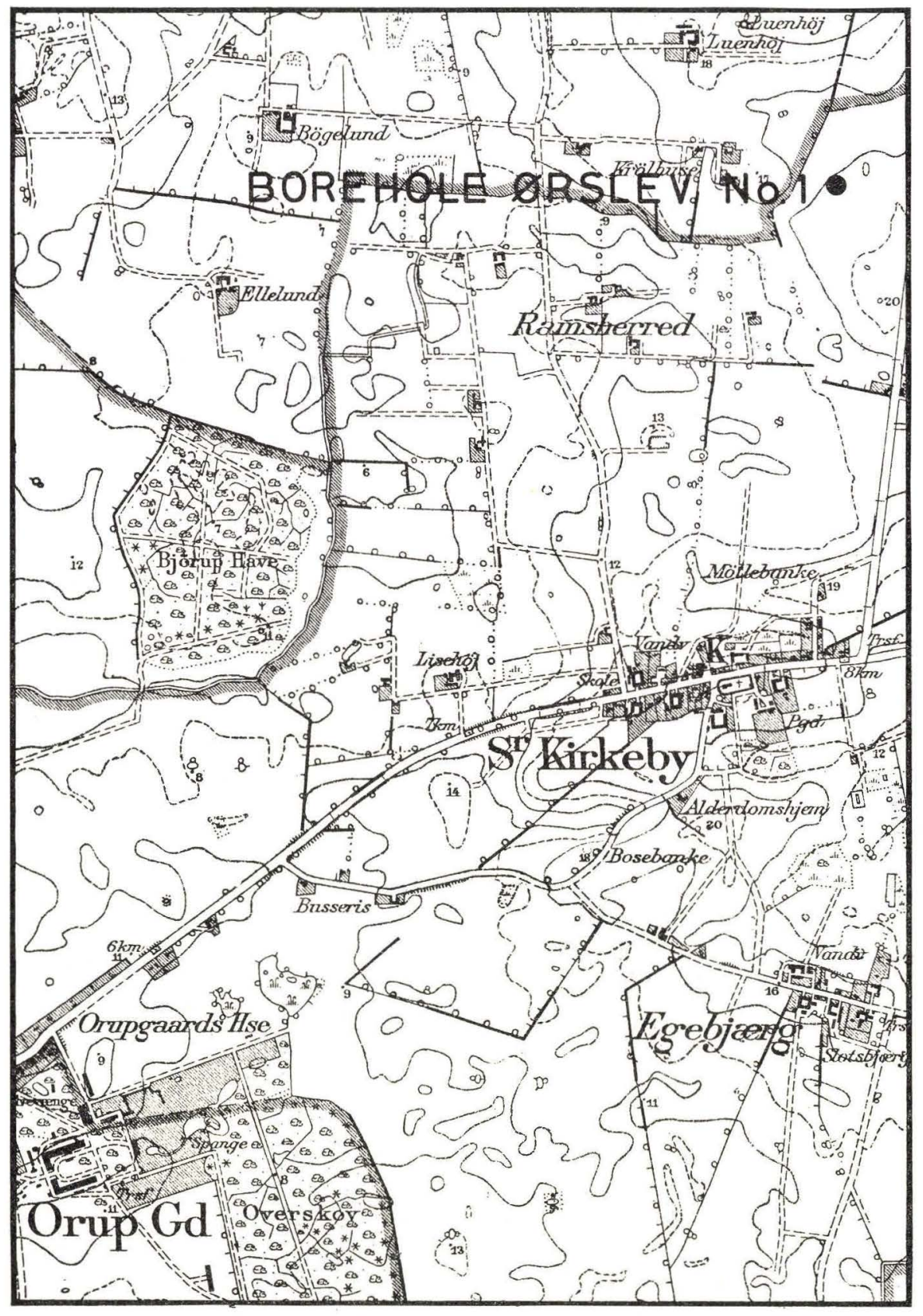

Text-fig. 2: Situation of the borehole $\emptyset$ rslev No. 1 (see text-fig. 1). Section of map sheet M 4526 in the scale 1:20 000. Copyright Geodetic Institute. 


\section{LITHOLOGY}

The sediments have been described by Th. ERIKSEn and E. Stenestad on the basis of dried cuttings, which have been separated from the original ditch samples by bringing them into suspension and decanting the boring mud. The lithologic description is also based on the cores Nos. 1 and 2 in the corresponding secticns. The description and zonation of the lithologic units given below have been corrected by means of the following Schlumberger Logs: Intervai Transit Time Log, Gamma Ray Log, Neutron Log, and Resistivity Log.

Description of the sediments in the section studied (cf. pl. XXII):

6740'-6770': Limestone (dolomitic), reddish-grey, and limestone, very argillaceous, dark brown.

6770'-6810': Limestone (dolomitic), light grey, with dark brown, argillaceous layers. The clay content seems to decrease upward.

6810'-6930': Limestone (dolomitic), greyish and brownish-grey.

6930'-7250': Marlstone, partly arenaceous, grey to dark grey. Lime content increasing upward.

7100'-7250': The above, alternating with sandstone, light grey and light reddish-grey, calcareous.

7250'-7280': Limestone (dolomitic), grey to light grey. In the middle of this section is found a thin zone of claystone, shaly, dark grey, calcareous.

7280'-7510': Limestone (dolomitic) and marlstone, grey to dark grey, alternating with sandstone, grey to light grey, very calcareous.

7510'-7650': Sandstone, grey to light grey, calcareous, alternating with limestone (dolomitic), dark grey. 7520'-7530': Oolitic limestone.

7650'-8057': Claystone (marlstone), grey to dark grey, and limestone, grey to dark grey.

8057'-8440': Limestone, grey to dark grey, with a little claystone (marlstone), grey to dark grey.

This series may be subdivided into three sections as follows: $6740^{\prime}-6930^{\prime}$, $6930^{\prime}-7650^{\prime}$, and $7650^{\prime}-8440^{\prime}$. 
In the uppermost of these sections, $6740^{\prime}-6930^{\prime}$, fairly massive limestones are found, apparentiy dolomitic, of varying colour. In a few intervals, 6740'$6770^{\prime}$ and about $6810^{\prime}$, there are smaller intercalations of an argillaceous, dark brown limestone. This section of limestones was probably deposited under fairly quiet and constant conditions.

A shortened version of O. BruUn Christensen \& E. Stenestad's description of core No. 1, which falls within this section (cf. Christensen, 1971):

Core No. 1, 6850'-6898'6":

Limestone, dolomitic, reddish-brown and greyish-brown, crystalline and hard. Bedding inclined $10^{\circ}-15^{\circ}$. Red and green lenses and spots are common. Stylolite-like structures occur. At $6854^{\prime} 6^{\prime \prime}$ and at $6868^{\prime}$ is found a cm-thick layer of a dark reddish-brown claystone. The limestone often has joints and slickensides, which often are filled with calcite. These features, in addition to deformed spots of iron oxide, indicate that some movement has taken place after the sedimentation.

A thin-section from $6861^{\prime} 5^{\prime \prime}$ (see pl. XX, fig. 3) confirms the above description of core No. 1.

It should be pointed out that the bedding inclination measured in core Nos. 1 and 2 cannot be considered to be the true dip, since the boring has been found to depart $6^{\circ}$ from the vertical at $7060^{\prime}$ and $31^{\circ}{ }^{\circ}$ at $7135^{\prime}$.

The midide section, $6930^{\prime}-7650^{\prime}$, is a rapidly alternating series of limestone, marlstone, claystone, and sandstone. Grey to dark grey marlstone is the dominating lithologic type in the interval 6930'-7250'; below 7100', however, it alternates with light grey and reddish-grey sandstone. In the interval $6930^{\prime}-7250^{\prime}$ the clay content shows an overall decrease upward. The interval $7250^{\prime}-7510^{\prime}$ is dominated by greyish (dolomitic) limestones with smaller intercalations of marlstone and sandstone. At about 7260'$7270^{\prime}$ is found a thin zone of silt-free, dark grey, calcareous claystone with plant fossils. The lowermost interval of the middle section, $7510^{\prime}-7650^{\prime}$, is a rapidly alternating series of sandstones, limestones and oolitic limestones. It is difficult to determine the thickness of the individual beds, but in the ditch samples the lithologic composition alternates at intervals of $20^{\prime}-30^{\prime}$. The deposition of this section must have taken place under fairly disturbed and changing conditions, which were probably due to tectonic movements in the regions. At least during two periods there was supplied coarse-grained material to the basin, as shown by the large number of intercalations of sandstone in the intervals $7100^{\prime}-7250^{\prime}$ and $7510^{\prime}-7650^{\prime}$. In addition to the conditions indicated by these sandstones and the marine limestones and marlstones, the dark grey claystone with plant fossils from the interval 7260' $-7270^{\prime}$ suggests the occurrence of a third type of conditions of deposition.

The lowermost of the three main sections, $7650^{\prime}-8440^{\prime}$, is fairly homo- 
geneous and consists of grey to dark grey limestone and claystone (marlstone). All transition forms between these two lithologic types are represented, as the limestone is often very argillaceous and the claystone very calcareous. The upper part of this series is characterized mainly by claystone (marlstone), while the lower part, below $8057^{\prime}$, is almost entirely made up of limestone. At about 7680' and 7740' traces of coal have been found. As the description of core No. 2 shows (see below), marine bea's alternate with non-calcareous, plant bearing beds. Bedding planes in the marine layers often show concentrations of macrofossils, which may be interpreted as material swept together by currents. This alternation between marine and brackish beds, which presumably characterizes the upper part $\left(7650^{\prime}-8057^{\prime}\right)$ of the section, is presumably paralic (cf. Christensen, 1971). Paralic facies are widely distributed in the Lower Carboniferous of Northern Europe. The lower part $\left(8057^{\prime}-8440^{\prime}\right)$ of the section seems to be characterized to a larger extent by marine deposits.

A shortened version of O. BruUn Christensen's description of core No. 2 is given (cf. Christensen, 1971):

Core No. 2, 7686'-7746':

7686'-7720': Claystone and shale, greyish-black and dark grey, very calcareous. Decimeter-thick beds of a hard, dark grey limestone with many brachiopod spines, corallites and rugose corals. Brachiopods are found in the entire section. Inclination of the strata $3^{\circ}-7^{\circ}$.

$7720^{\prime}-7727^{\prime}$ : Claystone, often slightly sandy, dark grey to greyishblack, non-calcareous, with pyrite and plant fossils.

7727'-7738': Claystone, in part shaly, in part hard and limestone-like, greyish-black, calcareous. Zones with fragments of corals, brachiopod spines, and crinoid stalks.

$7738^{\prime}-7743^{\prime} 6^{\prime \prime}$ : Shale, often somewhat fissile, greyish-black, calcareous, with pyrite. Smaller intervals with fragments of corals and brachiopod spines and shells. At 7739'6" a large coalified plant fossil.

$7743^{\prime} 6^{\prime \prime}-7745^{\prime} 6^{\prime \prime}$ : Claystone, somewhat shaly, but mainly massive and calcareous, greyish-black. Only few plant fossils. Contains pyrite. Thin, light grey bands with rugose corals and brachiopod spines. Inclination of layers $3^{\circ}-5^{\circ}$.

Thin-sections have been made of the sediments of core No. 2 at the following

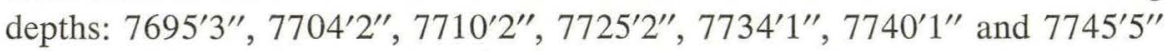
(cf. pl. XXI, figs. 1-2). In all of these thin-sections, with the exception of the one from $7725^{\prime} 2^{\prime \prime}$, the rock must be classified as marlstone, often with a fairly large content of quartz. The carbonate occurs in the form of welldefined grains in the silt fraction, embedded in a matrix of clay minerals and some organic matter. As a result of this texture, the rock appears to be very 
dark and fairly soft, so that in macroscopic view it might be interpreted as a very calcareous claystone. The thin-section from $7725^{\prime} 2^{\prime \prime}$ is predominantly quartz silt, with a small content of clay minerals and carbonate. It would be incorrect to draw conclusions concerning the entire section, 7650'-8440', from these thin-sections, but it seems reasonable to assume that the large clay content, especially in the section above $8057^{\prime}$, may be due to marlstone of the above-mentioned type.

It should be mentioned that the limestones in the entire series studied are more or less dolomitic. Solution in a $10 \% \mathrm{HCl}$ takes place slowly, often even if under heating. 


\section{MATERIALS AND METHODS}

As mentioned above, the largest part of the series here examined has been drilled without coring, only the two sections $6850^{\prime}-6898^{\prime} 6^{\prime \prime}$ and $7686^{\prime}-7746^{\prime}$ being cored. In the sections drilled without coring, ditch samples have been taken at 10 feet intervals during the boring. After disintegration by means of petrol and boiling water, the ditch samples have been washed on a sieve with $0.1 \mathrm{~mm}$ apertures. The core samples have, after a gentle crushing, received the same treatment. The crushing of the rocks by the rotary bit to cuttings of 1-2 $\mathrm{mm}$ size has made it easy by this method of treatment to liberate a fairly large number of microfossils from the often fairly hard rock types. 59 ditch samples and 7 samples from the cores have been selected for study of the foraminiferal fauna. From the seven core samples and from about two ditch samples from each $100^{\prime}$ interval all foraminifera are picked out, so that the entire fauna is represented in the corresponding slides. In order that also the more rare foraminifera may be described, selected species have been picked out from the other (26) ditch samples. The two ways of picking out the foraminifera are indicated for the respective samples in plate XXII.

Nine thin-sections have been made from the core samples (see p. 13 and 14) to show the lithology and the number of fossils per unit area. The thinsections from core No. 2 agree well with the results got from the sifted residues of core samples and ditch samples, while the thin-section from core No. 1 shows an unexpectedly large number of fossils per unit area and number of species. This shows that in work with ditch samples of hard limestones the evaluation of the faunas should be made with a certain caution, since the above-mentioned methods of treating the samples do not always suffice to liberate the microfossils.

Thin-sections of foraminifera have been made in the following way: A single test is embedded in the synthetic resin Lakeside. It is then ground under a microscope by means of a glass plate whose surface has been roughened by treatment with carborundum powder. Since the grinding fluid is water, the entire process of grinding may be observed in the microscope, and all the details of the entire test are clearly visible. The Lakeside may be reheated to its melting point one or more times, so that the test may be turned to the position desired. For the study here presented, 321 thin-sections of this kind have been made. 
For the study of the arrangement of the chambers in Palaeospiroplectammina diversa and »Palaeospiroplectammina mellina, fluorite preparations of single tests have been made by the following method: The test lies in a $40 \%$ hydrofluoric acid for two weeks, whereby the wall is transformed into fluorite. Then it is washed in alcohol and embedded in glycerine jelly. By ihis treatment the wall becomes so translucent that the brown films covering its inner side may be seen, whereby it is possible to discern the relative position of the chambers. Unfortunately it has been found impossible to produce usable photographs of such preparations. 


\section{THE FORAMINIFERAL FAUNAS}

The foraminifera of the series studied represent 48 forms, of which only 13 are determined to species. Of the remaining forms, nine are determined with some uncertainty and four are established as new ones. The rest are given with open nomenclature.

As shown in plate XXII the series is divided into four faunizones named I-IV (youngest-oldest). This zonation is to be considered primarily as a practical way of describing the fauna, since the vertical extent of each zone cannot be definitely determined. In judging a material taken from ditch samples it must be recognized that there is no certainty that the microfossils come from the depth at which they are found. During the drilling there is always a possibility of caving from any of the layers between the level of sampling and the bottom of the casing. In the boring Ørslev No. 1 the last casing has been set at 5994'. Thus it is possible to have cavings from the entire section below this depth. For ditch samples representing less highly consolidated rocks the highest level at which the microfossils are found may in general be considered to be their upper limit in the series, while such a demarcation is uncertain for the case of ditch samples of limestones that are as hard as the ones in the interval 6740'-6930' (see p. 16). Because of these two sources of error, a statement of the quantitative distribution of the individual forms is thought to be without meaning, and therefore their occurrence is shown in plate XXII only by a "+". In a subsequent evaluation of the material examined the amount of cavings is tentatively estimated on the basis of the relative frequency of the individual species and the character of the sediment possibly remaining on the tests.

Zone I: This zone comprises samples Nos. 2-7 $\left(6740^{\prime}-6945^{\prime}\right)$. The extent of the zone corresponds very closely to the sequence of the massive, dolomitic limestones in the upper part of the series; however, sample No. 7 is located just below the lower limit of the limestone.

The fauna is dominated and characterized by forms belonging to the family Ozawainellidae, namely Endostafella? sp. 1 and 2. The genus Endothyra is represented by such species as Endothyra sp. (F-13), E. aff. costifera, E. sp. 5, E. cf. delepinei, E. convexa regularis and E. sp. 1 (?), of which the latter three are found in the lowermost part of the zone only. Endothyra sp. (F-13) and E. sp. 5 are common, while the other species of 
Endothyra are only infrequently represented. Of Tetrataxis cf. pressulus there have been found only two specimens, namely in sample No. 7. Likewise Brunsiina spirillinoides is represented by two specimens, one in each of samples Nos. 4 and 7. In a thin-section of the rock from core No. 1, 6861'5" (sample No. 4), a few specimens of Brunsiina pseudopulchra, "Palaeospiroplectammina" mellina, Palaeospiroplectammina venusta, P. aff. tchernyshinensis and Endothyra aff. costifera have been seen.

The foraminifera of zone I are fairly poorly preserved and are not particularly abundantly represented in the ditch samples. However, the abovementioned thin-section (see plate XX, fig. 3) shows that the number of fossils per unit area may be large in the rocks of this zone. Thus the fauna from the ditch samples is not representative but must be evaluated in conjunction with the fauna of the thin-section.

Zone II: This zone comprises samples Nos. 8-29 (6945'-7695'), which are taken from the alternating series of limestone, marlstone, and sandstone. The samples are usually very poor in fossils, so that many species occur with only a single specimen in the sample. A few samples, such as Nos. 20, 23, and 25 , are completely without fossils. The foraminifera often are very poorly preserved, especially in the samples Nos. 13-15.

The upper boundary of this zone is placed where Palaeospiroplectammina diversa has its uppermost occurrence. Immediately below this level the number of those forms which occur in the above-lying section, and the number of specimens of each of these forms, show a decline. This decline is an evidence that their occurrence is due to caving. On the basis of this it is assumed that zones I and II have only a very small number of species in common. Endothyra cf. delepinei, E. sp. 1 and "Palaeospiroplectammina" mellina show so clear an increase downward in zone II that they must be considered to belong to zone II also. Tetrataxis cf. pressulus occurs in such a small number that it cannot with certainty be placed, but it is assumed also to occur in zone II as well as in zone III (?) and IV. The other forms from zone I (with the exception of Brunsiina spirillinoides, which also occurs in zone III and IV) must be limited to this zone. Their occurrence in the samples below zone I is interpreted as due to caving.

Of Palaeospiroplectammina diversa there is found three specimens, distributed in the two uppermost samples, Nos. 8 and 9. "Palaeospiroplectammina" mellina occurs in almost all the samples below this level and is there often the dominant form. Apart from these two, zone II is characterized by the genus Endothyra: $E$. cf. delepinei is found in the upper part of the zone, $E$. sp. 1 occurs scattered throughout the entire zone, E. cf. apposita and $E$. sp. 2 occur in the middle part of the zone, and the lower part of the zone is characterized by E. danica, E. spp. (F-29 \& F-44), E. michoti spinata and E. aff. prisca. Except for Endothyra sp. 2, each of the species of Endothyra is represented with but a few specimens in each sample. However, sample 
No. 29 contains a larger number of Endothyra danica, E. michoti spinata and "Palaeospiroplectammina" mellina, whereby it shows closer similarity to sample No. 30 (zone III) than to the samples from zone II. The family Ozawainellidae is represented only by Eostaffella sp. 1, of which there are only six specimens, all from sample No. 28. Finally there are found a few specimens of Pseudolituotubella sp. 2 (?) and 3 in samples Nos. 17 and 28 (?). Endothyra recta, a species which is particularly characteristic of zone IV, occurs possibly in zone II. It is very doubtfully determined in samples Nos. 19 and 28. The specimen in the first sample seems to show affinity to both E. recta and E. sp. 4.

Zone III: This zone comprises samples Nos. 30-48 $\left(7695^{\prime}-8180^{\prime}\right)$, all of which are taken in the upper part of the homogeneous series, with grey to dark grey limestones and claystones. The samples of zone III, especially samples Nos. 30-41, contain many very well-preserved foraminifera.

There seems to be a fairly large number of species in common between zone II and III, in that almost every species from zone II is represented in zone III with a relatively large number of individuals. The upper boundary of zone III is based on the uppermost occurrence of such forms as Endothyra spp. (F-37) and $E$. cf. bradyi, and on the very numerous representation of "Palaeospiroplectammina" mellina and Endothyra michoti spinata, which e.g. in sample No. 30 make up about $32 \%$ and about $66 \%$ of the fauna, respectively. In zone III the number of species and the number of individuals are large, and all the specimens are well-preserved and distinct, whereas in zone II the fauna is poor in species as well as in individuals, and the tests are usually poorly preserved.

The fauna of zone III is in the upper part characterized by "Palaeospiroplectammina" mellina, Endothyra danica and E. michoti spinata, while the lower part is dominated and characterized by E. cf. bradyi. Endothyra danica and $E$. michoti spinata decrease so rapidly in frequency below sample No. 36 that their occurrence there is presumed to be due to caving. Besides these three species, the genus Endothyra is in zone III represented by a more or less scattered occurrence of E. sp. 1, E. cf. apposita, E. aff. prisca, E. recta, E. spp. (F-37) and E. sp. 3. Among other species present in the zone may be mentioned Earlandia elegans, Palaeospiroplectammina diversa, Lituotubella glomospiroides minima, Pseudolituotubella sp. 2 and 3, Pseudolit. aff. tenuissima, Septatournayella pseudocamerata, Tetrataxis cf. pusillus, $T$. sp. 2, Conilites dinantii and Haplophragmina loeblichi. All of these forms occur scattered and with but few specimens. This large number of species is found at two levels especially, namely in sample No. 30, taken from a zone of claystone (marlstone) in core No. 2, and samples Nos. 36-39. The other sections are not so rich in species but contain mainly the above-mentioned characteristic forms. 
Zone IV: This zone comprises samples Nos. 49-66 (8180'-8440'), which are taken in the lower part of the series, dominated by dark grey limestone. All the samples from this zone contain a large number of well-preserved foraminifera. The number of species is very large relative to the number of specimens in each sample. This may possibly be due to caving from zone III. Only Endothyra danica and E. michoti spinata have decreased so much in number that their presence in zone IV must be due to caving. The other forms which this zone has in common with zone III occur so regularly that it is fully justified to consider them to be primary.

Besides such species as are also present in zone III, zone IV contains a number of species which are not known from the other zones. Thus the uppermost occurrence of Septabrunsiina spissusvoluta determines the upper boundary of zone IV. The zone is characterized by Endothyra recta, which occurs scattered in zone III but is dominant in zone IV. Besides by this species, the genus Endothyra is represented by the same species as in zone III and by $E$. sp. 4, which is very closely related to E. recta. The faunal element which distinguishes zone IV from zone III is made up of a number of species represented by only a few specimens each, namely Brunsiina pseudopulchra, Septabrunsiina spissusvoluta, Palaeospiroplectammina venusta, $P$. aff. tchernyshinensis, Endothyra sp. 6, Paraendothyra cummingsi, P. nalivkini, Pseudolituotubella sp. 1 and Tetrataxis sp. 1. Palaeospiroplectammina venusta occurs possibly also in zone III, since in samples Nos. 34 and 38 there are found a couple of fragments of the biserial part. The determination is, however, so uncertain that these finds cannot be used here. Furthermore, Palaeospiroplectammina venusta, $P$. aff. tchernyshinensis and Brunsiina pseudopulchra are found in zone I (sample No. 4).

The above exposition of faunizones I-IV shows that zone I differs considerably from the other three zones. Its fauna differs so much from the others that it can be considered as a separate stratigraphic unit. On the basis of the faunal data its upper boundary must lie between samples Nos. 1 and 2, while on the basis of the lithology it would be natural to place the boundary immediately above sample No. 1, at 6740'. Sample No. 1 contains so large amounts of cavings from the overlying reddish claystones and sandstones that this would give a reasonable explanation of the missing fossils.

Zone II, III and IV differ from one another mainly in the downwards increasing number of species. This increase seems, when considered in conjunction with the lithology, to be a function more of the environment than of the boring method used, in which the samples are liable to be contaminated by cavings. Species such as "Palaeospiroplectammina" mellina and Palaeospiroplectammina diversa are forms which are evenly distributed in all three zones. The genus Endothyra is prominent throughout the entire series and is represented by forms only a few of which are limited to single 
zones. A prominent group of forms, showing affinity to E. bradyi, is here represented by the forms $E$. cf. apposita, E. cf. bradyi, E. sp. 1 and $E$. sp. 2 . Except for the first-mentioned of these, they are defined on the basis of the external morphology of the tests (see p. 30), while their internal characters point toward different species and varieties as e.g. E. apposita, E. bradyi obsoleta, E. delepinei, E. volynica, E. phrissa and E. omphalota. 


\section{STRATIGRAPHICAL ANALYSIS}

\section{Introduction.}

The series studiec', 6740'-8440' in the boring Ørslev No. 1, was deposited in the Palaeozoic. It is situated below beds of the Zechstein, and an analysis of its foraminiferal faunas shows that it belongs to the Lower Carboniferous. The foraminifera represent a number of genera, which have the following stratigraphical distribution:

Earlandia
T'etrataxis
Brunsiina
Lituotubella
Palaeospiroplectammina
Pseudolituotubella
Septabrunsiina
Septatournayella
Endothyra
Paraendothyra
Haplophragmina

\author{
Devonian-Carboniferous \\ Carboniferous-Triassic \\ Upper Devonian-Lower Carboniferous \\ Lower Carboniferous \\ Lower Carboniferous \\ Lower Carboniferous \\ Upper Devonian-Lower Carboniferous \\ Upper Devonian-Lower Carboniferous \\ Upper Devonian?, Carboniferous-Permian \\ Lower Carboniferous \\ Lower Carboniferous
}

The pronounced dominance of Endothyra in conjunction with the frequent occurrence of Lituotubella, Palaeospiroplectammina and Pseudolituotubella in the larger part of the series $\left(6945^{\prime}-8440^{\prime}\right)$ shows that it belongs to the Lower Carboniferous. The uppermost part of the series $\left(6740^{\prime}-6945^{\prime}\right)$ is dominated by forms which are classed with the Ozawainellidae. This family is known from the Carboniferous and the Permian. Because of the occurrence of among others the genera Brunsiina and Palaeospiroplectammina, also this section must be placed in the Lower Carboniferous.

The boring Ørslev No. 1 is situated in the northern part of the Lower Carboniferous basin region in Northern Europe. The beds and foraminiferal faunas studied are in the following correlated with two regions from which foraminiferal faunas are described, namely Belgium and Rügen. Correlation is also made with the Russian part of the basin, whereas the data available have not allowed a correlation with the English part. 


\section{Correlation with Belgium.}

The Lower Carboniferous deposits in Belgium, where the type localities for the chronostratigraphic units Tournaisian and Visean are located, are among the best described deposits of the Lower Carboniferous in Western Europe. The foraminiferal faunas are described in detail by ConIL (1963), ConIL \& Lys (1964, 1965, 1966, 1967 and 1968) and FrANSSEN (1967), and consequently a correlation with these deposits is natural.

The dominance of Ozawainellidae in zone I and its occurrence lowermost in zone II suggests an increase of the share of this family in the fauna of the deposits studied. In the Belgian deposits Ozawainellidae occurs the first time in the lowermost Visean (1a) and is common in Visean $1 \mathrm{~b}$ and 2 (ConIL \& LYs, 1964, 1966, and 1968). The genus Endothyra, which is dominant in zone II, III, and IV and is common in zone I, is represented by a number of forms which may be compared with species from Tournaisian 3 and Visean. Endothyra cf. apposita, E. sp. 1, E. sp. 2 and E. cf. bradyi, which characterize zone II and III, seem to be comparable with the corresponding species from Lower and Middle Visean. E. michoti spinata from zone II and III is very closely related to $E$. michoti, which is known only from Visean 1a. E. recta, which dominates in zone IV and occurs in zone III, is common in Visean 1a and rare in Visean 2b. E. apposita (E. cf. apposita) and E. delepinei (E. cf. delepinei) are both known from the Belgian Upper and Middle Visean. It thus seems possible to parallel the successive occurrences of the above-mentioned species of Endothyra in the series studied with their occurrences in the Belgian Visean.

"Palaeospiroplectammina" mellina, Palaeospiroplectammina diversa, $P$. venusta, Conilites dinantii and the genus Tetrataxis are in the Belgian deposits known from Tournaisian 3 and Visean 1 and in the case of a very few of these forms also from Visean 2 and 3. Brunsiina pseudopulchra and $B$. spirillinoides occur in the entire Visean, and Paraendothyra cummingsi is limited to Visean 1.

The above-mentioned data show that the series in the boring $\emptyset$ rslev No. 1 must be compared with certain parts of the Belgian Visean. The occurrence of Endothyra recta, Paraendothyra cummingsi and Palaeospiroplectammina venusta in zone IV makes probable a correlation with Visean 1, perhaps Visean 1a. Also zone II and III, which contain Palaeospiroplectammina diversa and Endothyra michoti spinata, probably should be correlated with Visean 1; especially the very pronounced dominance of the latter subspecies in sample No. 30 and the occurrence of Ozawainellidae in sample No. 28 point in this direction. The dominance of Ozawainellidae in zone I together with among other things the occurrence of Endothyra cf. delepinei may indicate that this zone should not be correlated with Visean 1 but possibly with Visean 2. 
If the above-mentioned correlation is correct, the faunas examined lack a significant element, namely the family Archaediscidae. This family is in the Belgian deposits a very important one in the Visean (ConIL \& Lys, 1964 and 1968). The absence of this family is probably due to differences in facies, since the sediments studied must be classified as in the main littoral, paralic facies.

\section{Correlation with Rügen.}

As a result of borings in the German island Rügen, deposits of Lower Carboniferous age have been found a few years ago. A preliminary report (KNÜPFER \& WEYER, 1967) gives a short description of the sediments and a summary of the fossils found. Neither the faunas nor the individual fossils are described. Nevertheless, because of the geographic location of Rügen a comparison with these deposits is important.

Among species common to the boring Ørslev No. 1 and the borings in Rügen may be mentioned Endothyra recta, which in the latter locality is found in a series of limestone and claystone which on the basis of biostratigraphical data is referred to the lowermost Lower Visean, and Palaeospiroplectammina diversa, which is found in marlstone and limestone referred to Upper Visean. Finally Palaeospiroplectammina tchernyshinensis is found in claystone and marlstone from Tournaisian and in the beds referred to the lowermost Lower Visean. In the last-named beds also Endothyra michoti is found. The occurrence of Palaeospiroplectammina diversa in beds which may be referred to Upper Visean is anomalous for this species, as it in both the U.S.S.R. and Belgium is known only from Upper Tournaisian and Lower Visean. The occurrence of the other three species in Rügen, on the other hand, is in agreement with their occurrence in the boring Ørslev No. 1 when the deposits found in this boring are tentatively correlated with the Belgian deposits in the manner described above. A further confirmation of this is the fact that the family Ozawainellidae in Rügen occurs in the limestones referred to the uppermost Lower Visean and Middle Visean and the beds referred to Upper Visean. Finally it may be mentioned that the family Archaediscidae is found only in beds referred to Upper Visean.

As seen above, the basis for a correlation with the deposits in Rügen is very weak. There is some similarity between zone III and IV and the about $400 \mathrm{~m}$ thick series of limestone with a few intercalations of claystone which is referred to the lowermost Lower Visean. The sediments show the same character, and the two important forms Endothyra recta and E. michoti (spinata) are found in both localities. Zone I and II may perhaps be compared with the about $250 \mathrm{~m}$ thick series of massive limestones which is referred to the uppermost Lower Visean and Middle Visean, but their faunas have very little in common, namely the occurrence of Ozawainellidae in 
these beds and its absence from the underlying ones. A very sandy series as the one found in zone II is apparently unknown in Rügen. On the basis of our present knowledge about the deposits in Rügen the correlation here outlined must be correct. Final conclusions cannot be drawn until more detailed descriptions of the faunas and the sediments are published.

\section{Correlation with the U.S.S.R.}

Because of the scanty literature available for the present author, correlation with the Russian deposits is somewhat difficult. For the purposes of the present work, descriptions of species established in the U.S.S.R. are taken from Ellis \& Messina (1940 ff.), while data on stratigraphic distribution, faunal composition etc. are taken mainly from the West-European literature. However, some Russian literature, belonging to R. ConIL, has been used too. On account of the large similarities of fauna between the Russian and the Belgian deposits it is natural to consider the series examined as a connecting link which has relations to both sides.

In analogy with the development in the Belgian deposits, Ozawainellidae and Archaediscidae occur lowermost in the Visean, in the Stalinogorsk Horizon, and make up an essential part of the fauna in the Visean (cf. ConIL, 1963 and MAMET, 1965). Endothyra recta (zone III and especially zone IV) is in the U.S.S.R. known only from deposits referred to Upper Tournaisian and Lower Visean, while E. convexa regularis is an important form in Middle Visean. Such species as Earlandia elegans, Brunsiina pseudopulchra, $B$. spirillinoides, Palaeospiroplectammina diversa, $P$. venusta, and Septatournayella pseudocamerata are all known from Upper Tournaisian and Lower Visean. "Palaeospiroplectammina" mellina is known only from Lower Visean, and Paraendothyra nalivkini is known from Middle Tournaisian.

Some of the above-mentioned species, which in the U.S.S.R. are known from both Upper Tournaisian and Lower Visean, occur in the Belgian deposits only in the Visean, which fact is thought to be due to an interruption of the connection between the two basin regions during certain intervals of Upper Tournaisian (cf. ConIL \& LyS, 1968). The presence of Endothyra convexa regularis in zone I supports the above-mentioned supposition that this zone correlates with Middle Visean. Among the other species named only Paraendothyra nalivkini brings in something new relative to what the correlation with Belgium shows. This species is not known in Western Europe and has not previously been found together with Paraendothyra cummingsi. The occurrence of $P$. nalivkini together with Palaeospiroplectammina aff. tchernyshinensis in zone IV might suggest a possible correlation with Tournaisian (Upper-Middle), but since the fauna in this zone in all other respects is a Visean fauna, characterized by Endothyra recta, this possibility seems to be ruled out. 
Correlation with North America.

The biostratigraphical subdivision of Lower Carboniferous in North America is to a large extent based upon the phylogenetic evolution of the endothyroid foraminifera (J. E. Zeller, 1950 \& 1957; D. E. N. Zeller, 1953; WoodLAND, 1958; McKay \& Green, 1963). On the basis of this it is possible to give a fairly detailed division into zones, which, however, cannot in every instance be correlated with certainty between the various regions within North America where Lower Carboniferous is represented. Correlation with the Eurasian deposits seems possible especially for the western regions of North America.

As may be seen from the above exposition of the four faunizones in the boring Ørslev No. 1, the deposits contain no or only slight suggestions of a phylogenetic evolution within the genus Endothyra. Forms with many whorls, many chambers in each whorl, and thin ridges (E. recta) are dominant in the lowermost part of the series, in zone IV, and occur in zone I, II, and III (E. aff. costifera). Zone II and III are characterized by forms with few whorls, few chambers in each whorl and thick ridges (the group $E$. cf. bradyi), and at the transition between the two zones by the planispiral form $E$. michoti spinata. Zone II and III are further characterized by $E$. danica, which resembles the group $E$. cf. bradyi but lacks internal elements. Zone II and III with the group E. cf. bradyi and the planispiral form may perhaps be compared with deposits from the Meramecian, among others the Salem Formation (E. J. Zeller, 1950). E. michoti spinata shows, however, so close a similarity to $E$. tumula that correlation might also here be a possibility. The E. tumula Zone is with some uncertainty referred to the Osagian (E. J. Zeller, 1957), and is in a few cases even referred to a subzone of the Granuliferella Zone (McKay \& GreEN, 1963). E. cf. delepinei, which is found in zone I and II, has very strongly developed internal elements, and in this it shows some resemblance to certain forms from the uppermost Meramecian and the Chesterian. This resemblance of the series from $\emptyset \mathrm{rslev}$ No. 1 to the North American deposits from the Osagian and Meramecian is, however, so slight that it cannot form a basis for more unambiguous conclusions.

\section{Conclusion.}

The biostratigraphical data of the series from the boring Ørslev No. 1 show greatest agreement with the Belgian deposits. On the basis of this agreement the entire series may be correlated with certain parts of the Visean (see text-fig. 3). Zone II, III and IV, which are characterized by Palaeospiroplectammina diversa and the genus Endothyra, undoubtedly correlate with Lower Visean (Visean 1). The occurrence of Endothyra recta and Paraendothyra 
CHRONOSTRATIGRAPHICAL CORRELATION

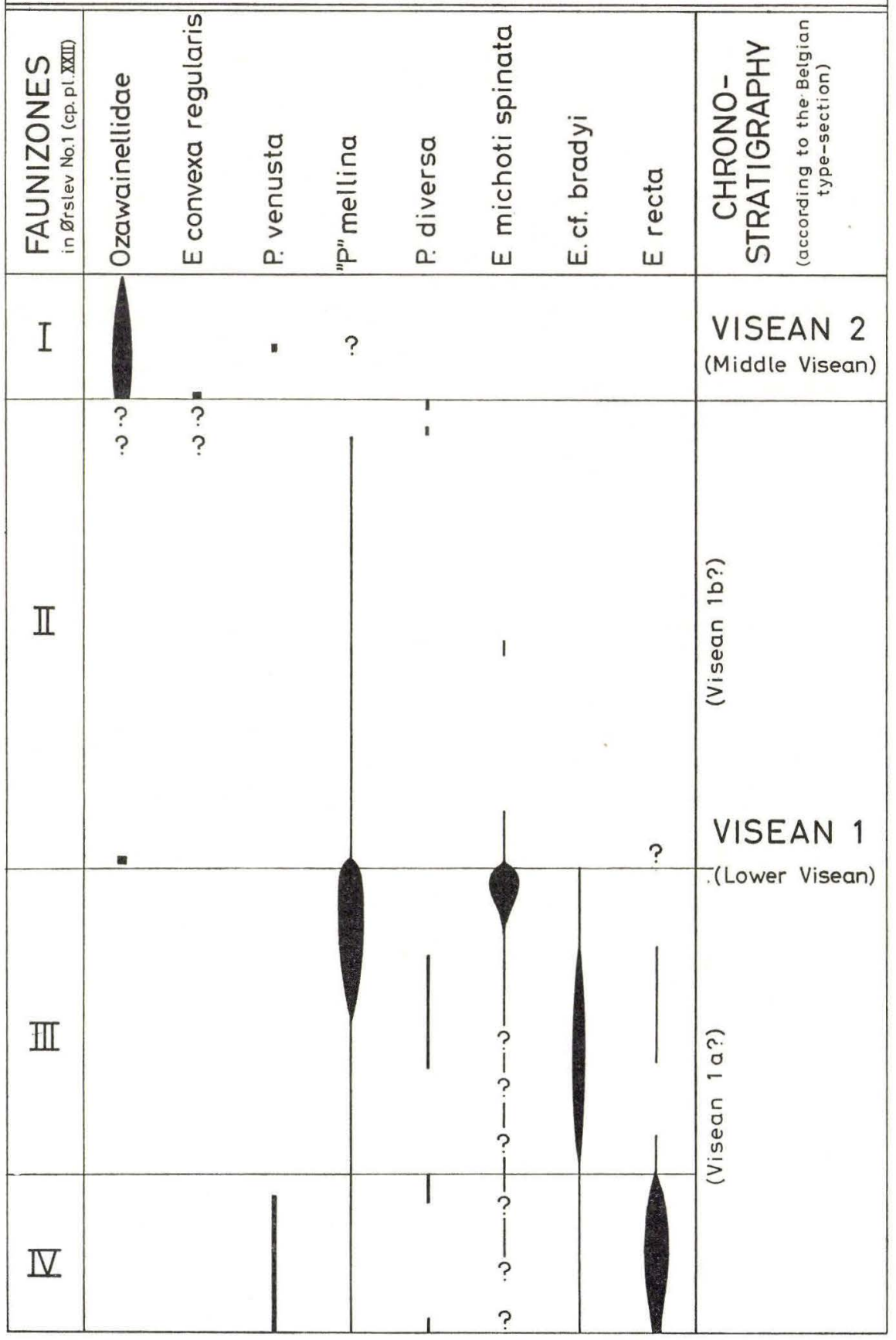

Text-fig. 3 . 
cummingsi in zone IV and Endothyra michoti spinata in zone III may indicate a parallel to Visean 1a. The pronounced dominance of Ozawainellidae and the presence of Endothyra convexa regularis in zone I suggests that it is younger than Visean 1. It is here presumed to correlate with Middle Visean (Visean 2).

Since most of the samples are taken as ditch samples, it is not possible on the basis of the fossils to determine with certainty the uppermost boundary of the fossiliferous Carboniferous deposits in the boring Ørslev No. 1. The Schlumberger Logs show a fairly uniform series in the interval 6740'-6930'. This fact, taken together with the foraminiferal fauna described, is the basis for placing the section $6740^{\prime}-8440^{\prime}$ in the Visean.

It is also not possible to determine the boundaries between the four faunizones with any certainty, as all three boundaries fall within intervals that have not been cored. The boundary between zone I and II is placed between a sample dominated by Ozawainellidae and $E$. convexa regularis (sample No. 7) and a sample with Palaeospiroplectammina diversa (sample No. 8). Thus the boundary between these two zones is placed at 6945'. The series $6740^{\prime}-6945^{\prime}$ is with some uncertainty referred to Middle Visean (Visean 2), while the series $6945^{\prime}-8440^{\prime}$ is referred to Lower Visean (Visean 1).

These deposits should be considered in relation to the extensive deposits of shelf limestone in Northern Europe (cf. Bartenstein, 1968). At the transition between Tournaisian and Visean an extensive transgression began in the Variscian geosynclinal region. The description and the biostratigraphical analysis of the series in the boring Ørslev No. 1 shows that this transgression reached at least as far as the southern part of Denmark. A comparison with the deposits in Rügen (KNÜPFER \& WEYER, 1967) shows that the conditions of sedimentation were less stable in the southern part of Denmark, in that in certain periods relatively large amounts of coarse material were supplied to the area. This is presumably due to a more littoral situation of the area. 


\section{PALAEONTOLOGICAL PART}

\section{Introduction.}

Among the foraminifera picked out from the various samples there are some specimens whose state of preservation is so poor that they are not considered usable in the present study. Since the material examined is thus selected from the total material, none of the samples may be considered to be quantitative, and therefore the number of specimens of each species in the individual samples is not given. The present author estimates, however, that all the species present are still represented in that part of each sample which is left for study after the specimens of too poor a state of preservation have been excluded.

In the stuady of foraminiferal faunas of Palaeozoic deposits it is, among other places in the U.S.S.R. and in Belgium, common practice that the determination of the individual specimens is done by means of thin-sections of the rock. In such thin-sections the orientation of the foraminifera is more or less random, and a study of their external morphology is not possible. Cummings (1958 \& 1961) points out that descriptions of morphospecies from such thin-sections and the biostratigraphical conclusions derived from these may give rise to errors. According to him, an evaluation based on both the external morphology of the tests and their internal structures must be of value. However, Palaeozoic rocks often are so consolidated that it is not possible to liberate entire tests, so that thin-sections of the rock is the only means available for the study of the microfaunas. In the present study it has to a very large extent been possible by simple methods to separate a large number of tests for the examination of the foraminiferal fauna. The morphospecies are in this study preliminarily determined on the basis of the external morphology of the tests, while the internal structures have been used in the determination to species, in that all the relevant descriptions, from the Belgian and Russian studies, are based exclusively upon thin-sections. The combination of the two methods of analysis, namely study of the external morphology and study of the internal characters, has in the main given results comparable to the published descriptions based on thin-sections. However, in a few cases within the genus Endothyra some difficulties have been met with. Thus within the group comprising $E$. cf. apposita, E. cf. bradyi, E. sp. 1 and E. sp. 2 the determination is uncertain. E. cf. apposita 
is represented by two specimens which on the basis of the internal elements are separated from two of the other three morphospecies. With the exception of these two, all the specimens from this group are retained in the three forms on the basis of the external morphology. In thin-section, however, they show affinity to a number of species and varieties (see p. 22 and 53). Because of lacking qualifications and prerequisites for making a possible revision, this group of specimens are described as the three morphospecies with open nomenclature rather than the individual specimens being referred to known species and varieties and thereby giving occasion for reflections on the biostratigraphical relations. In order to further emphasize the importance of a combination of the two methods of analysis mentioned, the present author wishes to refer to the description of Endothyra michoti spinata (see p. 59). A valuable analysis of this form is possible only by means of studies of both the external morphology and defined thin-sections.

In all the forms described below, the wall consists of calcium carbonate. This determination is made by solution in a $10 \%$ hydrochloric acid and by noting that the refractive indices of the material is low. Within the chambers a film is often found which is indissoluble in hydrochloric acid. It is thought to be of organic origin and usually has no direct contact with the wall. Since it forms an uninterrupted covering of the inner surface of the chambers, it clearly reveals the distribution of the chambers, especially in the initial part. This film is usually present in specimens from the lower part of the section, $7650^{\prime}-8440^{\prime}$. The microstructure of the wall is in almost all cases uniformly granular. In Lituotubella and Pseudolituotubella the wall contains inclusions of larger grains. Multiple layers in the wall, as described for Palaeotextularia and Plectogyra (among other places in Cummings, 1956 and E. J. ZELLER, 1950), are in no case observed in the present material.

\section{Description of the Foraminifera.}

Under the heading "Material" is given the number of specimens upon which the description is based. Also the number of thin-sections and of fluorite preparations are given.

The diagnosis comprises the characters necessary and sufficient for the determination of the form in question.

The description is divided into two sections, the first of which covering the external morphology of the tests, and the last one being based on the characters observed during and after the grinding. The internal elements of the test (couches supplémentaires) are in this work named in accordance with Conil \& Lys (1964, p. 143). The following terms are used: choma, corner filling (remplissage de coins), thickening of the septum (épaississement de septum), knob (nodosité), spine (projection en forme d'épine) and hook (projection en forme de crochet). The latter three have by the method of 
grinding used proved often to be shaped as ridges going through the entire width of the chamber and having a knob-, spine- or hook-shaped crosssection. The orientation of thin-sections of coiled forms such as Endothyra is called horizontal for sections in the plane of the last coil and axial for sections at right angles to this.

The description given below follows an unpublished classification, which R. ConIL has kindly placed at the present author's disposal.

Familia Earlandidae Cummings 1955

Genus Earlandia Plummer 1930

Earlandia elegans (RAUSER-ČERNOUSSOVA \& REITLINGER 1937)

P1. I, figs. 1 and 2 (?); pl. XV, fig. 1.

1937. Hyperammina elegans RAuser-ČERnoussova \& ReItLinger, p. 256, fig. 191.

1964. Earlandia elegans (RAus.-Čern. \& ReItL.) - ConIL \& Lys, p. 53, pl. VII, figs. 98-99.

1969. Earlandia elegans (RAus.-ČERn. \& ReItl.) - Dvořák \& Conil, pl. 1, fig. 1.

Material: 4 specimens, of which 1 in thin-section.

Diagnosis: A species of the genus Earlandia which has a slightly conical, tubular chamber.

Dimensions: Greatest length measured $0.61 \mathrm{~mm}$, breadth of the tubular chamber $0.08-0.10 \mathrm{~mm}$, diameter of proloculum $0.11-0.12 \mathrm{~mm}$, thickness of wall $0.012-0.025 \mathrm{~mm}$.

Description: The test is tubular and has a globular proloculum whose diameter is larger than that of the tubular chamber. On the surface of the wall of the tubular chamber are seen some irregular constrictions. These do not correspond to any internal division into chambers. The tubular chamber is slightly conical. It has a fairly thick wall, while that of the proloculum is thin.

Remarks: The above described specimens are presumed to be identical with $E$. elegans. They differ, however, in that the tubular chamber is very slightly conica:. In all the other characters these specimens agrce with the holotype. They differ from E. vulgaris (RAUS. ČERN. \& ReITL. 1937) and E. vulgaris var. minor (RAUS.-CERN. \& REITL. 1948) in the smaller dimensions.

In 13 of the samples there are also found some fragments of a tubular test, often with aperture, but without initial part (see pl. I, fig. 2). Because of the dimensions of these fragments, their surface morphology and test structure 
it seems reasonable to assume that they may be fragments of this species. In pl. XXII they are marked "?".

Stratigra hical distribution:

Belgium: Tournaisian and Visean.

U.S.S.R.: Tournaisian, Visean and lowermost Namurian.

\section{Genus Lugtonia Cummings 1955}

\section{Lugtonia ? sp.}

Pl. I, fig. 3 .

Material: 1 specimen in thin-section.

Diagnosis: Uniserial, with indistinct sutures, well-developed septa.

Dimensions: Length $0.32 \mathrm{~mm}$, greatest breadth $0.15 \mathrm{~mm}$.

Remarks: On the outer surface of the test the division into chambers is indistinctly marked. The aperture and the septal foramen are surrounded by a small rim. This specimen apparently cannot be identified with any known species.

(Fam. indet.)

Gen. indet.

Indet. gen. sp. (F-75)

Pl. III, fig. 8.

Material: 2 specimens in thin-section.

Diagnosis: Uniserial, slightly curved, with reduced septa and cribrate aperture.

8 chambers.

Dimensions: Length $1.14 \mathrm{~mm}$, greatest breadth $0.34 \mathrm{~mm}$, diameter of proloculum $0.16 \mathrm{~mm}$.

Description: The test is large, uniserial and has its chambers placed along a curved line. The chambers are slightly inflated and are separated by clearly visible sutures. The aperture is terminal and cribrate.

The proloculum is globular and has an outer diameter of $0.16 \mathrm{~mm}$. The greatest breadth of the test is $0.34 \mathrm{~mm}$, and the length is $1.14 \mathrm{~mm}$. It consists of 8 chambers which increase moderately in size. The septa are greatly reduced. Between the last two chambers the septum is only partly reduced, as it is perforated by only a few, but large holes. The wall is thick and dark; it consists of carbonate with a granular microstructure; with a few inclusions of larger grains. 
Remarks: By its uniserial form, its reduced septa and its cribrate aperture this form differs from every known genus and species.

Distributed in a large number of samples fragments are found which correspond to the youngest part of this form. They are in this work referred to the genus Lituotubella, but some of these are perhaps fragments of the above-described form.

\title{
Familia Palaeotextulariidae Galloway 1933 \\ Genus Palaeotextularia Schubert 1921 \\ Palaeotextularia sp. \\ Pl. I. fig. 4.
}

Material: 1 specimen in thin-section.

Remarks: This specimen is clearly biserial. The outer surface is even, and the sutures are not cleariy visible. The wall is thick, and at a few places a faint indication of the presence of two layers may be seen. The specimen cannot be determined to species directly.

\section{Familia Tetrataxidae Galloway 1933 \\ Genus Tetrataxis EHRENBERg 1854}

Tetrataxis cf. pressulus MalaKhova 1956

\author{
P1. I, fig. 5.
}

Material: 4 specimens, of which 2 in thin-section.

Remarks: The four specimens are small and are rather poorly preserved. Their apical angle varies between $100^{\circ}$ and $120^{\circ}$. The greatest diameter is $0.52 \mathrm{~mm}$ and the corresponding height is $0.19 \mathrm{~mm}$. The ratio height/diameter is 0.37. The specimen with these dimensions (shown in pl. I, fig. 5), which is the largest and most complete of the four, has four whorls. The flanks of the test are slightly convex. These specimens differ from $T$. pressulus MalaKhova 1956 (p. 44) in the small size and the slightly convex flanks. Because of the height/diameter ratio and the number of whorls relative to the diameter they are here considered to be possible juvenile specimens of this species.

Tetrataxis cf. pusillus CONIL \& Lys 1964

Pl. I, figs. 6-7; pl. XV, figs. 2-3.

Material: 5 specimens, of which 3 in thin-section.

Diagnosis: A species of the genus Tetrataxis, with convex flanks and rounded margin. 
3-4 whorls; 4-5 chambers in the last whorl.

Dimensions: Diameter $0.31-0.42 \mathrm{~mm}$, height $0.15-0.25 \mathrm{~mm}$, height/ diameter $0.48-0.60$, apical angle about $90^{\circ}$.

Description: The test is trochospiral with a strongly convex spiral side and a concave umbilical side. The flanks of the spiral side are clearly convex. Thus it is not possible to give an exact measure of the apical angle. The margin is rourded and lobulate. The sutures are thin and slightly depressed but do not show clearly. They are pronouncedly obliquely placed relative to the spiral suture. The aperture is fissure-shaped, high and short, interiomarginal. It appears to continue as a narrow slit all the way in to the umbilicus.

The test has 3-4 whorls, which increase rapidly in size. The last whorl has 4-5 chambers. The thin-sections show the umbilical part of the aperture. The wall is fairly thin and consists of carbonate with a uniformly granular microstructure.

Remarks: This form differs from T. digna Grozdilova \& LeBEDEva 1954 in its height/diameter ratio being a little smaller. Chamberlets are not observed in the form studied. T. pusillus ConIL \& Lys 1964 (p. 95) is a little smaller than these specimens, and furthermore there are small divergenses in the size of the apical angle and in the height/diameter ratio. However, there seems to be no doubt that the form studied is very closely related to the latter species.

\section{Tetrataxis sp. 1}

P1. I. fig. 8 .

Material: 1 specimen in thin-section.

Diagnosis: A species of the genus Tetrataxis, with slightly convex flanks and fairly sharp margin.

3 (or perhaps 4) whorls.

Dimensions: Diameter $0.33 \mathrm{~mm}$, height $0.10 \mathrm{~mm}$ (?), apical angle about $120^{\circ}$.

Remarks: This specimen, which is characterized by a relatively large apical angle and an open umbilicus, shows some affinity to $T$. pressulus. A closer determination does not seem possible.

\section{Tetrataxis sp. 2}

Pl. I, fig. 9.

Material: 5 specimens, of which 2 in thin-section.

Diagnosis: A species of the genus Tetrataxis, with a very low spire and a sharp margin. 
2 (or perhaps 3 ) whorls; $4-5$ chambers in the last whorl.

Dimensions: Diameter $0.27-0.30 \mathrm{~mm}$, height $0.07-0.09 \mathrm{~mm}$, height/ diameter $0.26-0.33$, apical angle $140^{\circ}-160^{\circ}$.

Description: The test is small, trochospiral. The spiral side is slightly convex and the umbilical side slightly concave, so that the test in axial section is thin and crescent-shaped. The flanks of the spiral side are convex with a marginal concavity. Consequently, the apical angle is not a welldefined measure. The margin is sharp and slightly lobulate. The sutures are obliquely placed, but not clearly visible. The chambers are not inflated, but disc-shaped and overlap one another like roof-tiles. The aperture seems to be fissure-shaped and is short and high, and interiomarginal.

The test has 2, maybe 3 whorls, which increase only slowly in height but rapidly in breadth. The last whorl has $4-5$ chambers. The wall is thin. It consists of carbonate and has a uniformly granular microstructure.

Remarks: This form, which is characterized by a flattened shape and very sharp margin, seems to be identical with no known species. The flattened appearance is supposed to be primary.

This form occurs in the sample which also contains the above-described T. cf. pusillus.

Familia Tournayellidae DAIN 1953

Genus Brunsiina LIPINA 1953

Brunsiina pseudopulchra (LIPINA 1955)

Pl. I, figs. 10-13; pl. II, figs. 1-3; pl. XV, fig. 4.

1955. Glomospirella pseudopulchra LiPINA, p. 31, pl. II, figs. 25 \& 31.

1964. Glomospirella pseudopulchra LIPINA - ConIL \& LYs, p. 65, pl. VIII, figs. $137-144$.

Material: 19 specimens, of which 10 in thin-section.

Diagnosis: Disc-shaped, with a central thickening which is made up of the streptospirally coiled part.

6-9 whorls, of which $1 \frac{1 / 2}{2}-5$ are planispirally coiled.

Dimensions: Diameter $0.28-0.58 \mathrm{~mm}$, breadth of last whorl $0.08-0.14$ $\mathrm{mm}$, breadth/diameter $0.18-0.29$.

Description: The test is medium-sized, disc-shaped, has planeparallel sides and is circular or rarely oval in horizontal section. It is pronouncedly evolute. The umbilicus is broad and only slightly depressed and has a central rise. The margin is broadly rounded. The spiral suture is depressed but does not show really markedly. On the outer whorl is seen faint, irregular, 
transversal constrictions which correspond to sutures. The aperture is large, simple and terminal.

In the oldest part of the test the whorls are pronouncedly streptospirally coiled. The younger part of the test is planispiral. The streptospiral part is subglobular and has a diameter which usually is larger than the breadth of the following whorl, which causes the occurrence of the central hump in the umbilicus. It is difficult to determine the number of whorls in this part of the test, but it seems to be maximally $5 \frac{1}{2}$. There is an even transition between the streptospiral and the planispiral part, as the axis of coiling in the first couple of whorls in the latter part is still swinging. The planispiral part has $1 \frac{1}{2}-5$ whorls. The height of the whorls increases evenly, while the breadth increases only slowly. The overlap from one whorl to the next is very small in the planispiral part. Only a part of the last whorl is divided up by pseudosepta, which correspond to the outer constrictions. The wall consists of carbonate and has a granular microstructure.

Remarks: Because of the structure of the wall and the presence of pseudosepta this species must be placed in the genus Brunsiina.

All the specimens studied may on the basis of the outer characters of the test be referred to the same species. The small specimens (p. II, figs. 1-2) are thus assumed to be juvenile individuals. Only a few individuals (pl. I, figs. $11 \& 13$ ) show a decidedly oval horizontal outline.

\section{Stratigraphical distribution:}

Belgium: Visean.

U.S.S.R.: Upper Tournaisian to Upper Visean.

\section{Brunsiina spirillinoides (GrozdILOVA \& GLEBOvSKAIA 1948) \\ Pl. II, figs. 4-6; pl. XV, fig. 5.}

1948. Glomospira spirillinoides Grozdilova \& GlebovsKaia, p. 147, pl. I, figs. 2-4.

1963. Glomospirella spirillinoides (Grozd. \& Gleb.) - Conil, pl. I, fig. 12. 1964. Glomospirella spirillinoides (GRozD. \& GleB.) - ConIL \& Lys, p. 65, pl. VIII, figs. 145-149.

1969. Brunsia spirillinoides (Grozd. \& Gleb.) - DvořÁK \& Conil, pl. I, fig. 6 .

Material: 4 specimens, of which 3 in thin-section.

Diagnosis: Disc-shaped, without a central hump.

7-8 whorls, 4-5 of these planispirally coiled.

Dimensions: Diameter $0.53-0.60 \mathrm{~mm}$, breadth of last whorl $0.10-0.14$ $\mathrm{mm}$, breadth/diameter $0.18-0.23$. 
Description: The test is irregularly disc-shaped, biconcave, and evolute. The umbilicus is broad, slightly depressed, and without a central hump. The horizontal outline is subcirculai. The margin is round to broadly rounded. The spiral suture shows fairly clearly, and is sligthly depressed. The last whorl is divided up by transversal, irregular, slight constrictions, which may correspond to sutures. The aperture is not observed.

The oldest part of the test has 3-4 whorls, which are closely streptospirally coiled. The diameter of this part of the test is smaller than or equal to the breadth of the following whorl. The youngest 4-5 whorls are planispirally coiled without overlap from one whorl to the preceding one. The transition between the two parts of the test is even, as the first couple of whorls in the planispiral plane depart a little from it. The height of coiling increases slightly, while the increase of the breadth is faster. At least a part of the last whorl is divided up by pseudosepta, which correspond to the outer constrictions. The wall consists of carbonate and has a granular microstructure.

Remarks: Because of the structure of the wall and the presence of pseudosepta (see also ConIL \& Lys, 1964, pl. VIII, fig. 146) this species must be referred to the genus Brunsiina.

One of the three thin-sections (pl. II, fig. 5) differs from the other two in having a brownish and more even surface of the test. Because of the build of the test they are all considered to belong to the same species.

The specimens examined differ from $B$. pseudopulchra in lacking a central hump in the umbilicus. They differ from B. uralica Lipina (cf. Conil \& Lys, 1968, pl. II, fig. 18) in the larger dimensions for equal numbers of whorls.

Stratigraphical distribution:

Belgium: Visean.

U.S.S.R.: Upper Tournaisian to Lower Visean.

Genus Conilites VDovenKo 1970

Conilites dinantii (CONIL \& LYs 1964)

Pl. VI, figs. 1-3.

1964. Ammobaculites (?) dinantii ConIL \& Lys, p. 67. pl. VIII, fig. 153.

1970. Conilites dinantii (ConIL \& Lys) - Vdovenko, p. 78, pl. III, figs. $3 \& 6$.

Material: 5 specimens, of which 3 in thin-section.

Diagnosis: Initial part nearly planispiral, uniserial part straight.

31/2-4 whorls; $8-9$ chambers in the last whorl.

Dimensions: Diameter 0.89-0.95 mm, maximal length $1.25 \mathrm{~mm}$. 
Description: The test is nearly planispiral and has a uniserial final part. The spirally coiled part is evolute and has an open and clearly depressed umbilicus. The margin is rounded and slightly lobulate to lobulate. The sutures show clearly; they are depressed and obliquely backward-pointing. The chambers are only slightly inflated. In the uniserial part both the chambers and the sutures are more clearly marked. The aperture is cribrate and terminal.

The spirally coiled part has $31 / 2-4$ whorls, which are coiled in one plane except for the first whorl, which makes a distinct angle with the plane of the following whorls. The last whorl has 8-9 chambers. The chambers are separated by pseudosepta; however, the last whorl has very rudimentary but strong septa. The height and breadth of the whorls increase rapidly. The septa of the uniserial part are also rudimentary except for the youngest one, which is entire and is perforated by a few holes (cribrate). The wall is fairly thick; it consists of carbonate and has a granular microstructure; inclusions of larger grains occur.

Remarks: The specimens studied are considered to be identical with Ammobaculites (?) dinantii ConIL \& Lys 1964 in spite of the slightly smaller diameter of the planispiral part.

The three specimens shown in pl. VI, figs. 1-3 differ from one another in a few characteristics. The specimen shown in fig. 2 differs from the other two specimens in having a light, somewhat uneven surface of the test and in having more distinct sutures. In thin-section the oldest whorls of the specimens shown in figs. 2 and 3 are very diffuse, while these whorls in the specimen of fig. 1 are very clearly marked and show the deviation from the plane of symmetry. These differences are supposed to be due to in part the normal variation within the species and in part the different condition of preservation.

Stratigraphical distribution:

Belgium: Tournaisian $3 \mathrm{c}$ and Visean $1 \mathrm{~b}$ (?).

U.S.S.R.: Lower Visean.

Genus Lituotubella RAuSER-ČERnOUSSOva 1948

Lituotubella glomospiroides minima n. subsp.

P1. IV, figs. 3-7.

Derivation of the name: From the small size of this subspecies.

Holotype: D.G.U. catalogue No. 1970-OM-43; pl. IV, fig. 7.

Type locality: The boring Ørslev No. 1, D.G.U. file No. 238.502. 
Type bed: Claystone, very calcareous, dark grey, with zones of limestone. Depth $7700^{\prime}$.

Material: 28 specimens, of which 10 in thin-section.

Diagnosis: The initial part is streptospirally coiled. The uniserial part is long and slightly curved.

3-4 whorls; 5-6 chambers in the last whorl. As many as 8 (?) chambers in the uniserial part.

Dimensions: Maximal length $1.77 \mathrm{~mm}$, diameter $0.48-0.55 \mathrm{~mm}$.

Description: The test is elongated and has a coiled initial part and a uniserial final part. The initial part is evolute and has a slight hump in the umbilicus. The margin is rounded and lobulate. The sutures are slightly depressed but not sharp. Also in the uniserial part they are irregular and not clearly visible. The test is characterized by the relatively even transition between the two parts of the test. The uniserial part is slightly curved. The aperture is cribrate and terminal.

The initial part has 3-4 whorls, which are streptospirally coiled. The last two whorls appear to be at right angles to each other. The last whorl has 5-6 chambers. The septa are strongly reduced. In a part of the last whorl and in the uniserial part there often are stronger but still very short septa. The last septum (in the uniserial part) is entire, but perforated by a few, large holes. In both parts of the test, the size of the chambers increases only slowly. The wall is fairly thick. It consists of carbonate and has a granular microstructure; inclusions of larger grains are common.

Remarks: This form differs from L. glomospiroides RAUSER-ČERNOUSSOVA 1948, L. glomospiroides var. magna RAUSER-ČERNOUSSOVA 1948 and L. glomospiroides var. scalaeformis CONIL \& LYS 1964 in being smaller and in having a smaller uniserial part with a relatively large number of chambers. Except for the difference in size, it shows close similarity to L. glomospiroides var. scalaeformis. Both this form and the one studied have a pronouncedly streptospirally coiled initial part and fairly marked septa in the uniserial part. The latter character suggests a connection to the genus Pseudolituotubella. The material studied includes a few specimens which are difficult to distinguish from those forms which in this work are described under the latter genus.

As a result of the method of disintegration of the rocks here used, entire specimens are rare in this material. The specimens studied consist normally of only the streptospiral part. Thus it may be difficult to determine them. Here the determination is made by means of the outer characters and their comparison with a few thin-sections. Fragments from the uniserial part are not determined but are marked "?" in plate XXII. However, these might also be fragments of the above-described form Indet. gen. sp. (F-75). 
Genus Palaeospiroplectammira LIPINA 1965

Palaeospiroplectammina diversa (CHERNYSHEVA 1948)

Pl. III, figs. 4-7; pl. XVI, figs. 1-3. Text-fig. 4.

1948. Palaeotextularia diversa Chernysheva, p. 248, pl. 18, figs. 7-8.

1965. Spiroplectammina brevicula ConIL \& Lys, p. 27, pl. I, figs. 5-8.

1968. Palaeospiroplectammina diversa (CHERnysheva) - CONIL \& Lys, p. 506, pl. III, fig. 29.

Material: 31 specimens, of which 3 in thin-section and 10 as fluorite preparations.

Diagnosis: A very small coiled initial part and a very dominant biseria] part, which increases rapidly in breadth.

5 chambers in the initial part; 5-10 chambers in the biserial part.

Dimensions: Length $0.49-1.05 \mathrm{~mm}$, breadth $0.43-0.80 \mathrm{~mm}$.

Description: The test is large, biserial, and has a coiled initial part. The initial part may usually be observed on the surface of the test, as one or two of the chambers of this part appear not to fit into the normal biserial arrangement. The outer appearance corresponds in its other features with Palaeotextularia. The initial part of the test is often slightly twisted relative to the rest of the test. The breadth of the biserial part increases rapidly with the length. The margin is broadly rounded and sligthly lobulate. The sutures are sligthly depressed and show clearly but not sharply. The chambers are slightly inflated. In the initial part the sutures and the chambers are not clearly visible. The aperture is fissure-shaped and interiomarginal.

The coiled part has 5 chambers, which are arranged in the form of a tetrahedron with the proloculum in the center. Thus there is only one whorl, which may be considered to be streptospirally coiled. In the biserial part, which dominates the test, the size of the chambers increases rapidly. The septa are, like the wall, thick, curved, and terminally thickened. Their overlap is marked. The wall consists of carbonate and has a granular microstructure with inclusions of larger grains.

Remarks: In the chambers may often be seen a thin, brownish organic film. Due to the presence of this film it is possible in the fluorite preparations (see p. 17) to see not only the individual chambers but also the connections between these. In this way and by careful observation during the grinding it has been possible to prove that the proloculum and the four following chambers are tetrahedrally grouped (see text-fig. 4). This initial part may be considered as being streptospirally coiled with one whorl, so that this species may be referred to the genus Palaeospiroplectammina.

The specimens examined vary from the long, narrow form of CoNIL \& Lys (1968) through the holotype to P. brevicula. Since they in all characters 


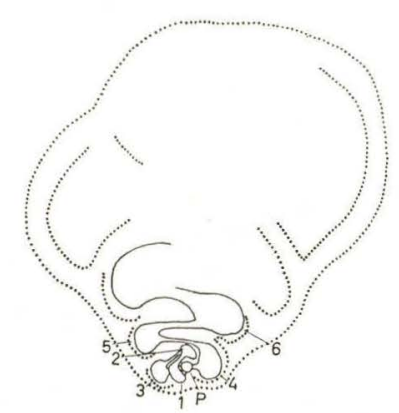

Text-fig. 4: Palaeospiroplectammina diversa (CHERNYSHEVA 1948) from 8230'-8240'. Diagram of a fluorite preparation. The outer and inner surfaces of the wall are shown by dotted lines; the organic film is shown by a full-drawn line. $\mathrm{P}$ is proloculum; 1-6 are the six following chambers, in sequence from older to younger. About 50x.

except the size of the apical angle seem to be identical they are here presumed to belong to the same species. R. ConIL has found a similar scattering in the Belgian material (personal communication).

Stratigraphical distribution:

Belgium: Tournaisian $3 \mathrm{c}$, Visean 1a \& $1 \mathrm{~b}$.

U.S.S.R.: Upper Tournaisian and Lower Visean.

"Palaeospiroplectammina" mellina (MaLaKhova 1965)
Pl. II, figs. 7-11; pl. XV, figs. 6-9. Text-fig. 5.

1965. Spiroplectammina mellina Malakhova, p. 121, pl. XV, fig. 6.

1968. Palaeospiroplectammina mellina (MalaKhova) - CONIL \& Lys, p. 506, pl. III, figs. 36-38.

Material: About 450 specimens, of which 17 in thin-section and 39 as fluorite preparations.

Diagnosis: The initial part is trochospiral and has a rounded outline; the biserial part is dominating.

As many as 16 chambers in the biserial part; 6 in the coiled part.

The septa are curved and show a slight overlap.

Dimensions: Length $0.18-0.68 \mathrm{~mm}$, breadth $0.15-0.30 \mathrm{~mm}$, breadth/ length $0.43-0.83$.

Description: The test is fairly small and is biserial with coiled initial part. Its dimensions are somewhat varying, in that the length varies from $0.18 \mathrm{~mm}$ to $0.68 \mathrm{~mm}$ (most often $0.30-0.50 \mathrm{~mm}$ ) and the breadth from $0.15 \mathrm{~mm}$ to $0.30 \mathrm{~mm}$ (most often $0.19-0.25 \mathrm{~mm}$ ). The test is conical and has an initial 
part with a rounded outline. The division into chambers of the initial part does not show clearly on the surface of the test. In the biserial part the sutures show clearly and are depressed but not sharp. The chambers are slightly inflated. The surface of the test is rough. The aperture is fissureshaped, low and inicriomarginal.

The initial part has a proloculum and 5 chambers, which are trochospirally coiled, so that it must be designated triserial. The biserial part has 2-16 chambers. The cross section of the triserial part is subcircular. The breadth of the test increases somewhat irregularly; in a few cases it does not seem to increase at the last chamber. The height of the chambers increases moderately. In the triserial part the shape and length of the septa cannot be observed. In the biserial part they are fairly long, curved, and terminally thickened, and have medially a slight overlap. The wall consists of carbonate and has a granular microstructure with inclusions of a few larger grains. Inside the chambers a thin, brown organic film is observed.

Remarks: The thin-sections examined seem to be identical with the figures in ConIL \& Lys (1968). The thin-sections give a certain indication that this form cannot have a streptospiral initial part. The thin-sections show lowermost a chamber (proloculum), above this two chambers of a whorl and above these two a small part of a chamber which is located on the median line of the test. This pattern is difficult to interpret as a streptospiral coiling. This conclusion is confirmed by the fluorite preparations (see p. 17), which show that actually the proloculum is followed by a trochospiral part with 5 chambers, which are presumably triserially arranged (see text-fig. 5).

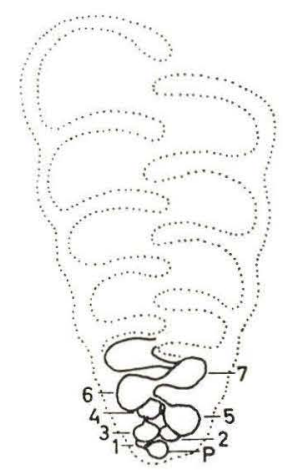

A

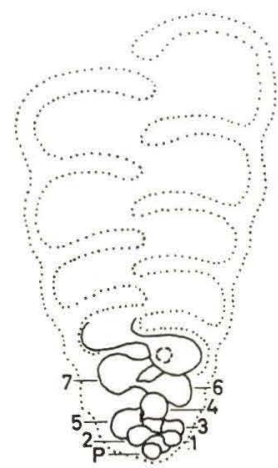

B

Text-fig. 5: "Palaeospiroplectammina" mellina (Malakhova 1965) from core No. 2, $7728^{\prime}$. Diagram of a fluorite preparation. The test is shown in two views, A and B. The outer and inner surfaces of the wall are shown by dotted lines; the organic film is shown by a full-drawn line. $\mathrm{P}$ is proloculum; $1-7$ are the seven following chambers, in sequence from older to younger. About 100x. 
This form may show an outer similarity to Palaeotextularia ScHUBERT 1921 , but differs from it in having a granular microstructure of the wall and also differs in not having a biserial initial part. Gaudryina D'ORBIGNY 1839 has an agglutinating wall. Palaeospiroplectammina LIPINA 1965 has a streptospiral initial part but is in all other respects similar to the form described. The arrangement of the chambers in Paleogaudryina SAID \& BARAKAT 1958 corresponds with the above-described one, but the wall is agglutinating and the aperture is high and narrow. The "Palaeospiroplectammina" mellina here described thus shows some similarity with Paleogaudryina, but nevertheless it differs so much from this and other known genera that it must be supposed to represent a new genus.

It is difficult to determine the structure of the initial part by thin-sections only. Thus it might possibly be that among the known species of the genera Palaeotextularia and Palaeospiroplectammina there may be a few that have a trochospiral (triserial) initial part. Cummings (1956, p. 217) writes as follows about Palaeotextularia: "..... in some microspheric forms and very rarely in some megalospheric forms, the earliest chambers are coiled in a "circular" manner; ......". A renewed study of among others the Russian types would presumably make it possible to determine whether the above-described characters are unique for the specimens examined or whether they, as presumed, are characters of a fairly common form, which then ought to be referred to a new genus.

Stratigraphical distribution:

Belgium: Visean 1a, 1b \& $2 \mathrm{~b}$.

U.S.S.R.: Lower Visean.

"Palaeospiroplectammina"sp.

Pl. II, fig. 12.

Material: 1 specimen in thin-section.

Remarks: This specimen, which is ground in a plane at right angles to the biserial one, cannot be determined with certainty. The coiling of the initial part is not finally determined. It is perhaps streptospiral, in which case the specimen would belong to the genus Palaeospiroplectammina.

\section{Palaeospiroplectammina venusta (VDOVENKo 1954)}

Pl. II, figs. 13-15; pl. XV, figs. 12-13.

1954. Spiroplectammina venusta VDovenko, pl. 3, figs. 6-7.

1964. Siroplectammina tarda CONIL \& Lys, p. 84, pl. XI, figs. 211-212. 
1965. Spiroplectammina tarda ConIL \& LYS - ConIL \& LYS, p. 29, pl. I, fig. 10.

1968. Palaeospiroplectammina venusta (VDovenko) - ConiL \& Lys, p. 506, pl. III, fig. 30.

1969. Palaeospiroplectammina venusta (VDOvenKo) - Conil et al., p. 58, pl. II, fig. 14.

Material: 9 specimens, of which 6 in thin-section.

Diagnosis: A species of the genus Palaeospiroplectammina in which the breadth of the biserial part is smaller than the diameter of the coiled part.

As many as 9 chambers in the biserial part; 5-6 chambers in the last whorl.

Dimensions: Length $0.33-0.58 \mathrm{~mm}$, breadth $0.17-0.24 \mathrm{~mm}$, diameter $0.18-0.30 \mathrm{~mm}$.

Description: The test is medium-sized, biserial, and has a coiled initial part. The two parts of the test are twisted a little relative to each other, so that they do not lie in the same plane. The breadth of the biserial part is smaller than the diameter of the coiled part. The latter is evolute and has a slightly depressed umbilicis. Its margin is rounded and lobulate. The sutures are thin, clearly visible, radial, and depressed. The chambers of the last whorl are subglobular. The biserial part is slightly twisted and has a uniform breadth. The margin of the biserial part is rounded and slightly lobulate. The sutures are broader and less clearly visible than in the coiled part. The surface of the test is even. The aperture is fissure-shaped and interiomarginal.

The coiled part has 2-3 whorls, which are typically streptospirally coiled. The last whorl, which appears to lie in one plane, has 5-6 chambers. These increase only slowly in size. The septa are fairly well-developed and terminally thickened. The chambers of the biserial part increase moderately in height. Its septa are curved, long, show a pronounced overlap, and are terminally thickened. The wall consists of carbonate and has a granular microstructure.

Remarks: A few of the specimens (see pl. II, figs. 13-14) have within the chambers a thin, brown organic film. In one of the thin-sections (pl. II, fig. 14) the wall seems to consist of two layers, an outer, dark one and an inner, light one. No difference in structure is found between the two layers. The difference in colour between the two layers might possibly be explained by the tendency to include foreign material in the wall, which according to the literature seems to be characteristic of this genus.

This species differs from Spiroplectammina gloriosa Grozdilova \& LeBEDEVA 1954 in having both a smaller diameter and a smaller length. Also the wall does not seem to be as strongly developed as in S. gloriosa. The relation 
between $P$. venusta and $P$. tarda is discussed in ConIL \& Lys $(1965$, p. 29) and in Conil et al. (1969, p. 58).

Stratigraphical distribution:

Eelgium: Tournaisian 3 c (?), Visean 1 a, 1 b \& 2 a.

U.S.S.R.: Visean $\mathrm{C}_{1 \mathrm{a}}, \mathrm{C}_{1 \mathrm{~b}}$, \& $\mathrm{C}_{1 \mathrm{c}}$.

\section{Palaeospiroplectammina aff. tchernyshinensis (LIPINA 1948) ${ }^{1}$}

Pl. III, figs. 1-2; pl. XV, figs. 10-11.

Material: 5 specimens, of which 4 in thin-section.

Diagnosis: A species of the genus Palaeospiroplectammina in which the breadth of the biserial part is greater than the diameter of the streptospiral part.

As many as 9 chambers in the biserial part; 4-5 chambers in the last whorl.

Dimensions: Length $0.34-0.57 \mathrm{~mm}$, breadth $0.17-0.23 \mathrm{~mm}$, diameter $0.14-0.17 \mathrm{~mm}$.

Description: The test is medium-sized, biserial, and has a coiled initial part. The test twists only slightly, so that its two parts lie nearly in the same plane. The breadth of the biserial part is greater than the diameter of the coiled part and increases moderately with the length of the test. The spirally coiled part of the test is evolute and has a narrow umbilicus which is not depressed. Its margin is rounded and lobulate. The sutures are depressed, radial, and do not show very sharply. The chambers are slightly inflated, while those of the biserial part are inflated and more strongly developed. The sutures of the biserial part are also depressed, but they do not show clearly. The surface of the test is even. The aperture is interiomarginal. It appears to be fissure-shaped and open.

The spirally coiled part has $1 \frac{1}{2}-2$ whorls, which are strongly streptospirally coiled. The last whorl has $4-5$, usually 4 , chambers. These increase only slowly in size. The septa are curved, point forward, and are terminally thickened. They are long, their length being greater than halfpart of the height of the chambers. In the biserial part the size of the chambers increases moderately. In this part of the test the septa are long, curved, and have a distinct terminal thickening. They show marked overlap. The wall consists of carbonate with a uniformly granular microstructure.

1) Palaeospiroplectammina aff. tchernyshinensis is probably identical with $P$. sinensis LIPINA 1970 (p. 19, pl. I, figs. 1-2). The present paper was written before the publication of LIPINA 1970; furthermore, it has been difficult for the author to properly understand the Russian text. 
Remarks: Especially within the oldest chambers is found a thin, brown organic film.

On the basis of the arrangement of the chambers, both in the biserial and in the coiled part, this form seems to be identical with Spiroplectammina tchernyshinensis LIPINA 1948 (pp. 256-257). It differs mainly in having a smaller diameter of the coiled part at the same time as having a larger number of chambers in the last whorl. Although the differences in the form studied are very small it cannot with certainty be referred to P. tchernyshinensis.

\section{Palaeospiroplectammina sp.}

Pl. III, fig. 3 .

Material: 1 specimen in thin-section.

Diagnosis: A species of the genus Palaeospiroplectammina in which the breadth of the biserial part is a little smaller than the diameter of the coiled part.

8 chambers in the biserial part; $5 \frac{1}{2} 2$ chambers in the last whorl.

Dimensions: Length $0.43 \mathrm{~mm}$, breadth $0.19 \mathrm{~mm}$, diameter $0.15 \mathrm{~mm}$.

Remarks: It has not been possible to refer this specimen to any known species. It differs from $P$. venusta in having a rough surface of the test and in having a smaller initial part.

\section{Genus Pseudolituotubella VDOvenKo 1967 \\ Pseudolituoîubella aff. tenuissima (VDOVENKo 1954) \\ Pl. V, figs. $1-3$.}

Material: 7 specimens, of which 4 in thin-section.

Diagnosis: Streptospiral initial part and a short and thick uniserial part.

$2 \frac{1}{2}-3$ whorls; 5-6 chambers in the last whorl; at least 2 chambers in the uniserial part.

Dimensions: Diameter 0.51-0.62 mm, length 0.66-0.86 mm.

Description: The coiled part of the test is slightly asymmetric. The margin is rounded and lobulate. The sutures show clearly and are depressed. In both parts of the test the chambers are inflated. The aperture is cribrate and terminal.

The initial part is streptospirally coiled and has $2 \frac{1}{2}-3$ whorls. The last whorl has 5-6 chambers. The height of the whorls increases moderately. The first whorls are divided up by pseudosepta, while the last whorl has reduced septa. These latter are fairly short and thick. The last septum in the uniserial 
part is entire and has a cribrate foramen. The wall is fairly thick. It consists of carbonate and has a granular microstructure with inclusions of a few larger grains.

Remarks: These specimens differ from $P$. tenuissima in having a somewhat smaller diameter and length. Also, the coiled part appears to be less pronouncedly streptospirally coiled. In $P$. tenuissima the breadth of the uniserial part is relatively large. This is the case for only one specimen ( $\mathrm{pl}$. V, fig. 1) out of all the ones examined; this specimen is also in its other characteristics very similar to $P$. tenuissima.

\section{Pseudolituotubella sp. 1}

Pl. V, fig. 7.

Material: 1 specimen in thin-section.

Diagnosis: The streptospiral part is fairly small. The uniserial part is short and fairly thin.

$2 \frac{1}{2}$ whorls; 6 chambers in the last whorl; 2 chambers in the uniserial part.

Dimensions: Diameter $0.50 \mathrm{~mm}$, length $0.74 \mathrm{~mm}$.

Remarks: This specimen differs from $P$. aff. tenuissima in having a more slender and elongated shape. The chambers are less inflated, especially in the uniserial part. The streptospiral coiling is more simple.

\section{Pseudolituotubella sp. 2}

Pl. IV, figs. 1-2.

Material: 14 specimens, of which 4 in thin-section.

Diagnosis: The initial part is moderately streptospirally coiled; the uniserial part is presumed to be short.

$2 \frac{1}{2}-3 \frac{1}{2}$ whorls; 5 chambers in the last whorl; 2 or more chambers in the uniserial part.

Dimensions: Diameter 0.44-0.58 mm, greatest length measured $0.76 \mathrm{~mm}$.

Description: A coiled initial part followed by a uniserial part. The coiled part is evolute and has a small and only slightly depressed umbilicus. The margin is rounded and slightly lobulate. The sutures are slightly depressed and do not show clearly. The chambers are unevenly inflated. In the uniserial part the chambers and the sutures are more clearly marked. Furthermore, the outer surface of the test is very characteristic in showing a sudden transition from the coiled part to the uniserial part. The aperture is cribrate.

The initial part has $21 / 2-31 / 2$ whorls, which are moderately streptospirally. 
coiled, so that the total rotation of the axis of coiling from the first to the last whorl is about $90^{\circ}$. The last whorl has 5 fairly long chambers. The height of the whorls increases slowly to moderately. The streptospiral part is divided up by pseudosepta; however, rudimentary septa are found in a part of the last whorl. In the uniserial part the septa are also rudimentary, but are stronger; the last septum is entire and has a cribrate foramen. The wall is fairly thick and consists of carbonate and has a granular microstructure; inclusions of larger grains are common.

Remarks: This form is probably a new species, which is very closely related to $P$. tenuissima. It differs from $P$. tenuissima in being smaller and in having more whorls. The coiling of the streptospiral part is more even than in $P$. tenuissima.

All the specimens with the exception of one (pl. IV, fig. 1) are fragmentary. Consequently the final part of the test is not known with any certainty.

\section{Pseudolituotubella sp. 3}

Pl. V, figs. 4-5 and 6 (?).

Material: 4 specimens, of which 3 in thin-section.

Diagnosis: The initial part is streptospiral and has rudimentary septa in the last whorl. The septa in the uniserial part are reduced but strong.

4-5 (?) whorls; 5-61/2 chambers in the last whorl; more than 5 chambers in the uniserial part.

Dimensions: Diameter 0.42-0.60 mm, length more than $1.44 \mathrm{~mm}$.

Remarks: The outer surface of the test corresponds on the whole with that of Lituotubella glomospiroides minima. However, Pseudolituotubella sp. 3 has a more continuous and even transition from the initial part to the uniserial part. This form differs from the known species also in having a small initial part whose whorls are rapidly increasing in size and pronouncedly streptospirally coiled. The septa of the uniserial part are short but very strong. It is reasonable to assume that Pseudolituotubella sp. 3 is a new species. The material present, four specimens, is both small and fragmentary. The last chambers, and thus also the aperture, are unknown. A fragment of a uniserial part (see pl. V, fig. 6) shows a very characteristic cribrate aperture with a very thick wall between the individual openings. Although the wall and the septa in this fragment show close resemblance to Pseudolituotubella sp. 3 there is no certainty of identity with this form. Also, Pseudolituotubella sp. 3 is not found in the sample containing the above-mentioned fragment. 
Genus Septabrunsiina Lipina 1955

Septabrunsiina spissusvoluta $n$. sp.

Pl. VI, figs. 4-7; pl. XVI, fig. 4.

Derivation of the name: Spissus means compressed and volutus means whorl.

Holotype: D.G.U. catalogue No. 1970-OM-57; pl. VI, fig. 7.

Type locality: The boring Ørslev No. 1, D.G.U. file No. 238.502.

Type bed: Limestone, grey to dark grey, with calcareous claystone. Depth $8280^{\prime}-8290^{\prime}$.

Material: 8 specimens, of which 7 in thin-section.

Diagnosis: The test is disc-shaped and evolute. The streptospiral part is broader than the planispiral part.

5-7 whorls, of which 2-4 are planispirally coiled; $9-11$ chambers in the last whorl.

Dimensions: Diameter $0.27-0.48 \mathrm{~mm}$, breadth of the streptospiral part $0.11-0.13 \mathrm{~mm}$, breadth of the last whorl $0.10-0.12 \mathrm{~mm}$.

Description: The test is disc-shaped and evolute. The umbilicus is broad and is slightly depressed with a central hump, which on the surface of the test marks the extent of the streptospiral part. The margin is rounded and lobulate. The sutures show clearly and are fairly broad; they are darker than the surrounding test material. They are depressed and radial to obliquely backwards bent. The chambers are slightly inflated. The surface of the test is fairly even. The aperture appears large, fissure-shaped and interiomarginal.

The first 3-4 whorls are pronouncedly streptospirally coiled. The septa are strongly reduced. This part of the test is subglobular and has a greater breadth than the following whorls. The planispiral part has 2-4 whorls. The transition between the two types of coiling is fairly even. The last whorl has 9-11 chambers. The height and breadth of the whorls increase fairly slowly. The chambers are low and elongated. They are separated by reduced septa which point obliquely forwards. The older septa converge more toward the wall than the younger ones do. The septa are a little thicker than the wall. In the planispiral part the individual whorls overlap only slightly. The wall consists of carbonate and has a granular microstructure.

Remarks: S. spissusvoluta differs from the genotype, S. krainica (LIPINA 1948), in having reduced septa in the older whorls and in having a large number of chambers in the last whorl. Endothyra ? minuta LiPINA 1948 seems in a few of its features to be closely related to the above-described 
species. E. ? minuta is, however, smaller and has less pronouncedly streptospirally coiled whorls in the initial part. It has no central hump in the umbilicus.

Genus Septatournayella Lipina 1955

Septatournayella pseudocamerata LEBEDEVA 1954

Pl. VII, fig. 1.

1954. Septatournayella pseudocamerata Lebedeva, p. 243, pl. I, fig. 12.

Material: 1 specimen in thin-section.

Diagnosis: The test is evolute and nearly planispiral.

5 (6?) whorls; $81 / 2$ chambers in the last whorl.

Dimensions: Diameter $0.96 \mathrm{~mm}$, breadth $0.46 \mathrm{~mm}$.

Remarks: This specimen is not exactly bilaterally symmetrical. Also in Lebedeva (1954, fig. 12) the whorls seem to deviate from the plane of symmetry. Also on the outside the specimen studied is asymmetrical. The margin is broadly rounded. The chambers are inflated and are separated by well-defined sutures.

In his description of the genus LIPINA (1955, p. 38) names this species Septatournayella pseudocamerata LiPINA 1955. Since LebedeVA's description is dated earlier than LIPINA's, and since "there is no evidence to suggest that Lipina was responsible for the 1954 description the species must be considered as new in 1954, authored by Lebedeva" (Ellis \& Messina, 1940 ff.).

Stratigraphical distribution:

U.S.S.R.: Upper Tournaisian and Visean.

Familia Endothyridae BRADY 1884

Subfamilia Endothyrinae BRADY 1884

Genus Endothyra Phillips 1846

Endothyra cf. apposita GANELINA 1956

Pl. VII, figs. 2-3.

Material: 2 specimens in thin-section.

Diagnosis: Pronouncedly streptospirally coiled.

3-4 whorls; 71/2 chambers in the last whorl.

Internal elements: Lcw ridges with rounded cross-section. In the last chamber the ridge is high and well-developed and has a hook-shaped crosssection.

Dimensions: Diameter $0.56 \mathrm{~mm}$ and $0.79 \mathrm{~mm}$. 
Remarks: These two specimens are not selected on the basis of their external characters, but are separated by means of thin-sections from the groups Endothyra sp. 1 and Endothyra sp. 2, which are described below. The relationship to these two groups and to $E$. cf. bradyi is not well defined. Probably these four groups represent different elements of an evolution in which the degree of streptospiral coiling changes slightly and the internal elements (ridges) become higher and more well-developed.

In GANELINA (1956, p. 89) the internal elements are described as "weakly developed". However, the variation of this part of the test is large (cf. CoNIL \& LYs, 1968, p. 516). In the Belgian material specimens cccur which have fairly wel'-developed ridges in the last chambers (ibidem, pl. VI, fig. 67). On the basis of this the two specimens are set in relation to E. apposita.

Endothyra cf. bradyi MiKhaILov 1939

Pl. VII, figs. 4-8; pl. VIII, figs. 1-2: pl. XVI, figs. 5-8.

Material: More than 150 specimens, of which 14 in thin-section.

Diagnosis: Pronouncedly streptospirally coiled.

$3-3 \frac{1}{2}$ whorls; $61 / 2-8$ chambers in the last whorl.

Internal elements: Well-developed ridges; they have a pointed cross-section which points obliquely forward, and they increase clearly in height in the last chambers. Corner fillings and thickenings of the septa are common.

Dimensions: Diameter $0.42-0.87 \mathrm{~mm}$, breadth $0.27-0.40 \mathrm{~mm}$, breadth/ diameter 0.50-0.66.

Description: The test is asymmetric, being evolute on one side and evolute/involute on the other. The margin is rounded and lobulate. The umbilical area is depressed only on the involute side. The chambers are inflated and are separated by clearly visible, radial and depressed sutures. The surface of the test is dark and relatively even. The aperture is a short and fairly high fissure and is interiomarginal. The apertural face is placed obliquely across the margin of the preceding whorl, so that the major part of the last chamber clings to one side of the test.

The test has $3-3 \frac{1}{2}$ whorls, which are pronouncedly streptospirally coiled. The last whorl has $61 / 2-8$ chambers, usually 7 . The height and breadth of the whorls increase fairly rapidly. The septa are fairly long and are curved and forward-pointing. Their terminal edge appears to be turned forward, so that in cross-section they have an S-shaped appearance. The internal elements, the ridges, are well-developed but normally are not connected from one chamber to the next. The ridges show a triangular cross-section and incline forward. They increase in height in the last chambers and may in the last one often attain half the height of the chamber. Corner fillings and 
thickenings of the septa are observed in some of the thin-sections. The wall consists of carbonate and has a granular microstructure.

Remarks: This form seems to form a well defined group both by the outer and the inner characters. In the latter characters it shows affinity to Endothyra cf. apposita, Endothyra sp. 1, and Endothyra sp. 2. It differs from these three in having a clearly asymmetrical and slightly inflated shape.

The form studied differs from all known varieties of $E$. bradyi MikHaILOv 1939 (p. 51). It is both larger and has more well-developed ridges. The triangular cross-section of these and their great height in the last chamber distinguishes this form from the group E. bradyi. A few specimens (pl. VII, fig. 7) with relatively small and uniform ridges, however, show affinity to E. bradyi obsoleta RAUSER-ČERNOUSSOVA 1948. Some specimens with a fairly high and ascending ridge in the last chamber indicate a connection with $E$. delepinei (ConIL \& Lys 1964), which, however, is also a fairly small form with few and pronouncedly streptospirally coiled whorls. One specimen (pl. VIII, fig. 1) even shows affinity to E. volynica Bražnikova 1956. Also E. phrissa (ZELLER 1953) is a species which is characterized by forward-pointing ridges with clearly increasing height in the last chambers. In $E$. phrissa there seems often to be connection between the ridge from one chambar to the next.

$E$. cf. bradyi is without doubt one species, perhaps with some varieties, which forms elements in the trends of evolution between the above-mentioned species. Since it is found in a hitherto not known series of beds, and since the samples moreover are ditch samples, it is not possible to place it more exactly relative to known species. However, it should be pointed out that as far as its outer shape is concerned it is well defined and uniform, so that it must for the time being be considered as one species.

\section{Endothyra sp. 1}

Pl. VIII, figs. 3-6; pl. XVII, figs. 1-3.

Material: 32 (?) specimens, of which 7 in thin-section.

Diagnosis: Pronouncedly streptospiral in the first whorls; almost planispiral in the last whorl.

$3 \frac{1}{2}-4 \frac{1}{2}$ whorls; $71 / 2-9$ chambers in the last whorl.

Internal elements: Strong and low ridges with rounded cross-section; in the last chamber they are often hook-shaped. Corner fillings and thickenings of the septa occur.

Dimensions: Diameter $0.63-0.84 \mathrm{~mm}$, breadth $0.35-0.46 \mathrm{~mm}$, breadth/ diameter $0.53-0.55$.

Description: The test is large and has an almost bilaterally symmetrical outer shape. It is slightly evolute and has a clearly depressed umbilical area. 
The margin is rounded to broadly rounded and lobulate. The horizonial outline of the test is often oblong subtriangular. The sutures are clearly visible and only a little depressed; they are radial. The surface of the test is dark and even. The aperture is fissure-shaped and interiomarginal. It is slightly asymmetrical, the opening being widest over the margin and narrowing across one side of the preceding whorl.

The test has $3 \frac{1}{2}-4 \frac{1}{2}$ who-ls, which at first are pronouncedly streptospirally coiled, while the last whorl appears to lie in one plane. The last whorl has $7 \frac{1}{2}-9$ chambers. In a few specimens the chambers of the last whorl seem to alternate about its plane of symmetry. The chambers increase moderately in size. The septa are long and have an S-shaped cross-section and are slightly forward-pointing. The ridges are low and strong. They have a rounded cross-section; in a few cases the cross-section assumes a hookshaped appearance in the last chambers. In some other cases the ridges seem to be strongly reduced. Corner fillings are observed with some uncertainty. Thickenings cf the septa occur. The wall consists of carbonate and has a granular microstructure.

Remarks: This species is not identical with any known species. By its internal elements it shows some similarity to E. omphalota RAUSER-ČERNOUSSOva \& ReITLINGER 1936, which, however, is less pronouncedly streptospirally coiled and has a greater breadth.

Endothyra sp. 1 is probably a new species, whose relations to known species are similar to the relations discussed under E. cf. bradyi.

\section{Endothyra sp. 2}

Pl. VIII, fig. 7; pl. IX, figs. 1-2; pl. XVII, figs. 4-5.

Material: Minimum 6 specimens, all in thin-section.

Diagnosis: Pronouncedly streptospirally coiled.

3-4 whorls; 7-9 chambers in the last whorl.

Internal elements: The ridges are small and have in a few cases a triangular, forward-pointing cross-section.

Dimensions: Diameter $0.49-0.65 \mathrm{~mm}$, breadth $0.28-0.40 \mathrm{~mm}$, breadth/ diameter $0.55-0.67$ (?).

Remarks: The specimens examined are more or less poorly preserved. The above diagnosis is an attempt to outline the poorly defined characters of this group of specimens. They seem to show affinity to $E$. cf. bradyi but are here described separately because of their poor condition of preservation and their occurrence in beds which do not contain $E$. cf. bradyi. 
Endothyra convexa regularis RAUSER-ČERNOUSSOVA 1948

Pl. IX, figs. 3-4; pl. XVII, figs. 8-9.

1948. Endothyra convexa var. regularis RAUSER-ČERNOUSSOVA, p. 169, pl. 4, figs. 11-12.

Material: 21 (?) specimens, of which 4 in thin-section.

Diagnosis: Slightly streptospirally coiled.

$2-2 \frac{1}{2}$ whorls; $6-7$ chambers in the last whorl.

No internal elements.

Dimensions: Diameter $0.30-0.49 \mathrm{~mm}$, breadth $0.18-0.32 \mathrm{~mm}$, breadth/ diameter $0.53-0.65$.

Description: The test is small, asymmetric, almost involute and has a depressed umbilical area. The margin is rounded and lobulate. The sutures are clearly depressed and radial. The chambers appear on the outer surface as pronouncedly inflated. The surface of the test is light and even. The aperture is a fairly high fissure, interiomarginal. It is, however, markedly asymmetric, as the apertural face extends from the margin down toward the umbilical area on one side of the test.

The test has $2-2 \frac{1}{2}$ whorls, which are slightly streptospirally coiled. The last $1-1 \frac{1}{2}$ whorls seem, as observed in thin-section, to lie in one plane, while the streptospiral coiling is clearly visible on the surface of the test. The last whorl has 6-7 chambers. The height and the breadth of the chambers increase fairly rapidly. The septa are long, curved and almost radial. The wall consists of carbonate and has a granular microstructure.

Remarks: This form differs slightly from the holotype in being a little smaller and in having fewer whorls, $2-2 \frac{1}{2}$ as compared with the 3 whorls in the holotype.

Stratigraphical distribution:

U.S.S.R.: Middle Visean.

Endothyra aff. costifera Grozdilova \& LeBedeva 1954

Pl. IX, figs. 5-7.

Material: 3 specimens in thin-section.

Diagnosis: The test is oval in horizontal section. The whorls are pronouncedly streptospirally coiled.

4-5 whorls; $81 / 2-9$ chambers in the last whorl. 
Internal elements: The ridges are small except in the last chamber, in which they are fairly large and have a hook-shaped cross-section.

Dimensions: Diameter $0.43-0.67 \mathrm{~mm}$, breadth $0.23-0.32 \mathrm{~mm}$, breadth/ diameter $0.48-0.50$.

Description: The test is asymmetrical, and the last chambers cling to one side of the preceding whorl. The horizontal outline is oval. The test seems to be evolute on both sides. It is fairly flat and has a slight umbilical concavity. The margin is rounded and slightly lobulate. The chambers are slightly inflated and are separated by slightly depressed, not clearly visible sutures. The aperture is a cresent-shaped interiomarginal fissure.

The test has $4-5$ pronouncedly streptospirally coiled whorls. The last whorl has $81 / 2-9$ chambers, which are elongated and which increase only slowly in size. The septa are fairly long, curved, obliquely forward-pointing and showing a tendency to terminal thickening. The ridges are low and broad at the base and often pointed; in the last chamber the ridge is higher and has a hook-shaped cross-section. The wall is fairly thin; it consists of carbonate and has a granular microstructure.

Remarks: This form is very nearly identical with $E$. costifera GrozDILOVA \& LEBEDEVA 1954 (p. 86). The three specimens differ somewhat from one another. Thus one of them (pl. IX, fig. 7) agrees closely with E. costifera while the other two are larger and have shorter septa.

$E$. aff. costifera has a coiling somewhat similar to that of E. paracostifera var. plagia CONIL \& Lys 1964 but differs in the shape of the ridges.

E. costifera is here given as erected by GROzDILOVA \& LeBEDEva in 1954 and not as erected by LIPINA in 1955, since the description is given by the former in 1954 and since there is no reason to assume that LIPINA was responsible for it (cf. Ellis \& MEssina $1940 \mathrm{ff}$.).

\section{Endothyra spp. (F-37) \\ Pl. IX, figs. 8-10.}

Remarks: These three specimens are shown as representatives of a somewhat heterogeneous and indeterminable group of individuals which occur distributed in 8 samples from the lower part of the profile.

Their common characteristics are an oval horizontal section, pronouncedly streptospirally coiled whorls and small ridges; in the last chamber the ridge is high, thin and obliquely forward-pointing. The specimens show in these features some similarity to the above-mentioned $E$. aff. costifera. They differ from one another in size, length and thickness of the septa and thickness of the wall. Also the outer shape of the test varies. 


\section{Endothyra danica n. sp.}

Pl. X, figs. 1-7; pl. XVII, figs. 6-7.

Derivation of the name: The type locality is Danish.

Holotype: D.G.U. catalogue No. 1970-OM-83; pl. X, fig. 1.

Type locality: The boring Ørslev No. 1, D.G.U. file No. 238.502.

Type bed: Claystone and limestone, grey to dark grey. Depth 7780'-7790'.

Material: More than 200 specimens, of which 24 in thin-section.

Diagnosis: A species of the genus Endothyra which has slightly to moderately streptospirally coiled whorls. The septa are long and almost radial.

$3 \frac{1}{2}-4$ whorls; $71 \frac{1}{2}-81 \frac{1}{2}$ chambers in the last whorl.

No internal elements.

Dimensions: Diameter 0.44(0.30)-0.58 mm, breadth $0.24-0.27 \mathrm{~mm}$, breadth/diameter $0.53-0.57$.

Description: The test is slightly asymmetric, being evolute on one side and involute on the other. The umbilical area is s!ightly depressed on both sides. The margin is rounded and lobulate. The sutures do not show clearly; they are slightly depressed and almost radial. On the surface of the test the chambers appear to be only slightly inflated, while in thin-section they show to be more pronouncedly inflated. Also, the sutures are more marked in thinsection. The aperture is fissure-shaped and very low; it is interiomarginal. The apertural face is only slightly shifted relative to the margin of the preceding whorl.

The test has $31 / 2-4$ whorls, which are streptospirally coiled. The plane of coiling for the first 2 whorls tilts about $90^{\circ}$, while for the following whorls it tilts only slightly. The streptospiral coiling appears only faintly in the horizontal section. The height of the whorls increases moderately, while the breadth increases more rapidly. The septa are long, almost radial, S-shaped in cross-section and terminally pointed. The wall is fairly thick; it consists of carbonate and has a granular microstructure.

Remarks: E. danica and small specimens of $E$. cf. bradyi are very similar to each other in their outer characteristics. E. cf. bradyi is, however, more clearly asymmetrical, and its chan.bers are more inflated.

In horizontal section $E$. danica shows a slight affinity to the group $E$. prisca. However, it is larger and has clearly S-shaped septa. Furthermore, the chambers appear to be more inflated than in E. prisca, and the last whorl has relatively fewer chambers. 
Endothyra cf. delepinei CONIL \& LYS 1964

Pl. X, figs. 8-9; pl. XIX, figs. 7-9.

Material: 18 specimens, of which 2 in thin-section.

Diagnosis: Pronouncedly streptospirally coiled.

3-4 whorls; 8 chambers in the last whorl.

Internal elements: The floor of the chambers is covered by a continuous coating, and each chamber has a low ridge. In the last two chambers the ridge is high, strong and pointed.

Dimensions: Diameter $0.48-0.53 \mathrm{~mm}$, breadth $0.28-0.31 \mathrm{~mm}$, breadth/ diameter 0.58 .

Description: The test is pronouncedly asymmetric, the last chambers hanging on one side of the preceding whorl. One side of the test is involute with an umbilical depression, the other side is evolute with a slightly depressed umbilicus. The margin is rounded and lobulate to slightly lobulate. The sutures are depressed and sharply marked. The surface of the test is light and even. The aperture is fissure-shaped, interiomarginal and asymmetric. The fissure is fairly high over the margin, narrowing along one side of the test.

The test has 3-4 whorls, which are pronouncedly streptospirally coiled. In horizontal section the last whorl appears to be planispiral, while it on the surface of the test is seen to be clearly asymmetric. The last whorl has 8 chambers. The size of the chambers increases moderately. The septa are long, curved and obliquely forward-pointing. As to internal elements, there is, at least in the last whorl, on the floor of the chambers a continuous coating with low, rounded ridges. In the two last chambers the ridges are high, strong and pointed. The whorls appear to be oval in horizontal section. The wall is fairly thin; it consists of carbonate and has a granular microstructure.

Remarks: The specimens studied differ from E. delepinei ConIL \& Lys 1964 (p. 182) in having 3-4 whorls instead of $2 \frac{1}{2} 2$. In E. delepinei the height of the last whorl increases more rapidly.

The very strongly developed ridges in the last two chambers distinguish this form from E. similis RAUSER-ČERnoussova \& ReItLinger 1936. Both $E$. cf. apposita and $E$. cf. bradyi have specimens with equally well-developed ridges but without a continuous coating on the floor of the chambers.

The outer morphology of this form shows great similarity to E. aff. prisca, which, however, has narrower whorls, a dark surface of the test and less clearly visible sutures. 
Endothyra michoti spinata n. subsp.

Pl. XI, figs. 1-6; pl. XII, fig. 1; pl. XVIII, figs. 1-2.

Derivation of the name: From spina, which means spine; the spine-shaped cross-section of the marked ridge of the last chamber distinguishes this subspecies from E. michoti (CoNIL \& LYs 1964).

Holotype: D.G.U. catalogue No. 1970-OM-97; pl. XI, fig. 2.

Type locality: The boring Ørslev No. 1, D.G.U. file No. 238.502.

Type bed: Claystone, very calcareous, dark grey, with zones of limestone. Depth 7700'.

Material: More than 330 specimens, of which 21 in thin-section.

Diagnosis: Almost planispiral; the septa of the older whorls are very rudimentary.

5-6 whorls; 9-10 chambers in the last whorl.

Internal elements: A fairly high and thin ridge in the last chamber, and irregular occurrences of small ridges in the older chambers. Corner fillings present.

Dimensions: Diameter $0.90-1.20 \mathrm{~mm}$, breadth $0.36-0.46 \mathrm{~mm}$, breadth/ diameter $0.33-0.42$.

Description: The test is bilaterally symmetrical and evolute. The umbilicus is broad and fairly deep. The margin is broadly rounded and lobulate. The sutures are thin, clearly visible, somewhat depressed and obliquely backwardpointing. The chambers are slightly inflated. The aperture is a low and broad fissure; it is interiomarginal. The outer shape of the test is very regular and simple.

The test has 5-6 whorls; in juvenile specimens often only 3 whorls are observed. They are planispirally coiled, except that the first whorl is tilted $90^{\circ}$ from the plane of symmetry. The following whorls deviate slightly from this plane, so that in axial sections they give an impression of a sigmoid construction. The height of the whorls increases moderately, while the breadth increases more rapidly. There is only a small overlap from one whorl to the preceding one. The last whorl has 9-10 chambers, in juvenile specimens often only 6 . In the last whorl the septa are fairly short or in a part of the whorl even rudimentary. In the older whorls the septa are most usually very rudimentary. The septa are curved and point obliquely forward. The ridges are small and knob-shaped in cross-section and occur irregularly. The last chamber has always, also in juvenile specimens, a high ridge, which usually is disc-shaped and points obliquely forward. In a few cases it has a more pointed and hook-shaped cross-section. Corner fillings are common. The wall consists of carbonate and has a granular microstructure. 
Remarks: This form seems to belong to the genus Endothyra but shows also a number of characters which point to other groups. It has tournayellide features, and $i \hat{\imath}$ thus shows a possible affinity to Septatournayella except for the internal elements. Juvenile specimens are, except for the ridge in the last chamber, very similar to Brunsiina. In horizontal section this form resembles closely the genus Eoendothyranopsis ReItL. \& Rostovz., while the axial section shows such features as in Tournayella DAIN 1953. For the evaluation and determination of this subspecies it is thus very important to have both horizontal and axial sections of both adult and juvenile specimens.

E. michoti spinata differs from E. michoti (ConIL \& LYS 1964) in having a greater diameter and a more pronouncedly planispiral coiling. The fairly high and narrow ridge in the last chamber is a characteristic feature, which distinguishes it from E. michoti.

Endothyra tumula E. J. ZeLLeR 1957 has the same shape of the test as E. michoti spinata. It is, however, considerably smaller than the latter and has strong, low ridges in all the chambers.

Endothyra aff. prisca RAUSER-ČERnOUSSOVA \& REITLINGER 1936 Pl. X, figs. 10-12; pl. XVIII, figs. 3-5.

Material: 79 specimens, of which 13 in thin-section.

Diagnosis: Pronouncedly streptospirally coiled, with a small initial part and a dominating last whorl.

$2 \frac{1}{2}-3 \frac{1}{2}$ whorls; $7 \frac{1}{2}-10$ chambers in the last whorl.

No internal elements.

Dimensions: Diameter $0.30-0.44 \mathrm{~mm}$, breadth $0.17-0.28 \mathrm{~mm}$, breadth/ diameter $0.56-0.64$.

Description: The test is small and is typically asymmetric, being involute on one side and evolute on the other side. It is biconvex. The margin is rounded and lobulate to slightly lobulate. The extent of the chambers across the margin is large, covering the umbilicus on one side of the test and extending across the margin to the umbilicus on the other side, leaving this umbilicus open, however. The sutures are slightly depressed, radial and broad, but do not show clearly. The horizontal outline of the test is oval. The aperture is a very narrow fissure, interiomarginal; it is, however, asymmetrical, extending from the margin of the preceding whorl down on one side of the test.

The test has $2 \frac{1}{2}-3 \frac{1}{2}$ whorls, which are pronouncedly streptospirally coiled. The first couple of whorls are closely coiled, while the last whorl appears more loosely coiled. The last whorl has $71 / 2-10$, usually $8-9$, chambers. The septa are long, radial or slightly forward-pointing, and S-shaped. They are fairly thick; they are broad at the base and pointed. The wall is thick; it consists of carbonate and has a granular microstructure. 
Remarks: This form shows some affinity to the group E. prisca RAUSERĆERnoussova \& Reitlinger 1936 (p. 213), especially to E. prisca var. parva (CONIL \& Lys 1965). The latter is, however, a little smaller and may have internal elements in the form of small ridges. It is possible that the form examined is a new variety of $E$. prisca or a very closely related species.

\section{Endothyra sp. 3}

Pl. X, fig. 13 .

Material: 7 specimens, of which 2 in thin-section.

Remarks: These specimens seem to be related to the above-described $E$. aff. prisca. The streptospiral coiling is more moderate, the wall is not so thick, and the septa are clearly forward-pointing. A closer determination is not possible.

\section{Endothyra sp. (F-13)}

Pl. XII, fig. 2.

Remarks: In three samples from the upper part of the profile a few poorly preserved specimens are found. Neither the outer nor the inner features are well defined. The tests are small and asymmetrical. The coiling is moderately streptospiral and the septa are almost radial. The ridge are slightly developed.

\section{Endothyra recta LIPINA 1955}

Pl. XII, figs. 3-11; pl. XVIII, figs. 6-11; pl. XIX, figs. 1-3.

1955. Endothyra recta Lipina, p. 60, pl. 7, figs. 4-8.

1964. Plectogyra recta (LiPINA) - ConiL \& Lys, p. 211, pl. XXXV, figs. 703-710.

1969. Endothyra recta LiPINA - ConIL et al., p. 59, pl. II, fig. 20.

Material: More than 80 specimens, of which 18 in thin-section.

Diagnosis: The test is fairly pronouncedly to moderately streptospirally coiled.

4-6 whorls; 10-13 chambers in the last whorl.

Internal elements: Knobs are common; in the last chambers they usually take the form of spines or hook-shaped spines.

Dimensions: Diameter $0.37-0.57 \mathrm{~mm}$, breadth $0.22-0.32 \mathrm{~mm}$, breadth/ diameter 0.47-0.73. 
Description: The test is medium-sized, asymmetrical and has an oval to circular horizontal outline. One side of the test is evolute without an umbilical depression, while the other side is slightly evolute to involute with an elongated concavity. The margin is rounded and slightly lobulate. The chambers usually are only slightly inflated; their extent across the margin is very large. The sutures show clearly and are slightly depressed; they are almost radial, but are across the margin slightly backward bent. The surface of the test is dark and even. The aperture is a fairly short fissure, interiomarginal. It is scmewhat asymmetric, as the apertural face is somewhat shifted down on the side of the preceding whorl.

The test has 4-6 whorls, which are streptospirally coiled. Because of the large extent of the chambers across the margin the whorls appear, when seen in horizontal section, only slightly streptospiral or nearly planispiral; this is the case especially for the youngest whorls. In axial section, however, more whorls are seen than would be expected from this. On the surface of the test it is, however, clearly apparent that the tilting of the whorls is constant and fairly strong. The last whorl has 11-12 chambers, less commonly 10 or 13. The height of the whorls increases fairly slowly. The septa are fairly long, almost straight and obliquely forward-pointing. The internal elements are developed as small knobs, perhaps ridges. In the last couple of chambers they are usually spine- or hook-shaped. The wall is fairly thin; it consists of carbonate and has a granular microstructure.

Remarks: The outer shape of the test is very variable (see pl. XVIII, figs. 6-11; pl. XIX, figs. 1-3), ranging from a nearly spherical to a flattened oval shape. In spite of the fact that the study is based on a fairly large material it does not seem possible to subdivide it sharply into groups. In the grinding of the individual specimens the differences are made still more indistinct.

The internal elements are in the above description with some uncertainty called knobs or spines. Even though the axial sections seem to confirm this, the characters of the internal elements are nevertheless not fully elucidated. A few axial sections show some affinity to the genus Dainella BražNIKova 1962 in that the internal elements may have a chomata-like appearance. A few specimens (pl. XII, figs. 3 \& 9) show great similarity to E. paracostifera var. multicamerata LIPINA 1955.

The specimens studied may with certainty be referred to E. recta. It is, however, an open question whether this form ought to be considered as a group of varieties.

\section{Stratigraphical distribution:}

Belgium: Visean 1a, 2a \& 2b.

U.S.S.R.: Upper Tournaisian to Lower Visean. 


\section{Endothyra sp. 4 \\ Pl. XII, figs. 12-13; pl. XIX, figs. 4-6.}

Material: 5 specimens, of which 4 in thin-section.

Diagnosis: Streptospiral with an approximately planispiral last part. 5-6 whorls; 13-14 chambers in the last whorl.

Internal elements: Well-developed knobs, which are often pointed. In the last chamber a spine.

Dimensions: Diameter $0.51-0.71 \mathrm{~mm}$, breadth $0.27-0.28 \mathrm{~mm}$, breadth/ diameter $0.39-0.50 \mathrm{~mm}$.

Remarks: A few of the specimens described under E. recta show some affinity to this form. In general, however, Endothyra sp. 4 differs from $E$. recta in being large and flat, in having a light surface of the test and in having more chambers in the last whorl. It seems also to be more pronouncedly streptospirally coiled in the older whorls. Because of the large extent of the chambers across the margin it is also in this form difficult to estimate the degree of tilting of the whorls. The entire last whorl lies, however, in one plane.

The character of the internal elements is similar to that described under the remarks to E. recta. Also Endothyra sp. 4 shows in axial section some affinity to the genus Dainella.

\section{Endothyra sp. 5}

Pl. XIII, fig. 1.

Diagnosis: Fairly pronouncedly streptospirally coiled.

3 whorls; $9 \frac{1}{2}$ chambers in the last whorl.

No internal elements.

Dimensions: Diameter $0.60-0.98 \mathrm{~mm}$, breadth $0.60 \mathrm{~mm}$.

Remarks: A number of specimens of this form are found in the uppermost part of the profile. The test is large, asymmetric and has fairly strongly inflated chambers, It is usually fairly poorly preserved and not particularly well-defined. Identification to species does not seem possible.

\section{Endothyra sp. 6}

Pl. XIII, figs. 2-3.

Material: 2 specimens in thin-section.

Diagnosis: The test is disc-shaped and planispiral with streptospiral initial part.

6 whorls, of which $2-2 \frac{1}{2}$ are planispiral; $9-10$ chambers in the last whorl. Internal elements: A thir and fairly high ridge in the last chamber. 
Dimensions: Diameter 0.36 and $0.45 \mathrm{~mm}$, breadth of the last whorl 0.11 $\mathrm{mm}$, breadth/diameter 0.31 .

Description: The test is disc-shaped, evolute and oval in horizontal section. The umbilicus is broad, depressed and has a central hump which marks the extent of the streptospiral part. The margin is rounded and lobulate. The chambers are inflated and separated by thin and clearly visible sutures. The aperture is fissure-shaped and fairly low, interiomarginal.

The first 31/2-4 whorls are pronouncedly streptospirally coiled. The septa appear to be rudimentary in this part of the test. Its breadth is greater than the breadth of the last whorl. The planispiral part consists of $2-2 \frac{1}{2}$ whorls, whose height increases slowly. The length of the chambers is larger than their height. The septa are short and are obliquely forward-pointing. The last chamber has a thin, forward-pointing ridge, or possibly spine. The earlier chambers show faint indications of very small ridges with knob-shaped crosssections. The wall consists of carbonate and has a granular microstructure.

Remarks: Except for the internal elements present this form shows the same characters as the genus Septabrunsiina. The shape of the entire test is alien to the genus Endothyra and is not found described for any other species. However, E. discoidea GIRTY 1915 seems to have similar characteristics. It has a larger number of chambers in the last whorl, and the breadth of the test (see GIRTY, 1915, pl. 10, figs. 11-12) is relatively greater. Furthermore it seems to lack a central hump in the umbilicus.

In its outer morphoiogy Endothyra sp. 6 is almost identical with Septabrunsiina spissusvoluta $\mathrm{n}$. sp. In horizontal section it differs from the latter in the presence of internal elements and in the whorls being more loosely coiled. Axial sections of Endothyra sp. 6 are not known but are presumed to be nearly identical with axial sections of $S$. spissusvoluta.

\section{Endothyra spp. (F-29 \& F-44) \\ P1. XIII, figs. $4-7$.}

Remarks: These specimens are shown here as representatives of two small groups of very poorly preserved tests, which occur in the zone poor in fossils in the middle of the profile.

Genus Paraendothyra Chernysheva 1940

Paraendothyra cummingsi (CONIL \& LYs 1964)

P1. XIII, fig. 8.

1964. Plectogyra cummingsi ConIL \& Lys, p. 181, pl. XXVII, fig. 538.

1969. Paraendothyra cummingsi (ConIL \& Lys) - ConIL et al., p. 59, pl. II, fig. 16. 
Material: 2 specimens in thin-section.

Diagnosis: Almost planispiral (?).

2-3 whorls; 71/2 chambers in the last whorl.

The basal part of the septa is fairly low and very strong.

Dimensions: Diameter 0.60-0.75 mm.

Remarks: These two specimens differ from $P$. nalivkini CHERnysheva 1940 in being a little broader and more plump. In the last chambers the basal part of the septa is lower and stronger. All the other characters show so great agreement between the two species that they are difficult to distinguish.

Stratigraphical distribution:

Belgium: Visean 1a \& 1b.

\section{Paraendothyra nalivkini CHERnYSHeva 1940}

Pl. XIII, figs. 9-10.

1940. Paraendothyra nalivkini Chernysheva, p. 129, pl. 1, figs. 1-2; pl. 2, fig. 4 ; text-figs. $2-5$.

Material: 2 specimens in thin-section.

Diagnosis: Almost planispiral.

3 whorls; $7 \frac{1}{2}$ chambers in the last whorl.

In the last 3 chambers the basal part of the septa is high and narrow; in the older chambers it is low and strong.

Dimensions: Diameter $0.68-0.70 \mathrm{~mm}$, breadth $0.26-0.29 \mathrm{~mm}$, breadth/ diameter $0.38-0.41$.

Remarks: These two specimens are very nearly identical with the holotype. They differ from it in having a round aperture and in their relation breadth/ diameter being a little smaller. Furthermore the overlap from one whorl to the preceding one is a little smaller than shown in the drawing in CHERNYSHEVA (1940, text-fig. 3). Concerning the relation between this species and $P$. cummingsi the reader is referred to the remarks given under the latter species.

Stratigraphical distribution:

U.S.S.R.: Middle Tournaisian. 
Subîamilia Haplophragmellinae ReITLINGER 1959

Genus Haplophragmina ReITLINGER 1950

Haplophragmina loeblichi CONIL \& LYS 1968

Pl. XIV, figs. 10-11; pl. XIX, fig. 10.

1968. Haplophragmina loeblichi ConIL \& Lys, p. 504, pl. IV, figs. 54-57.

Material: 9 specimens, of which 5 in thin-section.

Diagnosis: Almost planispiral initial part. The uniserial part is conical.

$1-1 \frac{1}{2}$ whorls; $4-4 \frac{1}{2}$ chambers in the last whorl; 4 chambers in the uniserial part.

Dimensions: Diameter $0.27-0.41 \mathrm{~mm}$, maximal breadth of the uniserial part $0.46 \mathrm{~mm}$, maximal length $1.09 \mathrm{~mm}$.

Description: The test is fairly small and has a nearly symmetrical coiled initial part. In large specimens the uniserial part is conical by reason of a rapid increase in the breadth of the chambers. The margin is rounded and lobulate. The chambers are inflated and are separated by clearly visible sutures. The surface of the test is dark and uneven. The aperture is terminal. In large specimens it is cribrate, while in the smaller specimens it is simple.

The initial part has $1-1 \frac{1}{2}$ whorls, which are nearly planispiral. The last whorl has $4-4 \frac{1}{2}$ chambers. The septa are rudimentary in the initial part but only strongly reduced in the uniserial part. The wall consists of carbonate and has a granular microstructure; inclusions of large grains occur.

Stratigraphical distribution:

Belgium: Visean 2a (lower).

Familia Ozawainellidae Thompson \& Foster 1937

Genus Endostaffella Rozovskaya 1961

Endostaffella ? sp. 1

Pl. XIII, figs. 11-14; pl. XIV, figs. 1-3; pl. XIX, fig. 11.

Material: About 50 specimens, of which 10 in thin-section.

Diagnosis: The test is oval or slightly nautiloid in axial section. Streptospiral.

4 whorls; 10-12 chambers in the last whorl.

Internal elements: The chomata (pseudochomata) are slightly developed. Dimensions: Diameter $0.34-0.57 \mathrm{~mm}$, breadth $0.22-0.33 \mathrm{~mm}$.

Description: The test is medium-sized, nearly bilaterally symmetrical and usually evolute on both sides. The umbilical area is slightly depressed on both sides or on one side only. The margin is rounded to slightly rounded and very slightly lobulate. The sutures do not show clearly and are slightly 
depressed. The surface of the test is light and fairly even. The aperture appears to be fissure-shaped, interiomarginal.

The test has 4 whorls, which are streptospirally coiled. The last whorl has 10-12 chambers. The extent of the chambers across the margin is large, and as a consequence the test will in horizontal section usually appear to be more planispiral than it actually is. The septa are short and obliquely forward-pointing. The chomata (pseudochomata) are slightly developed. The wall is fairly thin; it consists of carbonate and has a granular microstructure.

Remarks: The specimens studied are, as is usual for the uppermost part of the profile, very poorly preserved. A closer determination is not possible. They are with some uncertainty referred to the genus Endostaffella, as a few of the specimens (see pl. XIV, fig. 1) show some affinity to the genus Dainella Brožnikova 1962. Another specimen (see pl. XIV, fig. 2) shows affinity to the genus Eoparastaffella VDOvEnko 1954. It is possible that the above-described group of specimens represents more than one species. They are selected primarily on the basis of the outer morphology of the test and secondarily on the basis of horizontal and axial sections.

\section{Endostaffella ? sp. 2 \\ P1. XIV, figs. 4-7; pl. XIX, fig. 12.}

Material: About 30 specimens, of which 10 in thin-section.

Diagnosis: The test is oval in axial section. Streptospiral.

3-5 whorls; 11-14 chambers in the last whorl.

Internal elements: The chomata (pseudochomata) are slightly developed.

Dimensions: Diameter $0.38-0.65 \mathrm{~mm}$, breadth $0.20-0.22 \mathrm{~mm}$.

Description: The test is biconvex and is evolute on both sides. The margin is rounded to broadly rounded and is slightly lobulate. The sutures show fairly clearly and are slightly depressed. The surface of the test is light and fairly even. The aperture appears to be fissure-shaped; it is interiomarginal.

The test has $3-5$, usually 4 whorls, which are streptospirally coiled. By reason of the large extent of the chambers across the margin the test appears to be nearly planispiral in horizontal section. The last whorl has 11-14 chambers. The height of the whorls increases fairly rapidly. The chomata (pseudochomata) are slightly developed. The wall consists of carbonate and has a granular microstructure.

Remarks: Both this form and Endostaffella? sp. 1 are poorly preserved and difficult to determine. They are with some uncertainty referred to the genus Endostaffella. Among other things the planispiral appearance of horizontal sections of this form makes probable at least that it belongs to the family Ozawainellidae. 


\section{Genus Eostaffella RAuSER-ČERnoussova 1948}

\section{Eostaffella sp. 1}

Pl. XIV, figs. 8-9; pl. XX, figs. 1-2.

Material: 6 specimens, of which 2 in thin-section.

Diagnosis: Lenticular with slightly marked umbilicus. Nearly planispiral with streptospiral initial part.

4 whorls; 8 chambers in the last whorl.

Internal elements: The chomata (pseudochomata) are fairly well-developed.

Dimensions: Diameter $0.80-0.87 \mathrm{~mm}$, breadth $0.39-0.44 \mathrm{~mm}$, breadth/ diameter $0.48-0.51$.

Description: The test is large, slightly asymmetrical, evolute on one side and involute on the other. The umbilical area is a little depressed on both sides. The margir is slightly rounded and lobulate. The chambers are inflated and separated by broad, depressed and almost radial sutures. The aperture is a short and high fissure, interiomarginal and a little asymmetrically placed relative to the preceding whorl.

The test has 4 whorls, which in the initial part are pronouncedly streptospirally coiled and in the rest of the test nearly planispiral. The last whorl has 8 chambers. The septa are long, curved, forward-pointing and terminally thickened. The chomata (pseudochomata) are fairly well-developed and leave medially only a small opening. The wall is fairly thick; it consists of carbonate and has a granular microstructure.

Remarks: The wall is presumably to be considered as consisting of two layers, since the otherwise homogeneous wall is divided up by a monogranular layer of black grains (pyrite?). On the inner side the wall is covered by a thin, brownish organic film.

Eostaffella sp. 1 differs only slightly from $E$. parastruvei RAUSER-ČERNoussova 1948. In the form studied the opening between the chomata is smalier, and the initial part appears to be more pronouncedly streptospirally coiled. 


\section{ACKNOWLEDGMENTS}

The present work has been made at the suggestion and with the support of Dr. Leif Banke Rasmussen, head of the Pre-Quaternary Department, who has kindly made available material to the author.

During a five days visit to Professor RAPHAËL CONIL at the Université de Louvain in March 1970, I had the opportunity to study his type collection of Carboniferous foraminifera and to discuss my material with him very thoroughly. I herewith wish to express my best thanks to Professor RAPHAËL ConIL for the valuable help which he has rendered me in this and other ways.

Miss Kirsten Andersen and Mrs. Helle Christensen have made the drawings and Mr. O. NeErgaArd Rasmussen has done the photographic work. The manuscript has been translated to English by Mr. Svend HenrikSEN, geophysicist, and typed by Mrs. KirSTEN SPERLing. 


\section{DANSK SAMMENDRAG \\ NEDRE KARBONE FORAMINIFERFAUNAER FRA BORINGEN \\ ØRSLEV NR. 1, FALSTER, DANMARK}

\section{INDLEDNING}

Boringen $\emptyset$ rslev nr. 1, D.G.U. arkiv nr. 238.502, er beliggende på Øen Falster på koordinaterne $54^{\circ} 46^{\prime} 55^{\prime \prime} \mathrm{N}$ og $11^{\circ} 59^{\prime} 02^{\prime \prime} \varnothing$ for Greenwich (se text-fig. 1 og 2), og er udført i perioden november 1967 til januar 1968. Lokalitetens terrænkote er $+54^{\prime}(+16,4 \mathrm{~m})$, og koten for Kelly Bushing $+74^{\prime}(+22,7 \mathrm{~m})$. I det følgende er alle dybder angivet i engelske fod under Kelly Bushing.

Under aflejringer af zechstein alder er der gennemboret en ca. 750' mægtig serie af overvejende rødlige lersten, siltsten og sandsten af ubestemt alder (rotliegendes eller $\emptyset$ vre karbon). Underlejrende disse lag, fra dybden $6740^{\prime}$ og til boringens slutdybde $8440^{\prime}$, findes stærkt fossilf $\varnothing$ rende lag af grålige lersten, mergelsten og kalksten. I denne lagserie, 6740'-8440' er boringen overvejende udført som skylleboring. Kun to afsnit er kærneborede: 6850'-6898' 6" (kærne nr. 1) og 7686'-7746' (kærne nr. 2). På grundlag af biostratigrafiske data kan lagserien henføres til nedre karbon. Da aflejringer af karbon alder ikke tidligere er påvist i Danmark, er dette af betydelig interesse for dansk geologi. Kærne nr. 2 er da også allerede i januar 1968 henført til nederste viséen af O. BRUUn CHRISTENSEN (upubl. rapp., jf. 1971). Ved denne foreløbige undersøgelse og bestemmelse er der overvejende korreleret til de tyske fund på Rügen.

I nærværende afhandling er foraminiferfaunaen beskrevet. Foraminifererne er det dominerende element i de oftest righoldige mikrofaunaer. I $\varnothing$ vrigt indeholder lagserien vekslende mængder af ostracoder, koraller, crinoider, echinider, brachiopoder, gastropoder og lamellibranchiater. Endelig skal det nævnes, at blandt de forekommende plantefossiler vil FINN BERTELSEN analysere sporeindholdet i udvalgte afsnit.

\section{LITHOLOGI}

Sedimenterne er beskrevet af Th. ERIKSEN og E. Stenestad på grundlag af tørrede cuttings, der er separerede fra den rå skylleprøve ved opslæmning og dekantering af boremudderet. Til st $\varnothing$ tte for beskrivelsen i de respektive afsnit er kærnerne nr. 1 og 2 anvendt. Nedenstående beskrivelse og zonering af de 
lithologiske enheder er korrigeret ved hjælp af Schlumberger Logs: Interval Transit Time Log, Gamma Ray Log, Neutron Log og Resistivity Log.

Beskrivelse af sedimenterne i det unders $\varnothing$ gte afsnit (jf. pl. XXII):

6740'-6770': Kalksten (dolomitisk), rødliggrå; samt kalksten, stærkt lerholdig, mørkebrun.

6770'-6810': Kalksten (dolomitisk), lysegrå; med mørkebrune, lerede lag. Indholdet af ler synes at tiltage nedefter.

6810'-6930': Kalksten (dolomitisk), grålig og brunliggrå.

6930'-7250': Mergelsten, ofte sandet, grå-mørkegrå; med aftagende kalkindhold nedefter.

7100'-7250': Vekslende med sandsten, lysegrå og lys rødliggrå, kalkholdig.

7250'-7280': Kalksten (dolomitisk), grå-lysegrå. Midt i dette afsnit findes en tynd zone med lersten, fed, skifret, mørkegrå, kalkholdig.

7280'-7510': Vekslende serie af kalksten (dolomitisk) og mergelsten, gråmørkegrå, samt sandsten, grå-lysegrå, stærkt kalkholdig.

7510'-7650': Vekslende serie af sandsten, grå-lysegrå, kalkholdig og mørkegrå kalksten (dolomitisk).

7520'-7530': Oolitisk kalksten.

7650'-8057': Lersten (mergelsten), grå-mørkegrå og kalksten, grå-mørkegrå.

8057'-8440': Kalksten, grå-mørkegrå, med lersten (mergelsten), grå-mørkegrå.

Denne lagserie kan inddeles i tre afsnit: $6740^{\prime}-6930^{\prime}, 6930^{\prime}-7650^{\prime}$ og $7650^{\prime}$ -8440 '.

I det $\varnothing$ verste afsnit, $6740^{\prime}-6930^{\prime}$, findes ret massive kalksten af vekslende farve; de synes at være dolomitiske. I enkelte intervaller, 6740'-6770' og omkring 6810', forekommer mindre indslag af en leret og mørkebrun kalksten. Denne serie af kalksten er antagelig aflejret under ret rolige og konstante forhold. Da kærne nr. 1 falder indenfor dette afsnit, gengives følgende forkortede beskrivelse efter O. Bruun Christensen \& E. Stenestad (jf. Christensen, 1971):

Karne $n r .1,6850^{\prime}-6898^{\prime} 6^{\prime \prime}$ :

Kalksten, dolomitisk, rødbrun og gråbrun, krystallinsk og hård. Laghældningen er $10^{\circ}-15^{\circ}$. R $\varnothing$ de og grønne slirer og pletter er almindelige. Stylolitlignende strukturer forekommer. Ved $6854^{\prime} 6^{\prime \prime}$ og $6868^{\prime}$ findes cmtykke lag af mørk r $\varnothing$ dbrun lersten. Kalkstenen er mange steder gennemsat af sprækker og harniskflader, äer ofte er calcitcementerede. Disse fænomener, samt udtværede jerniltepletter, tyder på at bevægelser har fundet sted efter sedimentationen. 
Et tyndslib fra 6861'5" (pl. XX, fig. 3) bekræfter ovenstående beskrivelse af kærne nr. 1.

Det bør understreges, at den målte laghældning i både kærne nr. 1 og 2 ikke kan betragtes som den faktiske laghældning. Borehullets afvigelse fra lodlinien er ved dybden 7060' målt til $6^{\circ}$ og ved $7135^{\prime}$ til $31^{\prime} 2^{\circ}$.

Det midterste afsnit, 6930'-7650', er en stærkt vekslende serie af kalksten, mergelsten, lersten og sandsten. Grå til mørkegrå mergelsten er den dominerende bjergart i intervallet 6930'-7250'; under 7100' dog vekslende med lysegrå og r $\varnothing$ dliggrå lersten og sandsten. Som helhed er lerindholdet stigende nedefter i 6930'-7250'. Intervallet 7250'-7510' domineres af grålige (dolomitiske) kalksten, med mindre interkalationer af mergelsten og sandsten. Omkring 7260'-7270' findes en tynd zone med fed, mørkegrå lersten, der er kalkholdig og indeholder plantefossiler. Den nederste del af afsnittet, 7510'-7650', er en hastigt vekslende lagserie med sandsten, kalksten og oolitiske kalksten. Det er vanskeligt at fastslå tykkelsen af de enkelte lag, men i skylleprøverne veksler bjergartssammensætningen med intervaller på $20^{\prime}-30^{\prime}$. Aflejringen af denne lagserie må have fundet sted under ret urolige og skiftende forhold, der antagelig skyldes tektoniske bevægelser i området. Der er i det mindste i to perioder tilf $\varnothing \mathrm{rt}$ bassinet grovkornet materiale, således som de mange interkalationer af sandsten i afsnittene $7100^{\prime}-7250^{\prime}$ og $7510^{\prime}-7650^{\prime}$ vidner om. Foruden disse, de marine kalksten og mergelsten antyder den mørkegrå lersten med plantefossiler, i afsnittet 7260'-7270', tilstedeværelsen af et tredie sæt aflejringsbetingelser.

Det neders`e afsnit, 7650'-8440', er ret homogent og består af grå til mørkegrå kalksten og lersten (mergelsten). Der er jævn overgang mellem de to bjergarter, idet kalkstenen ofte er stærkt lerholdig og lerstenen stærkt kalkholdig. Den $\varnothing$ vre del af denne lagserie er præget af lersten (mergelsten), medens kalkstenen er næsten enerådende under 8057'. Omkring 7680' og $7740^{\prime}$ er der fundet små indslag af kul. Som det fremgår af beskrivelsen af kærne nr. 2 (se nedenfor), veksler de marine lag med kalkfrie og planteførende lag på et par meters tykkelse. På lagflader af marine lag ses ofte koncentrationer af makrofossiler, der kan tolkes som sammenskyllede. Denne vekslen mellem marine og brakke lag, der antages at præge den $\varnothing$ vre del af afsnittet $\left(7650^{\prime}-8057^{\prime}\right)$, må betegnes paralisk (jf. CHRISTENSEN, 1971), der er en udbredt facies i nedre karbon i Nordeuropa. Den nedre del af afsnittet $\left(8057^{\prime}-8440^{\prime}\right)$ synes i højere grad at være præget af marine aflejringer.

Beskrivelsen af kærne nr. 2 gengives i forkortet form efter O. BRUUN Christensen (jf. Christensen, 1971):

Karne nr. 2, 7686'-7746':

7686'-7720': Lersten og lerskifer, gråsort og mørkegrå, stærkt kalkholdig. Decimeter tykke partier af hård, mørkegrå kalksten, rig på pigge efter 
brachiopoder, coralliter og rugose koraller. Brachiopoder findes i hele lagserien. Laghældning $3^{\circ}-7^{\circ}$.

7720'-7727': Lersten, ofte svagt sandet, mørkegrå til gråsort, kalkfri, pyritholdig, mer plantefossiler.

7727'-7738': Lersten, delvis skifret, delvis hård og kalkstensagtig, gråsort, kalkholdig. Zoner med koralfragmenter, pigge fra brachiopoder og crinoidstilke.

$7738^{\prime}-7743^{\prime} 6^{\prime \prime}$ : Lerskifer, ofte løst sammenhængende, gråsort, kalkholdig, med pyrit. Mindre partier med koralfragmenter, samt pigge og skaller af brachiopoder. Ved $7739^{\prime} 6^{\prime \prime}$ glanskulimprægneret, st $\varnothing$ rre plantefossilaftryk. $7743^{\prime} 6^{\prime \prime}-7745^{\prime} 6^{\prime \prime}$ : Lersten, noget skifret, men overvejende hård og kalkholdig, gråsort. Få planterester. Tynde, lyse bånd med rugose koraller og pigge af brachiopoder; pyritholdig. Laghældning $3^{\circ}-5^{\circ}$.

Fra kærne nr. 2 er der fremstillet tyndslib af bjergarterne fra følgende

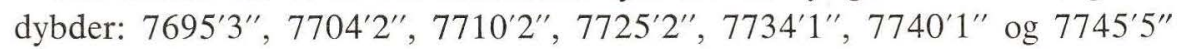
(ji. pl. XXI, fig. 1-2). I alle disse tyndslib, undtagen 7725'2", må bjergarten betegnes mergelsten ofte med et ret stort indhold af kvarts. Carbonatmineraler forekommer som velafgrænsede korn i siltfraktionen, omgivet af lermineraler og en del organisk materiale. Donne struktur bevirker, at bjergarten fremtræder meget mørk og ret løs, således at den ved en makroskopisk iagttagelse kan tolkes som en stærkt kalkholdig lersten. Tyndslibet fra 7725'2" domineres af kvartssilt med underordnet indhold af lermineraler og carbonat. Det vil ikke være rigtigt at drage slutninger vedrørende hele afsnittet, 7650'$8440^{\prime \prime}$, ud fra disse tyndslib, men det synes rimeligt at antage, at det store lerindhold, især i lagserien over 8057', kan skyldes mergelsten af ovenfor nævnte type.

Det bør bemærkes, at kalkstenene i hele den unders $\varnothing$ gte serie i st $\varnothing$ rre eller mindre grad er dolomitiske. En opløsning i $10 \% \mathrm{HCl}$, endda ofte under opvarmning, foregår ret trægt.

\section{MATERIALER OG METODER}

Som omtalt ovenfor er den overvejende del af det unders $\varnothing$ gte interval skylleboret, mens kun to afsnit, 6850'-6898' $6^{\prime \prime}$ og 7686'-7746', er kærneboret. I de skylleborede afsnit er der under boringen udtaget prøver med 10 fods intervaller. Disse er efter nedbrydning med benzin og kogende vand vasket over en sigte med maskevidden 0,1 mm. Kærneprøverne har efter en let knusning gennemgået samme proces. Takket være denne behandling, og især borekronens nedknusning af bjergarterne til cuttings på 1-2 mm, er et ret stort antal mikrofossiler blevet frigjort fra de ofte hårde bjergarter. Til undersøgelse af foraminiferfaunaen er 59 skyllepr $\varnothing v e r$ og 7 kærneprøver udvalgt. 
Kærneprøverne samt ca. 2 skylleprøver pr. 100' lagserie er sorteret grundigt, således at hele faunaen er repræsenteret i de tilsvarende præparater. For at kunne beskrive de mere sjældne foraminiferer er der fra de фvrige skylleprøver udtaget udvalgte arter. De to former for sortering er markeret ved de respektive prøver på tavle XXII, idet de selektivt sorterede prøver ikke viser faunaens sammensætning. Til bedømmelse af bjergartens karakter og fossiltætheden er der fremstillet ni tyndslib fra kærnepr $\varnothing$ ver (se s. 72 og 73). Tyndslibene fra kærne nr. 2 viser en god overensstemmelse med de resultater, der kendes fra slæmmerester af kærneprøver og skyllepr $\varnothing v e r$, medens tyndslibet fra kærne nr. 1 afslører en uventet stor fossiltæthed og artsrigdom. Dette viser, at ved arbejdet med skyllepr $\varnothing v e r$ hårde kalksten b $\varnothing \mathrm{r}$ vurderingen af faunaerne foretages med forsigtighed, idet ovennævnte metoder ikke altid formår at frigøre mikrofossilerne.

Ved fremstilling af tyndslib af foraminifererne er den enkelte skal indlejret i Lakeside, en kunstharpiks. Slibningen, der sker under mikroskop, foretages med en glasplade, der er gjort ru ved hjælp af karborundumpulver. Som smøremiddel anvendes vand, således at hele processen kan følges i mikroskopet og alle skalelementer iagttages i hele skallens udstrækning. Ved opvarmning af Lakeside'n kan denne gentagne gange gøres flydende, således at skallen kan drejes i den $\varnothing$ nskede stilling. Til brug ved denne unders $\varnothing$ gelse er der fremstillet 321 tyndslib.

Til studier af kammerarrangementet hos Palaeospiroplectammina diversa og »Palaeospiroplectammina mellina er der fremstillet flusspatpræparater af isolerede skaller ved følgende metode: Skalvæggen omdannes til flusspat, når skallen henligger i en $40 \%$ flussyre i to uger. Derefter bades den i alkohol og indlejres i glycogel. Skalvæggen er ved denne behandling blevet så gennemskinnelig, at de brune hinder, der beklæder dens inderside, kan iagttages, og det er derved muligt at bedømme kamrenes indbyrdes placering. Desværre har det vist sig umuligt at fremstille brugbare fotografier af sådanne præparater.

\section{FORAMINIFERFAUNAERNE}

Foraminifererne i den unders $\emptyset$ gte lagserie fordeler sig på 48 former, hvoraf kun 13 er bestemt til art. Dertil kommer 9 der er bestemt med nogen usikkerhed, og 4 der er opstillet som nye. De resterende er anført med åben nomenklatur.

Som det ses på tavle XXII er afsnittet inddelt i fire faunizoner, benævnt I-IV (yngste-ældste). Denne zoneinddeling må først og fremmest betragtes som en praktisk måde at beskrive faunaen på, idet den enkelte zones vertikale udstrækning ikke kan afgøres med sikkerhed. Ved vurdering af et materiale fra skylleprøver må det gøres klart, at man ikke har nogen vished for, at mikrofossilerne stammer fra det niveau, hvori de er fundet. Under 
borearbejdet er der risiko for nedfald fra alle lag mellem den aktuelle dybde og den ovenover placerede casing. I boringen Ørslev nr. 1 er den sidste casing ført ned til 5994'. Der er således mulighed for nedfald fra hele lagserien under denne dybde. Hvis skylleprøver repræsenterer lettere konsoliderede bjergarter, kan det højeste niveau, hvor mikrofossilerne findes, normalt regnes for deres $\emptyset$ vre grænse i lagserien. I så hårde kalksten, som findes i intervallet 6740'-6930', er en sådan afgrænsning ikke sikker (se s. 74). Grundet disse fejlkilder er det anset for meningsløst at angive den kvantitative fordeling af de enkelte arter, og på tavle XXII er deres forekomst derfor kun markeret med et $\gg+\ll$. Ved efterfølgende vurdering af det unders $\emptyset$ gte materiale er mængden af nedfald s $\varnothing$ gt sk $\varnothing$ nnet på grundlag af den enkelte arts relative hyppighed og karakteren af det sediment, der eventuelt sidder fasthæftet på skallerne.

Zone I: Denne zone omfatter prøverne nr. 2-7 (6780'-6945'). Zonens udstrækning svarer næsten til mægtigheden af de massive, dolomitiske kalksten i den $\varnothing$ vre del af den undersøgte lagserie; dog således at prøve nr. 7 ligger umiddelbart under kalkstenens nedre grænse.

Faunaen er domineret og karakteriseret af former tilh $\phi$ rende familien Ozawainellidae, Endostaffella? sp. 1 og 2. Slægten Endothyra er repræsenteret med en række arter som Endothyra sp. (F-13), E. aff. costifera, E. sp. 5, $E$. cf. delepinei, E. convexa regularis og $E$. sp. 1 (?), hvoraf de tre sidste kun er fundet i zonens nederste del. Endothyra sp. (F-13) og E. sp. 5 er almindelige, medens de $\varnothing$ vrige Endothyra arter kun er sparsomt repræsenteret. Tetrataxis cf. pressulus er kun fundet i to eksemplarer i prøve nr. 7. Ligeledes er Brunsiina spirillinoides repræsenteret med to eksemplarer fordelt på prøverne nr. 4 og 7. I et tyndslib af bjergarten fra kærne nr. 1, 6861'5" (prøve nr. 4), er enkelte eksemplarer af Brunsiina pseudopulchra, »Palaeospiroplectammina mellina, Palaeospiroplectammina venusta, $P$. aff. tchernyshinensis og E. aff. costifera iagttaget.

Foraminifererne i zone I er ret dårligt bevaret og ikke særligt rigt repræ-

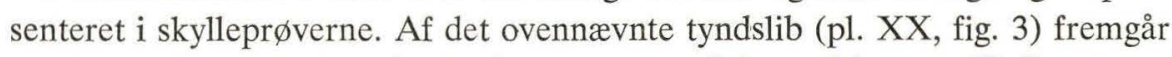
det imidlertid, at fossiltætheden kan være stor i denne bjergart. Skyllepr $\varnothing v e r-$ nes fauna er således ikke repræsentativ, men må sammenholdes med faunaen i dette tyndslib.

Zone II: Denne zone omfatter prфverne nr. 8-29 (6945'-7695'), der er udtaget i den vekslende serie af kalksten, mergelsten og sandsten. Pr $\varnothing$ verne er oftest meget fossilfattige, således at mange arter kun forekommer med et enkelt eksemplar i prøven. Enkelte prøver, nr. 20, 23 og 25, er helt fossilfrie. Foraminifererne er ofte meget dårligt bevarede, især i prøverne nr. 13-15.

Denne zones $\emptyset$ vre grænse er lagt, hvor Palaeospiroplectammina diversa første gang optræder. Umiddelbart under dette niveau tynder det ud i antallet af de former, der forekommer i lagserien derover. Denne udtynding i antallet er taget som indicium på, at forekomsten skyldes nedfald. På dette 
grundlag er det antaget, at der kun er et meget lille artsfællesskab mellem zone I og II. Endothyra cf. delepinei, E. sp. 1 og »Palaeospiroplectammina mellina tiltager så tydeligt i zone II, at de også må regnes til zone II. Tetrataxis cf. pressulus forekommer i så lille et antal, at den ikke med sikkerhed kan placeres, men den antages også at forekomme i zone II, såvel som zone III (?) og IV. De фvrige former fra zone I, undtagen Brunsiina spirillinoides der også forekommer i zone III og IV, må være begrænset til denne zone. Deres forekomst i prøverne under zone I er tolket som nedfald.

Palaeospiroplectammina diversa forekommer i tre eksemplarer fordelt på de to $\varnothing$ verste pr $\varnothing$ ver, $\mathrm{nr} .8$ og 9. »Palaeospiroplectammina mellina optræder i næsten alle prøver under dette niveau, og er her ofte den dominerende form. Bortset fra disse to karakteriseres zone II af slægten Endothyra: E. cf. delepinei i zonens $\varnothing$ vre del, $E$. sp. 1 spredt forekommende i hele zonen, $E$. cf. apposita og E. sp. 2 i zonens midte, medens E. danica, E. spp. (F-29 \& F-44), E. michoti spinata og $E$. aff. prisca karakteriserer zonens nedre del. Med undtagelse af Endothyra sp. 2 er alle Endothyra arterne kun repræsenteret med få eksemplarer i de enkelte prøver. Pr $\varnothing v e$ nr. 29 indeholder dog et større antal af Endothyra danica og E. michoti spinata, samt $\gg$ Palaeospi-

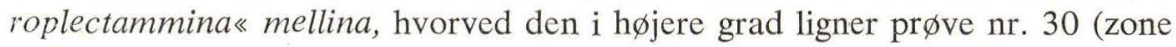
III) end prøverne i zone II. Familien Ozawainellidae, Eostaffella sp. 1, er kun repræsenteret med seks eksemplarer i prøve nr. 28. Endelig forekommer der få eksemplarer af Pseudolituotubella sp. 2 (?) og 3 i prøverne nr. 17 og 28 (?). Endothyra recta, en art der især er karakteristisk i zone IV, kan muligvis forekomme i zone II. Den er meget usikkert bestemt i prøverne nr. 28 og 19. I sidstnævnte prøve er det et eksemplar, der synes at have affinitet til såvel $E$. recta som til $E$. sp. 4.

Zone III: Denne zone omfatter prøverne nr. 30-48 $\left(7695^{\prime}-8180^{\prime}\right)$, der alle er udtaget i den $\emptyset$ vre del af den homogene lagserie med de grå til mørkegrå kalksten og lersten. Prøverne i zone III, især prøverne nr. 30-41, indeholder mange meget velbevarede foraminiferer.

Der synes at være et ret stort artsfællesskab mellem zone II og III, idet næsten alle arter fra zone II er repræsenteret i zone III med et relativt stort antal individer. Zone III's фvre begrænsning er baseret på forekomsten af nye former, som Endothyra spp. (F-37) og E. cf. bradyi, samt den meget kraftige repræsentation af »Palaeospiroplectammina« mellina og Endothyra michoti spinata, der f. eks. i prøve nr. 30 udgør henholdsvis ca. $32 \%$ og ca. $66 \%$ af faunaen. I zone III er der en stor arts- og individ-rigdom, og alle eksemplarer er velbevarede og distinkte. I zone II er faunaen fattig på såvel arter som individer, og skallerne er oftest dårligt bevarede.

Faunaen i zone III er i den øvre del karakteriseret af »Palaeospiroplectammina mellina, Endothyra danica og E. michoti spinata, medens den nedre del domineres og karaktiseres af E. cf. bradyi. Endothyra danica og E. michoti spinata aftager så stærkt uncer prøve nr. 36, at deres forekomst dér 
antagelig skyldes nedfald. Slægten Endothyra præger iøvrigt zone III ved en mere eller mindre spredt forekomst af $E$. sp. 1, E. cf. apposita, E. aff. prisca, E. recta, E. spp. (F-37) og E. sp. 3. Af andre arter skal nævnes Earlandia elegans, Palaeospiroplectammina diversa, Lituotubella glomospiroides minima, Pseudolituotubella sp. 2 og 3, Pseudolit. aff. tenuissima, Septatournayella pseudocamerata, Tetrataxis cf. pusillus, T. sp. 2, Conilites dinantii og Haplophragmina loeblichi. Disse former optræder alle spredt og i få eksemplarer. Denne rigdom på arter findes især i to niveauer: prøve nr. 30, fra en lerstenszone (mergelsten) i kærne nr. 2, og prøverne nr. 36-39. De фvrige afsnit er ikke så artsrige, men indeholder overvejende de ovennævnte, karakteristiske former.

Zone IV: Denne zone omfatter prøverne nr. 49-66 (8180'-8440'), der er udtaget i den nedre del af lagserien, domineret af mørkegrå kalksten. Alle prøverne i denne zone indeholder mange velbevarede foraminiferer. I forhold til antallet af foraminiferer pr. prøve er antallet af arter meget stort. Dette kan måske skyldes nedfald fra zone III. Kun Endothyra danica og E. michoti spinata er aftaget så meget i antal, at deres forekomst i zone IV må skyldes nedfald. De $\emptyset$ vrige former, der er fælles med zone III, optræder så jævnt, at man med god ret kan anse dem for primære.

Zone IV indeholder, udover arter fra zone III, en række arter, der ikke kendes fra de andre zoner. Således betinger den første optræden af Septabrunsiina spissusvoluta den $\emptyset$ vre grænse for zone IV, der iøvrigt karakteriseres af Endothyra recta. Sidstnæunte forekommer spredt i zone III og dominerer i zone IV. Slægten Endothyra er iøvrigt repræsenteret med de samme arter som i zone III, samt $E$. sp. 4, der står meget nær E. recta. Det faunaelement, der adskiller zone IV fra zone III, udgøres af en række arter, der er talmæssigt svagt repræsenteret: Brunsiina pseudopulchra, Septabrunsiina spissusvoluta, Palaeospiroplectammina venusta, $P$. aff. tchernyshinensis, Endothyra sp. 6, Paraendothyra cummingsi, P. nalivkini, Pseudolituotubella sp. 1 og Tetrataxis sp. 1. Palaeosp. venusta forekommer muligvis også i zone III, idet der i prøverne nr. 34 og 38 er fundet et par fragmenter af den biseriale del. Bestemmelsen er imidlertid så usikker, at disse fund ikke kan anvendes her. Palaeospiroplectammina venusta, $P$. aff. tchernyshinensis og Brunsiina pseudopulchra er iøvrigt fundet i zone I (prøve nr. 4).

Af ovenstående gennemgang af faunizonerne I-IV fremgår det, at zone I adskiller sig væsentligt fra de $\varnothing$ vrige tre. Den har en så afvigende fauna, at den kan betragtes som en særskilt stratigrafisk enhed. På grundlag af de faunistiske data må dens $\phi$ vre grænse findes mellem prøve nr. 1 og 2, medens det på grundlag af bjergartssammensætningen vil være naturligt at placere grænsen umiddelbart over prøve nr. 1, ved 6740'. Prøve nr. 1 indeholder så store mængder nedfald fra de overliggende rødlige lersten og sandsten, at der her findes en rimelig forklaring på de manglende fossiler.

Zonerne II, III og IV adskiller sig indbyrdes overvejende ved den til- 
tagende artsrigdom nedefter. Dette synes, sat i relation til sedimenterne, at afspejle miljøet mere end den anvendte boremetode, der giver anledning til nedfald. Arter som »Palaeospiroplectammina« mellina og Palaeospiroplectammina diversa er former, der findes ligeligt fordelt i alle tre zoner. Slægten Endothyra er fremtrædende i hele serien og repræsenteres af former, af hvilke kun få er begrænset til enkelte zoner. En fremtrædende formgruppe, med affinitet til $E$. bradyi, er her repræsenteret af formerne $E$. cf. apposita, $E$. cf. bradyi, E. sp. 1 og E. sp. 2. Med undtagelse af førstnævnte er disse opstillet på grundlag af skallernes ydre morfologi, medens deres indre karakterer peger mod forskellige arter og varieteter som f. eks. E. apposita, E. bradyi obsoleta, E. delepinei, E. volynica, E. phrissa og E. omphalota.

\section{STRATIGRAFISK ANALYSE}

Indledning:

Den unders $\emptyset$ gte lagserie, 6740'-8440' i boringen $\emptyset$ rslev nr. 1, er aflejret i palæozoicum. Den er beliggende under zechstein lag, og en analyse af foraminiferfaunaerne viser, at den skai henf $\varnothing$ res til nedre karbon. Foraminifererne fordeler sig på en række slægter,der har følgende stratigrafiske udbredelse:

Earlandia
Tetrataxis
Brunsiina
Lituotubella
Palaeospiroplectammina
Pseudolituotubella
Septabrunsiina
Septatournayella
Endothyra
Paraendothyra
Haplophragmina

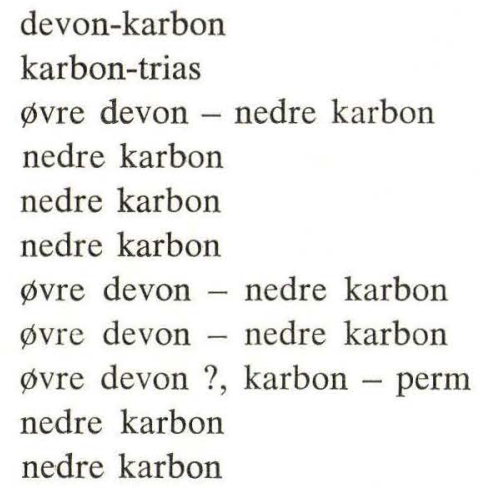

Den kraftige dominans af Endothyra sammenholdt med den hyppige forekomst af Lituotubella, Palaeospiroplectammina og Pseudolituotubella i den største del af lagserien $\left(6945^{\prime}-8440^{\prime}\right)$ viser, at denne skal henføres til nedre karbon. Den $\varnothing$ verste del af lagserien $\left(6740^{\prime}-6945^{\prime}\right)$ domineres af former, der er henført til Ozawainellidae. Denne familie kendes fra karbon og perm. Grundet forekomst af bl. a. slægterne Brunsiina og Palaeospiroplectammina må også dette afsnit henføres til nedre karbon.

Boringen Ørslev nr. 1 er beliggende i den nordlige del af det nedre karbone bassinområde i Nordeuropa. De undersøgte lag og foraminiferfaunaer er nedenfor korreleret til områder, hvorfra relevante foraminiferfaunaer er 
beskrevet: Belgien og Rügen. Korrelation er også foretaget til den russiske del af bassinet, medens de foreliggende oplysninger ikke har tilladt korrelation til den engelske del.

\section{Korrelation til Belgien.}

De nedre karbone aflejringer i Belgien, med typelokaliteterne for de kronostratigrafiske enheder, tournaisien og viséen, er nogle af de bedst beskrevne aflejringer fra neđire karbon i Vesteuropa. Foraminiferfaunaerne er beskrevet detaljeret af ConIL (1963), ConIL \& Lys (1964, 1965, 1966, 1967 og 1968) og FransSEN (1967), hvorfor en korrelation til disse aflejringer er naturlig.

Dominansen af Ozawainellidae i zone I og forekomsten nederst i zone II antyder en tilvækst i denne families andel af faunaen i de undersøgte aflejringer. I de belgiske aflejringer optræder Ozawainellidae første gang nederst i viséen (1a) og er almindelig i viséen 1 b og 2 (CoNIL \& LYs, 1964, 1966 og 1968). Slægten Endothyra, der dominerer i zone II, III og IV og er almindelig i zone I, er repræsenteret med en række former, der kan sammenlignes med arter fra tournaisien $3 \mathrm{og}$ viséen. Endothyra cf. apposita, E. sp. 1, E. sp. 2 og E. cf. bradyi, der er karakteristiske for zone II og III, synes at kunne sammenlignes med tilsvarende arter fra nedre og meliem viséen. E. michoti spinata, zone II og III, står meget nær E. michoti, der kun kendes fra viséen 1 a. E. recta, dominerende i zone IV og forekommende i zone III, er almindelig i viséen 1 a og sjælden i viséen 2b. E. apposita (E. cf. apposita) og E. delepinei ( $E$. cf. delepinei) er begge kendt fra det belgiske $\emptyset$ vre og mellem viséen. Den successive optræden af de ovennævnte Endothyra arter i den undersøgte lagserie synes således at kunne parallelliseres med deres forekomst i det belgiske viséen.

$\gg$ Palaeospiroplectammina mellina, Palaeospiroplectammina diversa, $P$. venusta, Conilites dinantii og slægten Tetrataxis er i de belgiske aflejringer kendt fra tournaisien 3 og viséen 1, samt for enkeltes vedkommende fra viséen 2 og 3. Brunsiina pseudopulchra og B. spirillinoides forekommer i hele viséen, og Paraendothyra cummingsi er begrænset til viséen 1.

Af ovennævnte data fremgår det, at lagserien i boringen $\emptyset$ rslev nr. 1 må sammenlignes med dele af det belgiske viséen. Forekomsten af Endothyra recta, Paraendothyra cummingsi og Palaeospiroplectammina venusta i zone IV sandsynliggør en korrelation til viséen 1, måske viséen 1a. Også zone II og III, med Palaeospiroplectammina diversa og Endothyra michoti spinata, bør antagelig korreleres til viséen 1 ; især den udtalte dominans af sidstnævnte underart i prøve nr. 30 og forekomsten af Ozawainellidae i pr $\varnothing$ ve nr. 28 peger i denne retning. Dominansen af Ozawainellidae i zone I, sammenholdt med bl. a. forekomsten af Endothyra cf. delepinei, kan tyde på, at denne zone ikke skal korreleres med viséen 1, men måske med viséen 2 . 
Hvis ovenstående korrelation er rigtig, mangler der i de undersøgte faunaer et betydningsfuldt element: Archaediscidae. Denne familie er i de belgiske aflejringer meget vigtig i viséen (CONIL \& LYs, 1964 og 1968). Den manglende forekomst af denne familie skyldes antagelig forskelle $\mathrm{i}$ facies, idet de unders $\emptyset$ gte sedimenter må betegnes som overvejende kystnære, paralisk facies.

\section{Korrelation til Rügen.}

Gennem boringer på den tyske $\varnothing$ Rügen er der for få år siden fundet aflejringer af nedre karbon alder. I en foreløbig meddelelse (KNÜPFER \& WEYER, 1967) er der givet en kort karakteristik af sedimenterne og en oversigt over fundne fossiler. Hverken faunaer eller enkelte fossiler er beskrevet. Grundet Rügens geografiske beliggenhed er en sammenligning med disse aflejringer dog vigtig.

Af fællesarter mellem boringen Ørslev nr. 1 og boringerne på Rügen er Endothyra recta på sidstnævnte lokalitet fundet i en lagserie af kalksten og lersten, der på basis af biostratigrafiske data er henført til nederste nedre viséen, og Palaeospiroplectammina diversa i mergelsten og kalksten henført til $\emptyset$ vre viséen. Endelig er Palaeospiroplectammina tchernyshinensis fundet i lersten og mergelsten fra tournaisien, samt i lagene henført til nederste nedre viséen. I sidstnævnte lag er også Endothyra michoti fundet. Forekomsten af Palaeospiroplectammina diversa i lag, der kan henføres til фvre viséen er unormal for denne art, idet den både i U.S.S.R. og Belgien kun kendes fra $\emptyset$ vre tournaisien og nedre viséen. De tre andre arters forekomst på Rügen er derimod i overensstemmelse med deres optræden i boringen $\emptyset$ rslev nr. 1, således som aílejringerne i denne ovenfor er fors $\varnothing$ gt korreleret til de belgiske. En bekræftelse herpå er også at familien Ozawainellidae på Rügen forekommer i de kalksten, der henføres til øverste nedre viséen og mellem viséen, samt lagene henført til $\varnothing$ vre viséen. Endelig skal det nævnes, at familien Archaediscidae kun er fundet i lag henført til $\varnothing v$ re viséen.

Som det ses ovenfor er grundlaget for en korrelation til aflejringerne på Rügen meget svagt. Der er antydninger af lighed mellem zone III og IV og den ca. $400 \mathrm{~m}$ mægtige serie af kalksten med enkelte indslag af lersten, der er henført til 1.ederste nedre viséen. Sedimenterne har samme præg og de to vigtige former Endothyra recta og E. michoti (spinata) forekommer på begge lokałite‘er. Det er dog en meget lille del af faunaerne, der således er fælles. Zone I og II kan måske sammenlignes med den ca. $250 \mathrm{~m}$ mægtige lagserie af massive kalksten, der er henført til фverste nedre viséen og mellem viséen, men også her er faunaernes fællespræg meget lille, idet kun Ozawainellidae's forekomst i disse lag og ikke i de underliggende er fælles. En stærkt sandet serie som i zone II kendes tilsyneladende ikke på Rügen. På grundlag af c̉en nuværende viden om aflejringerne på Rügen må den 
skitserede korrelation være rigtig. Endelige slutninger kan ikke drages f $\varnothing \mathrm{r}$ mere omfattende beskrivelser af faunaerne og sedimenterne publiceres.

\section{Korrelation til U.S.S.R.}

En korrelation til de russiske aflejringer er noget vanskelig grundet den ringe mængde litteratur, der har stået til forfatterens rådighed. Beskrivelser af arter, opstillet i U.S.S.R., er til brug for dette arbejde hentet hos ELLIS \& MEssina (1940 ff.), medens oplysninger om stratigrafisk udbredelse, faunasammensætning $\mathrm{m}$. m. overvejende er hentet fra den vesteuropæiske litteratur. Russisk litteratur tilhørende R. ConIL har dog også været benyttet. Grundet de store faunaligheder mellem de russiske og de belgiske aflejringer er det naturligt at betragte den unders $\varnothing$ gte lagserie som et forbindelsesled med relation til begge sider.

I lighed med udviklingen i de belgiske aflejringer optræder Ozawainellidae og Archaediscidae nederst i viséen, Stalinogorsk horisonten, og udg $\phi \mathrm{r}$ en væsentlig del af faunaen i viséen (ConIL, 1963 og MAMET, 1965). Endothyra recta (zone III og især zone IV) er i U.S.S.R. kun kendt fra aflejringer henført til $\emptyset$ vre tournaisien og nedre viséen, medens $E$. convexa regularis er en vigtig form i mellem viséen. Arter som Earlandia elegans, Brunsiina pseudopulchra, B. spirillinoides, Palaeospiroplectammina diversa, P. venusta, og Septatournayella pseudocamerata er alle kendt fra фvre tournaisien og nedre viséen. »Palaeospiroplectammina mellina kendes kun fra nedre viséen, og Paraendothyra nalivkini fra mellem tournaisien.

En del af de ovennævnte arter, der i U.S.S.R. kendes fra både $\emptyset$ vre tournaisien og nedre viséen, forekommer i de belgiske aflejringer kun i viséen, hvilket antages forårsaget af en afbrydelse af forbindelsen meilem de to bassinområder i dele af фvre tournaisien (ConIL, 1968). Forekomsten af E. convexa regularis i zone I støtter den tidligere nævnte formodning, at denne zone skal korreleres med mellem viséen. Af de $\emptyset$ vrige nævnte arter er det kun Paraendothyra nalivkini, der bringer noget nyt i forhold til korrelationen med Belgien. Denne art er ikke kendt i Vesteuropa og ikke tidligere fundet sammen med Paraendothyra cummingsi. Forekomsten af $P$. nalivkini sammen med Palaeospiroplectammina aff. tchernyshinensis i zone IV kan antyde en mulig korrelation med tournaisien ( $\varnothing$ vre-mellem), men da faunaen i denne zone iøvrigt er en viséenfauna, karakteriseret af Endothyra recta, synes denne mulighed udelukket.

\section{Korrelation til Nordamerika.}

Den biostratigrafiske inddeling af nedre karbon i Nordamerika bygger i høj grad på den fylogenetiske udvikling af endothyroide foraminiferer (J. E. ZELLer, 1950 \& 1957; D. E. N. Zeller, 1953; Woodland, 1958; McKay \& 
Green, 1963). Det har på basis heraf været muligt at give en ret detaljeret zoneinddeling, der dog ikke i alle tilfælde med sikkerhed kan korreleres mellem områderne indbyrdes. Korrelation til de euroasiatiske aflejringer synes især mulig for de vestlige områder i Nordamerika.

Som det ses af ovenstående gennemgang af de fire faunizoner i boringen Ørslev nr. 1 indeholder aflejringerne ingen eller kun svage antydninger af en fylogenetisk udvikling indenfor slægten Endothyra. Former med mange vindinger, mange kamre pr. vinding og tynde tværvolde ( $E$. recta) dominerer nederst, zone IV, og forekommer i zone I, II og III ( $E$. aff. costifera). Zone II og III er præget af former med få vindinger, få kamre pr. vinding og kraftige tværvolde (gruppen $E$. cf. bradyi), samt i grænseområdet mellem de to zoner af den planispirale form $E$. michoti spinata. Zone II og III er yderligere karakteriseret af $E$. danica, der ligner gruppen $E$. cf. bradyi, men mangler interne skalelementer. Zone II og III med gruppen E. cf. bradyi og den planispirale form kan måske sidestilles med aflejringer fra meramecian, bl. a. Salem formationen (E. J. Zeller, 1950). E. michoti spinata har dog så stor lighed med E. tumula, at en korrelation også her kan komme på tale. E. tumula zonen er med nogen usikkerhed henf $\varnothing$ rt til osagian (E. J. ZeLLER, 1957), og endog i enkelte tilfælde regnet for en underzone af Granuliferella zonen (McKay \& Green, 1963). E. cf. delepinei, der forekommer i zone I og II, har meget kraftigt udviklede interne skalelementer, hvormed den har nogen lighed med former fra $\varnothing$ verste meramecian og chesterian. Denne lighed med de nordamerikanske aflejringer fra osagian og meramecian er dog så svag, at den ikke kan danne grundlag for mere entydige slutninger.

\section{Konklusion}

De biostratigrafiske data fra lagserien i boringen $\emptyset$ rslev nr. 1 viser størst overensstemmelse med de belgiske aflejringer. På dette grundlag kan hele lagserien korreleres til dele af viséen (se text-fig. 3). Zone II, III og IV, der alle karakteriseres af Palaeospiroplectammina diversa og slægten Endothyra, skal utvivlsomt korreleres til nedre viséen, viséen 1. Forekomsten af Endothyra recta og Paraendothyra cummingsi i zone IV og Endothyra michoti spinata i zone III kan tydes som en parallel til viséen 1a. Den udprægede dominans af Ozawainellidae, samt forekomsten af Endothyra convexa regularis, i zone I tyder på, at denne er yngre end viséen 1 . Det antages her, at den skal korreleres til mellem viséen (viséen 2).

Da de fleste prøver er taget som skylleprøver, kan man ikke på grundlag af fossiler med sikkerhed fastslå det $\emptyset$ verste niveau for de fossilførende karbone aflejringer i boringen $\emptyset$ rslev nr. 1 . Schlumberger Logs viser en ret ensartet lagserie i afsnittet $6740^{\prime}-6930^{\prime}$. Dette sammenholdt med den beskrevne foraminiferfauna danner grundlag for, at lagserien $6740^{\prime}-8440^{\prime}$ henføres til viséen. 
Grænserne mellem de fire faunizoner kan heller ikke angives med sikkerhed, da alle tre grænseområder er beliggende i skylleborede intervaller. Grænsen mellem zone I og II er lagt mellem en prøve, der er domineret af Ozawainellidae og E. convexa regularis (prøve nr. 7), og en med Palaeospiroplectammina diversa (prøve nr. 8). Dermed lægges grænsen mellem de to zoner ved 6945'. Lagserien $6740^{\prime}-6945^{\prime}$ henf $\phi$ res med nogen usikkerhed til mellem viséen (viséen 2), medens $6945^{\prime}-8440^{\prime}$ skal henføres til nedre viséen (viséen 1 ).

Disse aflejringer bør ses i sammenhæng med de udbredte forekomster af shelfkalksten i Nordeuropa (se BARTenstein, 1968). På overgangen mellem tournaisien og viséen sætter en omfattende transgression ind i det variskiske geosynklinalområde. Med beskrivelsen og den biostratigrafiske analyse af lagserien i boringen Ørslev nr. 1 er det påvist, at denne transgression i det mindste har nået Syddanmark. Sammenlignet med aflejringer på Rügen (KNÜPFER \& WEYER, 1967) har sedimentationsforholdene været mindre stabile i det sydlige Danmark, idet der i perioder er tilført området relativt store mængder groft materiale. Dette skyldes antagelig en mere kystnær beliggenhed.

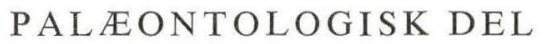

I denne del er foraminifererne beskrevet og anordnet i overensstemmelse med en upubliceret systematik, som R. ConIL venligst har stillet til rådighed. 48 former er beskrevet, heraf er 13 identificeret til art, 9 er med forbehold henført til kendte arter, og 22 er beskrevet med åben nomenklatur. Yderligere er der beskrevet to nye arter: Septabrunsiina spissusvoluta og Endothyra danica, og to nye underarter: Lituotubella glomospiroides minima og Endothyra michoti spinata. Samtlige arter findes afbildet på tavle I-XX og angivet i oversigten på tavle XXII.

Ved undersøgelse af foraminiferfaunaer fra palæozoiske aflejringer er det, bl. a. i Rusland og Belgien, almindeligt at identifikationen af de enkelte individer sker ved tyndslib af den fossilførende bjergart uden at der skaffes noget kendskab til foraminiferskallernes ydre morfologi. I nærværende arbejde er bedømmelsen af de enkelte morfospecies foretaget både på skallernes ydre og indre morfologi; sidstnævnte ved tyndslib af isolerede skaller. Forskellene i valg af metode har i enkelte tilfælde givet vanskeligheder ved identifikation og medvirket til at bl. a. ni former med forbehold er henført til art.

I det unciers $\varnothing$ gte materiale er bevaringstilstanden hos enkelte foraminiferskaller så ringe, at de ikke er indgået i den analyserede del. Det beskrevne materiale er derfor ikke kvantitativt, men skønnes dog at repræsentere faunaernes sammensætning og variation. 


\section{REFERENCES}

Bartenstern, H., 1968. Paläogeographische Probleme beim Aufsuchen von Kohlenwasserstoff-Lagerstätten im Paläozoikum und in der Untertrias von Mittel- und Nordwest-Europa einschliesslich des Nordsee-Raumes. - Erdöl und Kohle etc., Jahrg. 21, nr. 1, - Hamburg.

BraŽnikova, N. E., 1962. Quasiendothyra and related forms from the Lower Carboniferous of the Donetz basin and neighbouring regions of the Ukraine. (In Russian). - Trav. Inst. Sc. Geol., Ac. Sc. RSS Ukraine, ser. strat. paleont., No. 44. Leningrad.

- et al., 1956. La faune et la flore des dépôts du Carbonifère de la dépression gallicovolhynie. - Trav. Inst. Sc. Geol., Ac. Sc. RSS Ukraine, ser. strat. paleont., 10. Leningrad.

Chernysheva, N. E., 1940. On the stratigraphy of the Lower Carboniferous foraminifera in the Makarovski district of the South Ural. (In Russian). - Soc. Nat. Moscow, Bull. n. s., vol. 48 (Sect. geol., vol. 18, No's. 5-6). - Moscow.

- 1948. Some new species of foraminifera from the Visean stage in the Makarovo region, southern Ura1. (In Russian). - Trav. Inst. Sc. Geol., Ac. Sc. URSS., No. 62 (Geol. ser., No. 19). - Moscow.

Christensen, O. Bruun, 1971. Nedre karbon i dybdeboringen Ørslev nr. 1 på Falster. (English Summary: Lower Carboniferous of the Boring Ørslev No. 1 in Falster.) Danmarks Geologiske Undersøgelse, rapp. nr. 6. - København.

ConIL, R., 1963. Interprétion micropaléontologique de quelque sondages de Campine. Bull. Soc. belge Géol. Paléont. Hydrol., vol. LXXII, No. 2. - Bruxelles.

ConIL, R. \& LYS, M., 1964. Materiaux pour l'étude micropaléontologique du Dinantien de la Belgique et de la France. Pt. I \& II. - Mém. Inst. Géol. Univ. Louvain, vol. XXIII. - Louvain.

- 1965. Précisions complémentaires sur la Micropaléontologie du Dinantien. - Annls. Soc. Géol. Belg., vol. 88, Nio. 3. - Liège.

- 1966. Foraminiféres et algues du Tournaisien supérieur et du Viséen de la Belgique. - Annls. Soc. Géol. Belg., vol. 89, No. 6. - Liège.

- 1967. Apercu sur les associations de foraminifères endothyroides du Dinantien de laBelgique. - Annls. Soc. Géol. Belg. vol 90, No. 4. - Liège.

- 1968. Utilisation stratigraphique des foraminifères du Dinantien. - Annls. Soc. Géol. Belg., vol. 91. - Liège.

Conil, R., Austin, R. L., Lys, M. \& Rhodes, F. H. T., 1969. La limite des étages tournaisien et viséen au stratotype de l'assisse de Dinant. - Bull. Soc. Belge Géol. Paléont. Hydrol., vol. LXXVII, No. 1. - Bruxelles.

Cummings, R. H., 1955. New genera of foraminifera from the British Lower Carboniferous. - Wash. Akad. Sci., Journ., vol. 45, No. 1. - Baltimore.

- 1955. Nodosinella BRADY, 1876, and associated Upper Palaeozoic genera. - Micropaleontology, vol. 1, No. 3. - New York. 
- 1956. Revision of the Upper Palaeozoic textulariid foraminifera. - Micropaleontology, vol. 2, No. 3. - New York.

-- 1958. The faunal analysis and stratigraphical application of Upper Palaeozoic foraminifera. - Micropaleontology, vol. 4, No. 1. - New York.

- 1961. The Foraminiferal Zones of the Carboniferous Sequence of the Archerbeck Borehole, Canonbie, Dumfrieshire. - Bull. geol. Surv. Gr. Br., No. 18. - London.

DaIN, L. G. \& Grozdilova, L. P., 1953. Fossil Foraminifera of the USSR: Tournayellidae and Archaediscidae. (In Russian). - Trudy, vses. neft. nauchno-issled. geol.-razv. Inst., No. 75. - Leningrad.

Dvoř́́k, J. \& ConIL, R., 1969. Foraminifères du Dinantien de Moravie. - Bull. Soc. Belge Géol. Paléont. Hydrol., vol. LXXVII, No. 1. - Bruxelles.

Ehrenberg, C. G., 1854. Mikrogeologie. - L. Voss. - Leipzig.

EıскноғF, G., 1968. Neue Textularien (Foraminifera) aus dem Waldecker Unterkarbon. - Paläont. Z., 42, 3/4. - Stuttgart.

Ellis, B. F. \& Messina, A. R., 1940 ff. Catalogue of Foraminifera. - Am. Mus. Nat. Hist., Spec. Publ. - New York.

Franssen, L., 1967. Données nouvelles sur les foraminifères du Tournaisien et du Viséen. - Annls. Soc. Géol. Belg., vol. 90, No. 6. - Liège.

Ganelina, R. A., 1956. Foraminifera of the Visean of the northwestern regions of the sub-Moscow Basin. (In Russian). - Trudy vses. neft. nauchno-issled. geol.-razv. Inst. Microfauna SSSR, n. s., No. 8. - Leningrad.

GiRTY, G. H., 1915. The fauna of the Batesville sandstone of northern Arkansas. Bull. U. S. Geol. Surv., No. 593. - Washington.

Grozdilova, L. P. \& Glebovskaia, E. M., 1948. In: Rauser-Černoussova, D. M. et al. Stratigraphy and foraminifera of the Lower Carboniferous of the Russian Platform and the Cis-Ural region. (In Russian). - Trav. Inst. Sc. Géol., Ac. Sc. URSS, No. 62 (Geol. ser. No. 19). - Moscow.

Grozdilova, L. P. \& Lebedeva, N. S., 1954. Foraminifera from the Lower Carboniferous and the Middle Carboniferous, Bashkirian, of the Kolva-Vishera region. (In Russian). - Trudy vses, neft. nauchno-issled. geol.-razw. inst., Microfauna SSSR, n. s., No. 7. - Leningrad.

KNÜPFER, J. \& WeYER, D., 1967. Vorfäufige Mitteilung über das Unterkarbon der Insel Rügen. - Ber. dt. Ges. Geol. Wiss., Geol. Paläont., A., 3/4, 12. Band. - Berlin.

Lebedeva, N. S., 1954. Foraminifera from the Lower Carboniferous of the Kuznetsk Basin. (In Russian). - Trudy vses. neft. nauchno-issled. geol.-razv. Inst., Microfauna SSSR, n. s., No. 7. - Leningrad.

Lipina, O. A., 1948. In: RAuser-Černoussova, D. M. et al. Stratigraphy and foraminifera of the Lower Carboniferous of the Russian Platform and the Cis-Ural region. (In Russian). - Trav. Inst. Sc. Geol., Ac. Sc. URSS, No. 62 (Geol. ser., No. 19). Moscow.

- 1953. In: Dain, L. G. \& Grozdilova, L. P., 1953 (see above).

- 1955. Foraminifera of the Tournaisian and Upper Devonian of the Volga-Ural region and the western slopes of the Middle Urals. (In Russian). - Trav. Inst. Geol. Ac. Sc. URSS, No. 163 (Geol. ser., No. 70). - Moscow.

- 1965. Systematics of the Tournayellidae. (In Russian). - Akad. Sc. USSR, Inst. Geol. Nauka, No. 130. - Moscow.

- 1970. Evolution of Biserial Rectilinear Foraminifera of the Early Carboniferous. (In Russian). - Akad. Nauk SSSR. Ordena Trudovogo Krasnogo Znamenij Geologiceskii Institut. Voprosji Mikropaleontologii. 13.

Malakhova, N. P., 1956. Les Foraminifères provenant des calcaires de la rivière 
Sartymka dans L'Oural méridional. (In Russian). - Trav. Inst. Geol. Minier, Ac. Sc. URSS, No. 24, ser. Strat., No. 3. - Leningrad.

McKay, W. \& Green, R., 1963. Mississippian foraminifera of the southern Canadian Rocky Mountains, Alberta. - Council Alberta, Bull. 10 - Alberta.

Mikhailov, A. V., 1939. In: Mikhailov, A. V. (ed.). The Lower Carboniferous deposits of the northwestern slope of the Moscow Basin. (In Russian). - Leningrad, Geol. Admin., Symposium, No. 3. - Leningrad.

Plummer, H. J., 1930. Calcareous Foraminifera in the Brownwood Shale near Bridgeport, Texas. - Univ. Texas, Bull. No. 3019. - Texas.

Rauser-Černoussova, D. M., 1937. In: Rauser-Černoussova, D. M. \& Fursenko, A. V. Guide to the foraminifera of the oil-bearing regions of the USSR; Part I. (In Russian). - Unit. Scient. Tech. Press (ONTI). - Leningrad and Moscow.

- 1948. Contributions to the foraminiferal fauna of the Carboniferous deposits of central Kazakhstan. (In Russian). - Trav. Inst. Sc. Geol., Ac. Sc. URSS, No. 66 (Geol. ser., No. 21). - Moscow.

- 1948. In: RAuSER-ČERnoussova, D. M. et al. Stratigraphy and foraminifera of the Lower Carboniferous of the Russian Platform and the Cis-Ural region. (In Russian). - Trav. Inst. Sc. Geol., Ac. Sc. URSS, No. 62 (Geol. ser., No. 19). - Moscow.

Rauser-Černoussova, D. M., Beljaev, G. M. \& Reitlinger, E. A., 1936. Die oberpalaeozoischen Foraminiferen aus dem Petschora-Lande (der Westabhang des NordUrals). (In Russian with German summary). - Trav. Comm. Polar, Ac. Sc. URSS, No. 28. - Leningrad.

Reitlinger, E. A., 1950. Foraminifera of the Middle Carboniferous deposits of the central part of the Russian Platform (exclusive of the family Fusulinidae). (In Ru'ssian). - Trav. Inst. Sc. Geol., Ac. Sc. URSS, No. 126 (Geol. ser., No. 47). Moscow.

Rozovskaya, S. E., 1961. On the systematics of the families Endothyridae and Ozawainellidae. - Paleont. Zh., Ac. Sc. URSS, No. 3. - Moscow.

Said, R. \& Barakat, M. G., 1958. Jurassic microfossils from Gebel Maghara, Sinai, Egypt. - Micropaleontology, vol. 4, No. 3. - New York.

VDovenko, M. V., 1954. Quelques nouvelles espèces de Foraminifères des dépôts du Viséen inférieur du Bassin du Donetz. (In Russian). - Notes Sc. Univ. Ševčenko Kiev, vol. 13, No. 4.

- 1967. Quelques représentants Endothyridae, Tournayellidae et Lituolidae des dépôts du Viséen inférieur du grand Donbass. (In Russian). - Akad. Sc. Ukraine CCP, Inst. geol. Nauk.

- 1970. New findings about the Systematics of the Family Forschiidae. (In Russian). Geol. Journ., vol. XXX, No. 3. - Kiev.

WoOdland, R., 1958. Stratigraphic significance of Mississippian endothyroid fauna in central Utah. - Journ. Pal., vol. 32, No. 5. - Oklahoma.

Zeller, E. J., 1950. Stratigraphic significance of Mississippian endothyroid Foraminifera. - Paleont. Contr. Univ. Kansas, Protozoa, art. 4. - Kansas.

- 1957. Mississippian endothyroid foraminifera from the Cordilleran geosyncline. Journ. Pal., vol. 31, No. 4. - Oklahoma.

ZELLER, D. E. N., 1953. Endothyroid foraminifera and ancestral fusulinids from the type Chesteran (Upper Mississippian). - Journ. Paul., vol. 27, No. 2. - Oklahoma. 
PLATES 


\section{PLATE I}

$60 \times$

D.G.U. Text Catalogue No. page

Fig. 1. Earlandia elegans (RAUs.-ČERN. \& REITL. 1937) . ... 1970-OM- $1 \quad 32$

Depth 7920'-7930'.

Length: $0.61 \mathrm{~mm}$, diameter of proloculum: $0.12 \mathrm{~mm}$.

Fig. 2. ? Earlandia elegans (RAUS.-ČERN. \& REITL. 1937) ... . 1970-OM- 2 32

Depth 7920'-7930'.

Fig. 3. Lugtonia ? sp.

$1970-O M-3$

Depth 7920'-7930'.

Length: $0.32 \mathrm{~mm}$, breadth: $0.15 \mathrm{~mm}$.

Fig. 4. Palaeotextularia sp.

1970-OM- 4 34

Depth $8320^{\prime}-8323^{\prime}$.

Length: $0.63 \mathrm{~mm}$, breadth: $0.25 \mathrm{~mm}$.

Fig. 5. Tetrataxis ef. pressulus MaLakHova 1956

1970-OM- 5 34

Depth 6930'-6940'.

Diameter: $0.52 \mathrm{~mm}$, height: $0.19 \mathrm{~mm}$.

Figs. 6-7. Tetrataxis cf. pusillus CONIL \& Lys 1964

Fig. 6: Depth $7700^{\prime} 0^{\prime \prime}-5$

$1970-O M-6$

Diameter: $0.42 \mathrm{~mm}$, height: $0.25 \mathrm{~mm}$.

Fig. 7: Depth 7712'7"-7713' . . . . .

1970-OM- 7

Diameter: $0.38 \mathrm{~mm}$, height: $0.19 \mathrm{~mm}$.

Fig. 8. Tetrataxis sp. 1

1970-OM- 8 35

Depth 8386'-8390'.

Diameter: $0.33 \mathrm{~mm}$, height: 0.10 ? $\mathrm{mm}$.

Fig. 9. Tetrataxis sp. 2

1970-OM- 9 35

Depth $7712^{\prime} 7^{\prime \prime}-7713^{\prime}$.

Diameter: $0.33 \mathrm{~mm}$, height: $0.09 \mathrm{~mm}$.

Figs. 10-13. Brunsiina pseudopulchra (LIPINA 1955)

Fig. 10: Depth $8240^{\prime}-8250^{\prime} \ldots \ldots \ldots \ldots \ldots \ldots \ldots \ldots$

Diameter: $0.42 \mathrm{~mm}$.

Fig. 11: Depth $8240^{\prime}-8250^{\prime} \ldots \ldots \ldots \ldots \ldots \ldots \ldots \ldots$

Diameter: $0.44 \mathrm{~mm}$, breadth: $0.11 \mathrm{~mm}$.

Fig. 12: Depth $8280^{\prime}-8290^{\prime}$

Diameter: $0.52 \mathrm{~mm}$, breadth: $0.12 \mathrm{~mm}$.

Fig. 13: Depth $8290^{\prime}-8300^{\prime}$

1970-OM-10

Diameter: $0.44 \mathrm{~mm}$.

1970-OM-11

1970-OM-12

1970-OM-13

Phot. O. Neergaard Rasmussen. 
Plate I

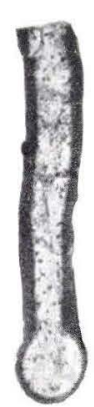

1

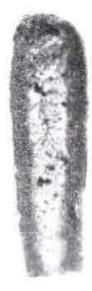

2

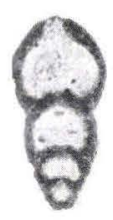

3

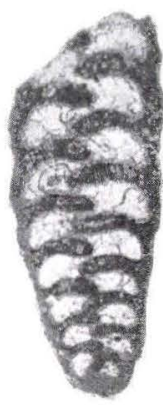

4

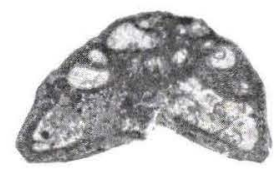

6
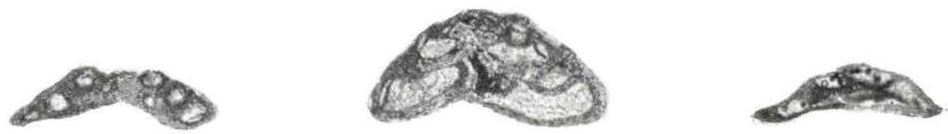

8

7

9
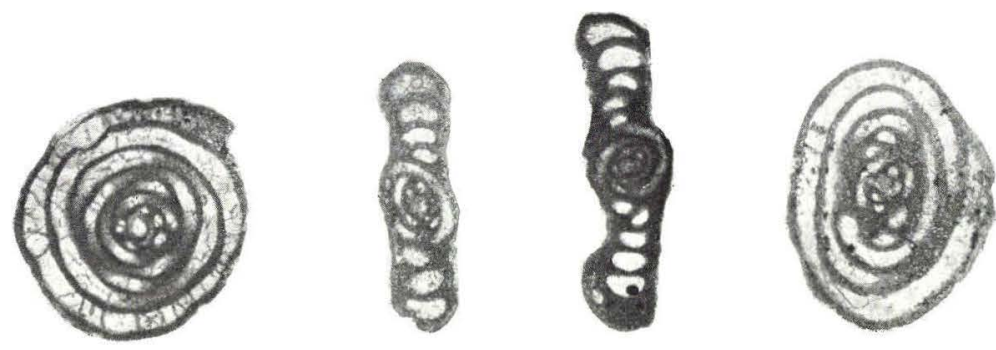

10

11

12

13 


\section{PLATE II}

$60 \times$

Figs. 1-3. Brunsiina pseudopulchra (LIPINA 1955)

D.G.U. Text

Catalogue No. page

Fig. 1: Depth $8290^{\prime}-8300^{\prime}$

Diameter: $0.28 \mathrm{~mm}$.

Fig. 2: Depth $8290^{\prime}-8300^{\prime}$

1970-OM-14

Diameter: $0.28 \mathrm{~mm}$, breadth: $0.08 \mathrm{~mm}$.

Fig. 3: Depth $8190^{\prime}-8200^{\prime} \ldots \ldots \ldots$. . .

1970-OM-15

Diameter: 0.36 ? $\mathrm{mm}$, breadth: $0.09 \mathrm{~mm}$.

Figs. 4-6. Brunsiina spirillinoides (GrozD. \& GLEB. 1948)

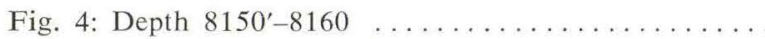

Diameter: $0.60 \mathrm{~mm}$, breadth: $0.14 \mathrm{~mm}$.

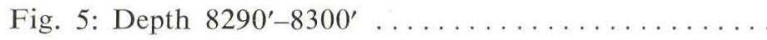

Diameter: $0.58 \mathrm{~mm}$, breadth: $0.14 \mathrm{~mm}$.

Fig. 6: Depth $8420^{\prime}-8430^{\prime} \ldots \ldots \ldots \ldots \ldots \ldots$ 1970-O . . . . . . . 19

Diameter: $0.56 \mathrm{~mm}$, breadth: $0.10 \mathrm{~mm}$.

Figs. 7-11. "Palaeospiroplectammina" mellina (MalakHova 1965)

42

Fig. 7: Depth 7700' 0"-5"

1970-OM-20

Length: $0.50 \mathrm{~mm}$, breadth: $0.26 \mathrm{~mm}$.

Fig. 8: Depth $7830^{\prime}-7840^{\prime}$

1970-OM-21

Length: $0.28 \mathrm{~mm}$.

Fig. 9: Depth 7830'-7840'

1970-OM-22

Length: $0.29 \mathrm{~mm}$.

Fig. 10: Depth $7408^{\prime}-7420^{\prime} \ldots \ldots \ldots \ldots \ldots \ldots \ldots \ldots$

1970-OM-23

Length: $0.38 \mathrm{~mm}$, breadth: $0.22 \mathrm{~mm}$.

Fig. 11: Depth 8440'

1970-OM-24

Length: $0.40 \mathrm{~mm}$, breadth: $0.17 \mathrm{~mm}$.

Fig. 12. "Palaeospiroplectammina" sp.

1970-OM-25

Depth 7700' 0"-5".

Length: $0.65 \mathrm{~mm}$.

Figs. 13-15. Palaeospiroplectammina venusta (VDOVENKo 1954)

Fig. 13: Depth $8290^{\prime}-8300^{\prime}$

1970-OM-26

Length: $0.41 \mathrm{~mm}$, breadth: $0.19 \mathrm{~mm}$.

Fig. 14: Depth $8240^{\prime}-8250^{\prime} \ldots \ldots \ldots \ldots \ldots \ldots \ldots \ldots$

Length: $0.58 \mathrm{~mm}$, breadth: $0.24 \mathrm{~mm}$.

1970-OM-27

Fig. 15: Depth $8260^{\prime}-8270^{\prime} \ldots \ldots \ldots \ldots \ldots \ldots \ldots \ldots$

Length: $0.46 \mathrm{~mm}$, breadth: $0.21 \mathrm{~mm}$.

1970-OM-28

Phot.: O. Neergatrd Rasmussen (figs. 1, 2, 4-9 \& 11-15) and the author (figs. 3 \& 10). 
Plate II
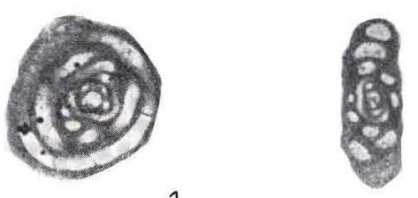

1

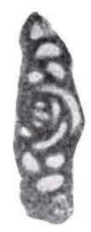

3
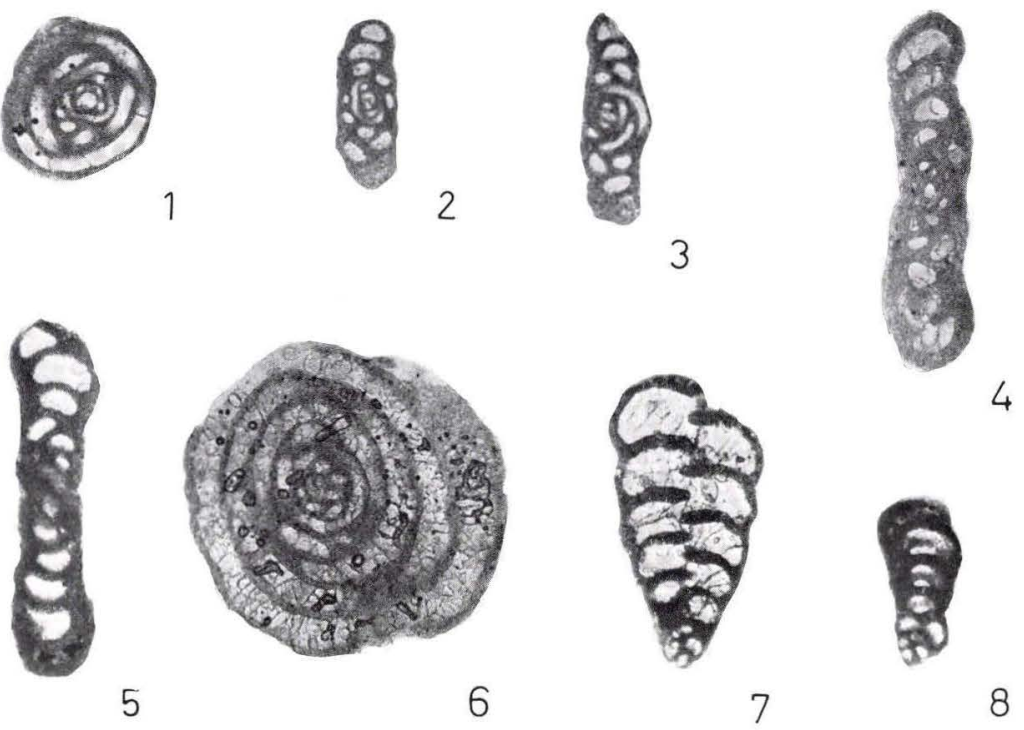

5

6

7
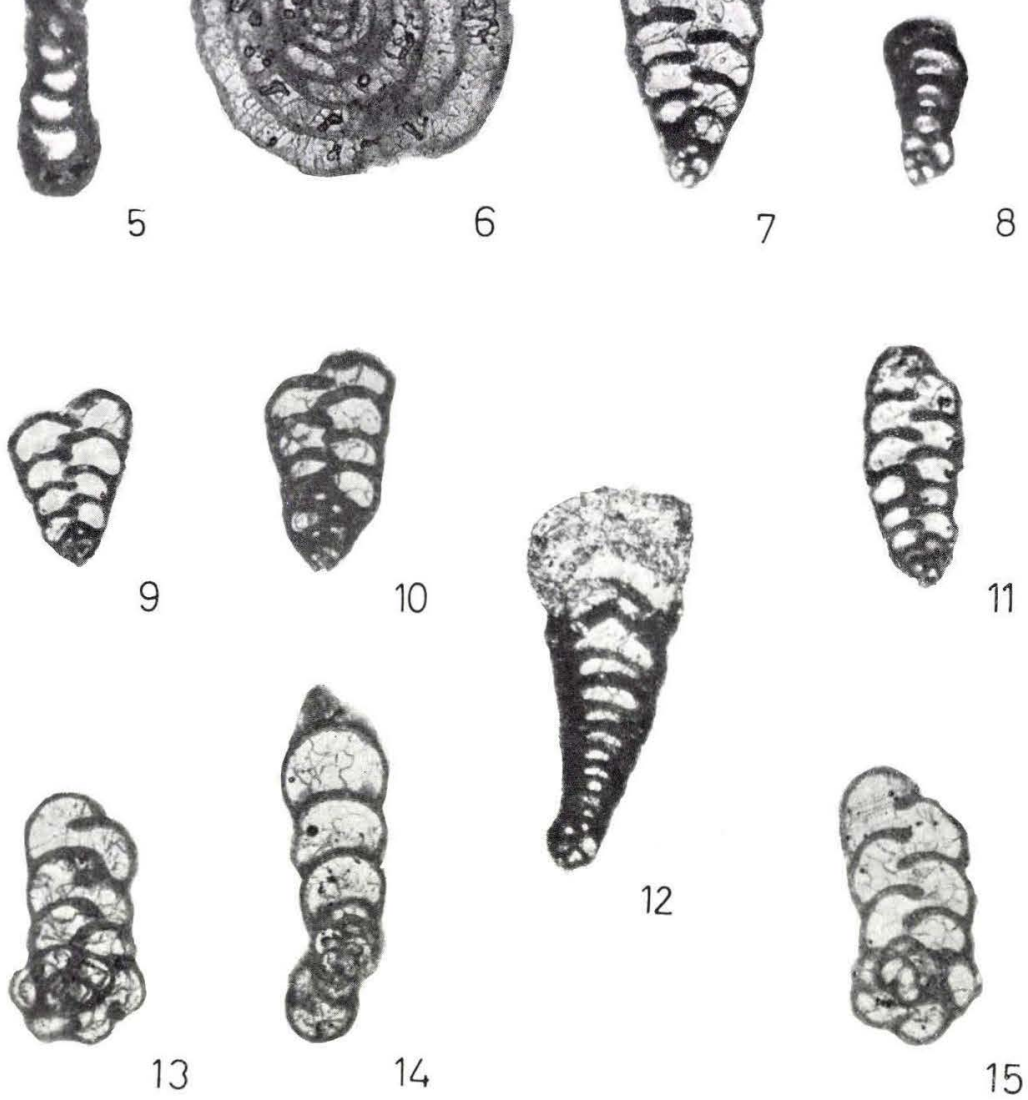

15 


\section{PLATE III}

$60 \times$

D.G.U. Text

Catalogue No. page

Figs. 1-2. Palaeospiroplectammina aff. tchernyshinensis (LiPINA 1948)

Fig. 1: Depth $8240^{\prime}-8250^{\prime}$

1970-OM-29

Length: $0.45 \mathrm{~mm}$, breadth: $0.17 \mathrm{~mm}$.

Fig. 2: Depth $8400^{\prime}-8410^{\prime} \ldots \ldots \ldots \ldots \ldots \ldots \ldots$. . . . . . . . . . .

Length: $0.37 \mathrm{~mm}$, breadth: $0.18 \mathrm{~mm}$.

Fig. 3. Palaeospiroplectammina sp.

1970-OM-31

Depth $8230^{\prime}-8240^{\prime}$.

Length: $0.43 \mathrm{~mm}$, breadth: $0.19 \mathrm{~mm}$.

Figs. 4-7. Palaeospiroplectammina diversa (CHERN. 1948)

Fig. 4: Depth 7930'-7940'

1970-OM-32

Length: $1.05 \mathrm{~mm}$, breadth: $0.65 \mathrm{~mm}$.

Fig. 5: Depth $7930^{\prime}-7940^{\prime} \ldots \ldots \ldots \ldots$

Length: $0.91 \mathrm{~mm}$, breadth: $0.71 \mathrm{~mm}$.

Fig. 6: Depth $7900^{\prime}-7910^{\prime}$

1970-OM-34

Length: $0.54 \mathrm{~mm}$, breadth: $0.53 \mathrm{~mm}$.

Fig. 7: Depth 7930' $7940^{\prime}$

1970-OM-35

Length: $0.62 \mathrm{~mm}$, breadth: $0.56 \mathrm{~mm}$.

Fig. 8. Indet. gen. sp. (F-75)

1970-OM-36

Depth 8280 '-8290'

Length: $1.14 \mathrm{~mm}$, breadth: $0.34 \mathrm{~mm}$.

Phot. O. Neergatrd Rasmussen (figs. 1, 3, 4, 6-8) and the author (figs. 2 \& 5). 
Plate III

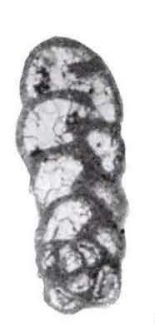

1
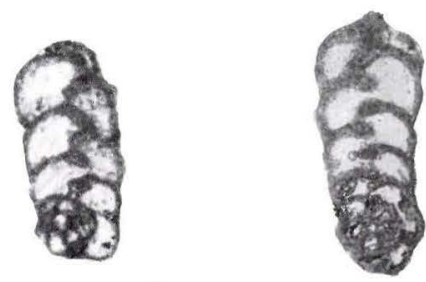

2
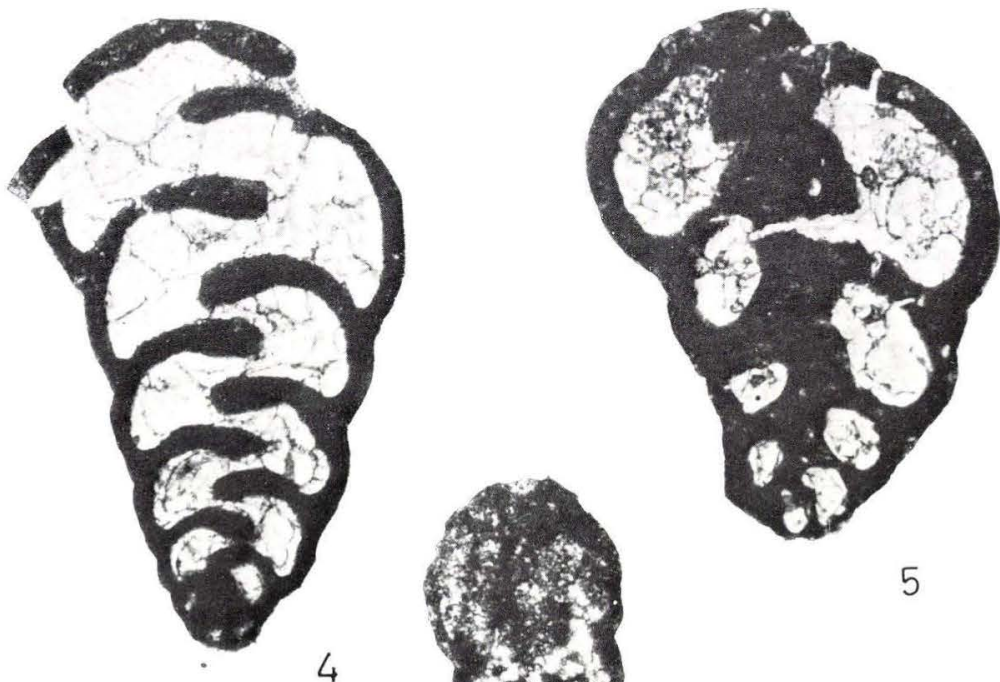

5

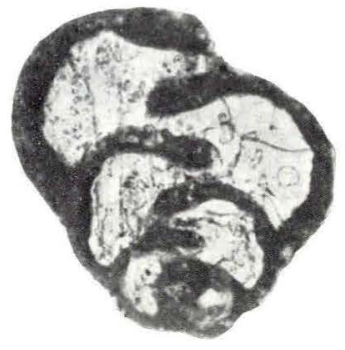

6
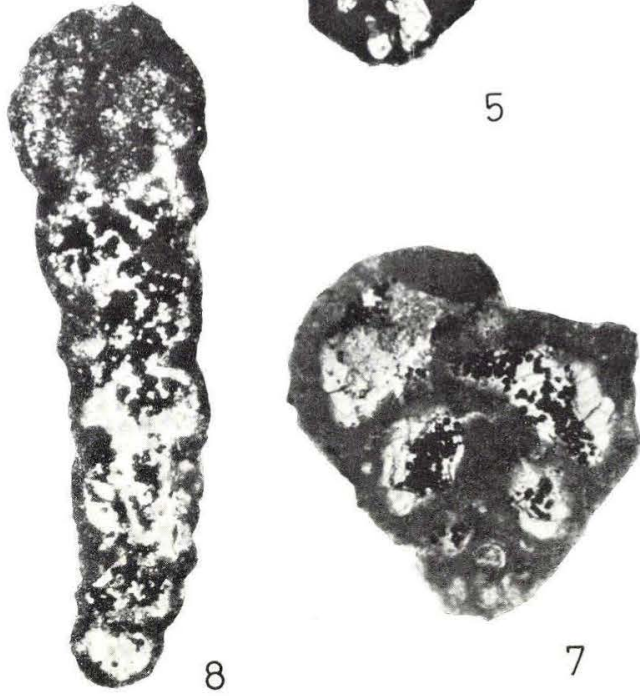


\section{PLATE IV}

$60 \times$

Figs. 1-2. Pseudolituotubella sp. 2

Fig. 1: Depth 8290'-8300'

Length: $0.76 \mathrm{~mm}$, diameter: $0.48 \mathrm{~mm}$.

Fig. 2: Depth 7700' $0^{\prime \prime}-5^{\prime \prime}$

Length: $0.67 \mathrm{~mm}$, diameter $0.55 \mathrm{~mm}$.

Figs. 3-7. Lituotubella glomospiroides minima n. subsp.

Fig. 3: Depth 7920'-7930'

Length: $0.81 \mathrm{~mm}$, diameter: $0.60 \mathrm{~mm}$.

Fig. 4: Depth 7700' $0^{\prime \prime}-5^{\prime \prime}$

Length: $0.71 \mathrm{~mm}$, diameter: $0.49 \mathrm{~mm}$.

Fig. 5: Depth 7700' $0^{\prime \prime}-5^{\prime \prime}$

Diameter: $0.57 \mathrm{~mm}$.

Fig. 6: Depth 7700' $0^{\prime \prime}-5^{\prime \prime}$.

Diameter: $0.49 \mathrm{~mm}$.

Fig. 7: HOLOTYPE. Depth 7700' 0"-5"

Length: $1.77 \mathrm{~mm}$, diameter: $0.55 \mathrm{~mm}$.

Phot. O. Neergaard Rasmussen.
D.G.U. Text Catalogue No. page

1970-OM-37

1970-OM-38

39

1970-OM-39

1970-OM-40

1970-OM-41

1970-OM-42

1970-OM-43 

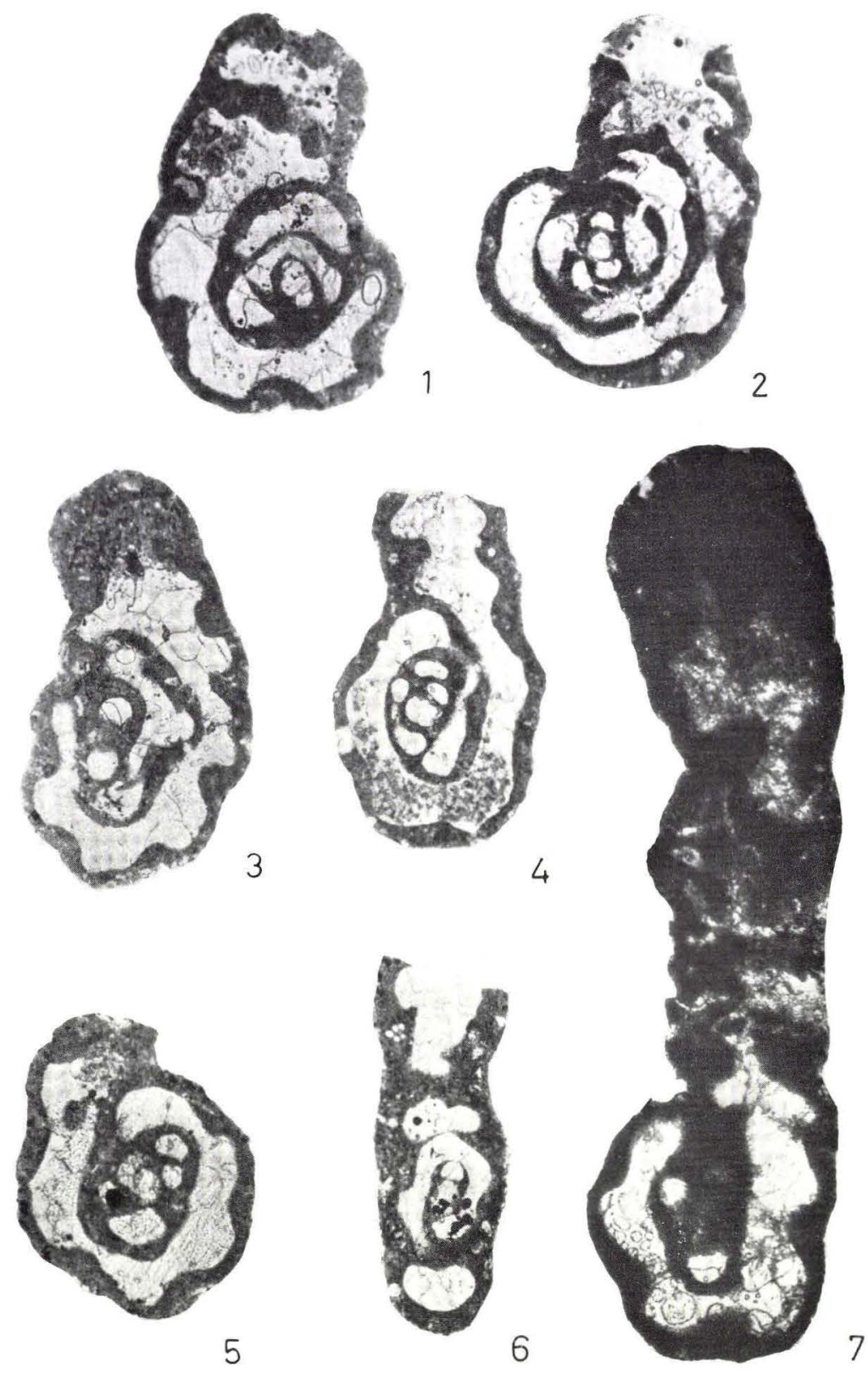
PLATE V

$60 \times$

Figs. 1-3. Pseudolituotubella aff. tenuissima (VDovenko 1954)

Fig. 1: Depth $8280^{\prime}-8290^{\prime}$

Length: $0.86 \mathrm{~mm}$, diameter: $0.62 \mathrm{~mm}$.

Fig. 2: Depth $8260^{\prime}-8270^{\prime}$

Length: $0.80 \mathrm{~mm}$, diameter: $0.51 \mathrm{~mm}$.

Fig. 3: Depth $8260^{\prime}-8270^{\prime}$

Length: $0.66 \mathrm{~mm}$, diameter: $0.53 \mathrm{~mm}$.

Figs. 4-5. Pseudolituotubella sp. 3

Fig. 4: Depth $8370^{\prime}-8380^{\prime}$

Length: $1.44 \mathrm{~mm}$, diameter: $0.60 \mathrm{~mm}$.

Fig. 5: Depth $8290^{\prime}-8300^{\prime}$

Length: $0.88 \mathrm{~mm}$, diameter: $0.60 \mathrm{~mm}$.

Fig. 6. Pseudolituotubella sp. 3 (?)

Depth $7700^{\prime} 0^{\prime \prime}-5^{\prime \prime}$.

Fig. 7. Pseudolituotubella sp. 1

1970-OM-50

D.G.U. Text Catalogue No. page

47

1970-OM-44

1970-OM-45

1970-OM-46

49

1970-OM-47

1970-OM-48

1970-OM-49

Depth 8290'-8300'

Length: $0.74 \mathrm{~mm}$, diameter: $0.50 \mathrm{~mm}$.

Phot. O. Neergaard Rasmussen. 
Plate V

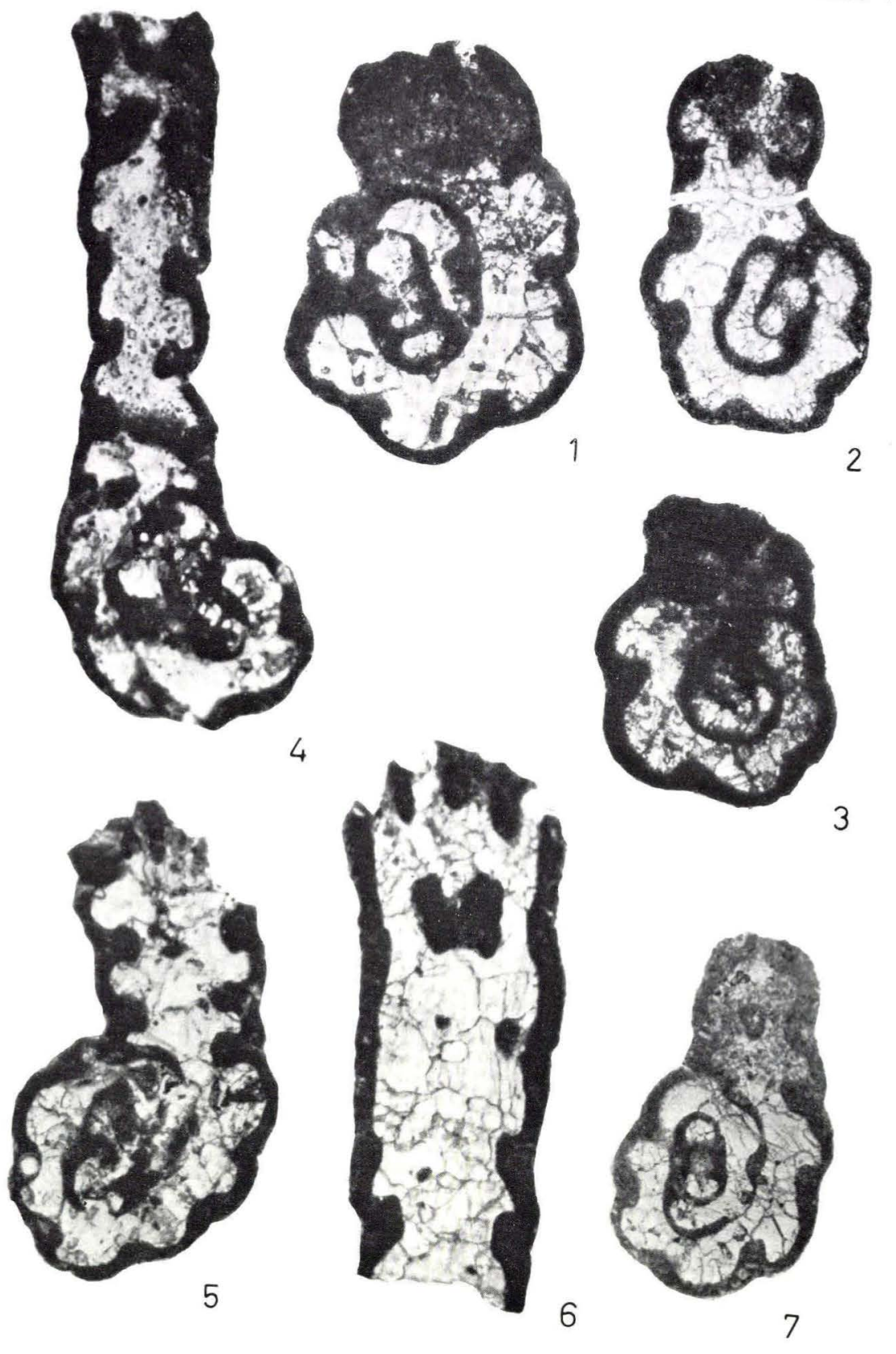


PLATE VI

$60 \times$

Figs. 1-3. Conilites dinantii (CONIL \& Lys 1964)

Fig. 1: Depth 7920'-7930'

Diameter: $0.95 \mathrm{~mm}$.

Fig. 2: Depth 7930'-7940'

Diameter: $0.89 \mathrm{~mm}$.

Fig. 3: Depth $8119^{\prime}-8130^{\prime}$

Length: $1.25 \mathrm{~mm}$, diameter: $0.89 \mathrm{~mm}$.

Figs. 4-7. Septabrunsiina spissusvoluta n. sp.

Fig. 4: Depth 8290'-8300'

Diameter: $0.32 \mathrm{~mm}$, breadth: $0.11 \mathrm{~mm}$.

Fig. 5: Depth $8190^{\prime}-8200^{\prime}$

Diameter: $0.39 \mathrm{~mm}$, breadth: $0.10 \mathrm{~mm}$.

Fig. 6: Depth $8350^{\prime}-8360^{\prime} \ldots \ldots \ldots \ldots$
Diameter: $0.48 \mathrm{~mm}$, breadth: $0.12 \mathrm{~mm}$.

Fig. 7: HOLOTYPE. Depth $8280^{\prime}-8290^{\prime}$

Diameter: $0.48 \mathrm{~mm}$.
D.G.U. Text Catalogue No. page

1970-OM-51

1970-OM-52

1970-OM-53

50

Phot. O. Neergaard Rasmussen. 

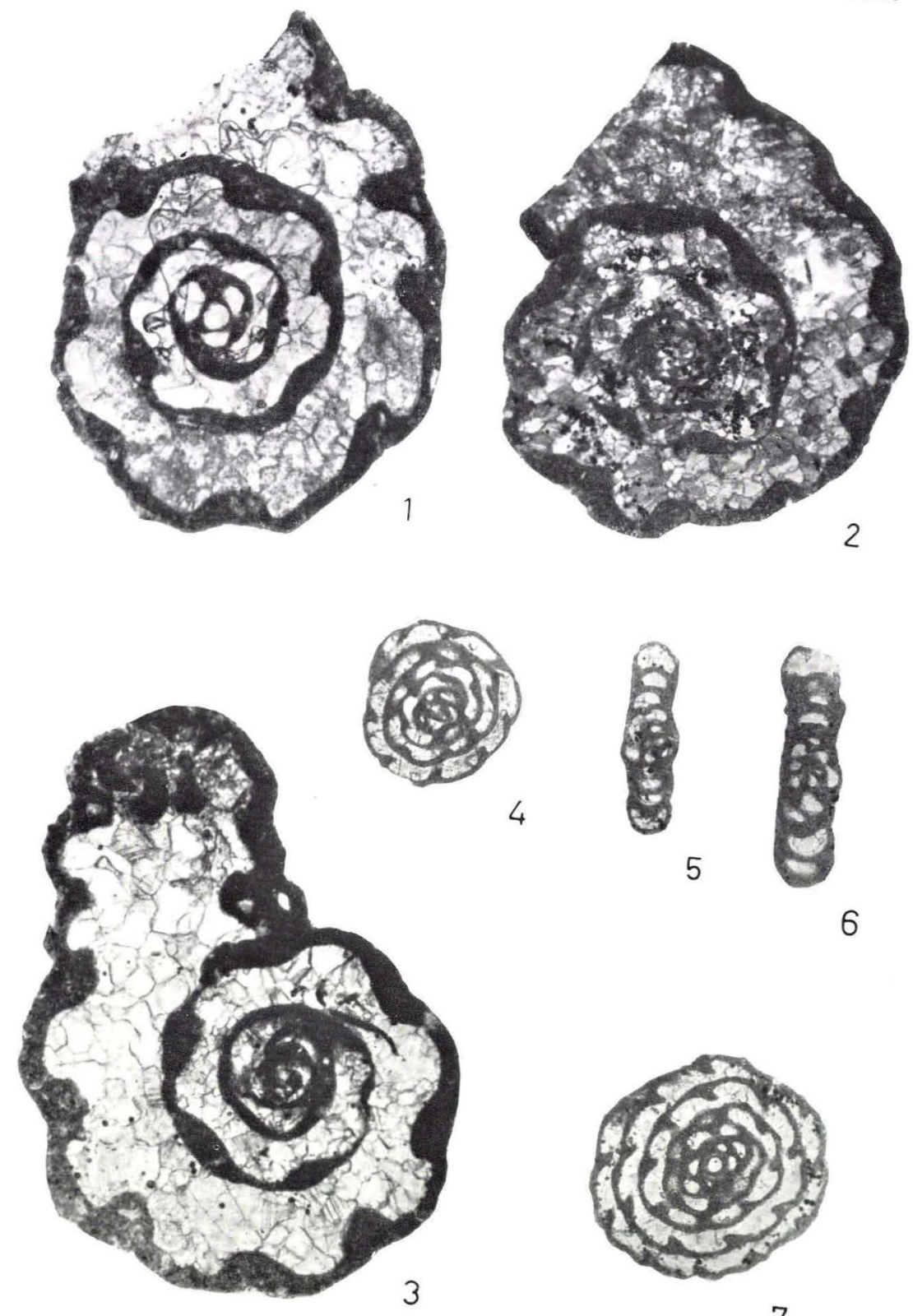

6

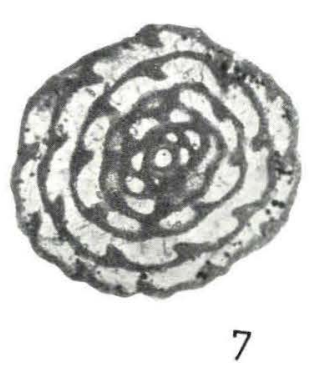




\section{PLATE VII}

$60 \times$

D.G.U. Text Catalogue No. page

Fig. 1. Septatournayella pseudocamerata LeBEDEVA 1954 ... 1970-OM-58

Depth 7700' 0"-5".

Diameter: $0.96 \mathrm{~mm}$, breadth: $0.46 \mathrm{~mm}$.

Figs. 2-3. Endothyra cf. apposita GANELINA 1956

Fig. 2: Depth 7880'-7890'

Diameter: $0.79 \mathrm{~mm}$.

Fig. 3: Depth 7160'-7170'

1970-OM-59

Diameter: $0.56 \mathrm{~mm}$.

Figs. 4-8. Endothyra cf. bradyi Mikhailov 1939

Fig. 4: Depth $7830^{\prime}-7840^{\prime \prime}$

1970-OM-61

Diameter: $0.60 \mathrm{~mm}$.

Fig. 5: Depth 7830'-7840'

1970-OM-62

Diameter: $0.61 \mathrm{~mm}$, breadth: $0.28 \mathrm{~mm}$.

Fig. 6: Depth 7880'-7890'

1970-OM-63

Diameter: $0.63 \mathrm{~mm}$.

Fig. 7: Depth 7880'-7890'

1970-OM-64

Diameter: $0.49 \mathrm{~mm}$.

Fig. 8: Depth $7830^{\prime}-7840^{\circ}$

1970-OM-65

Diameter: $0.58 \mathrm{~mm}$.

Phot. O. Neergatrd Rasmussen (figs. 2-8) and the author (fig. 1). 

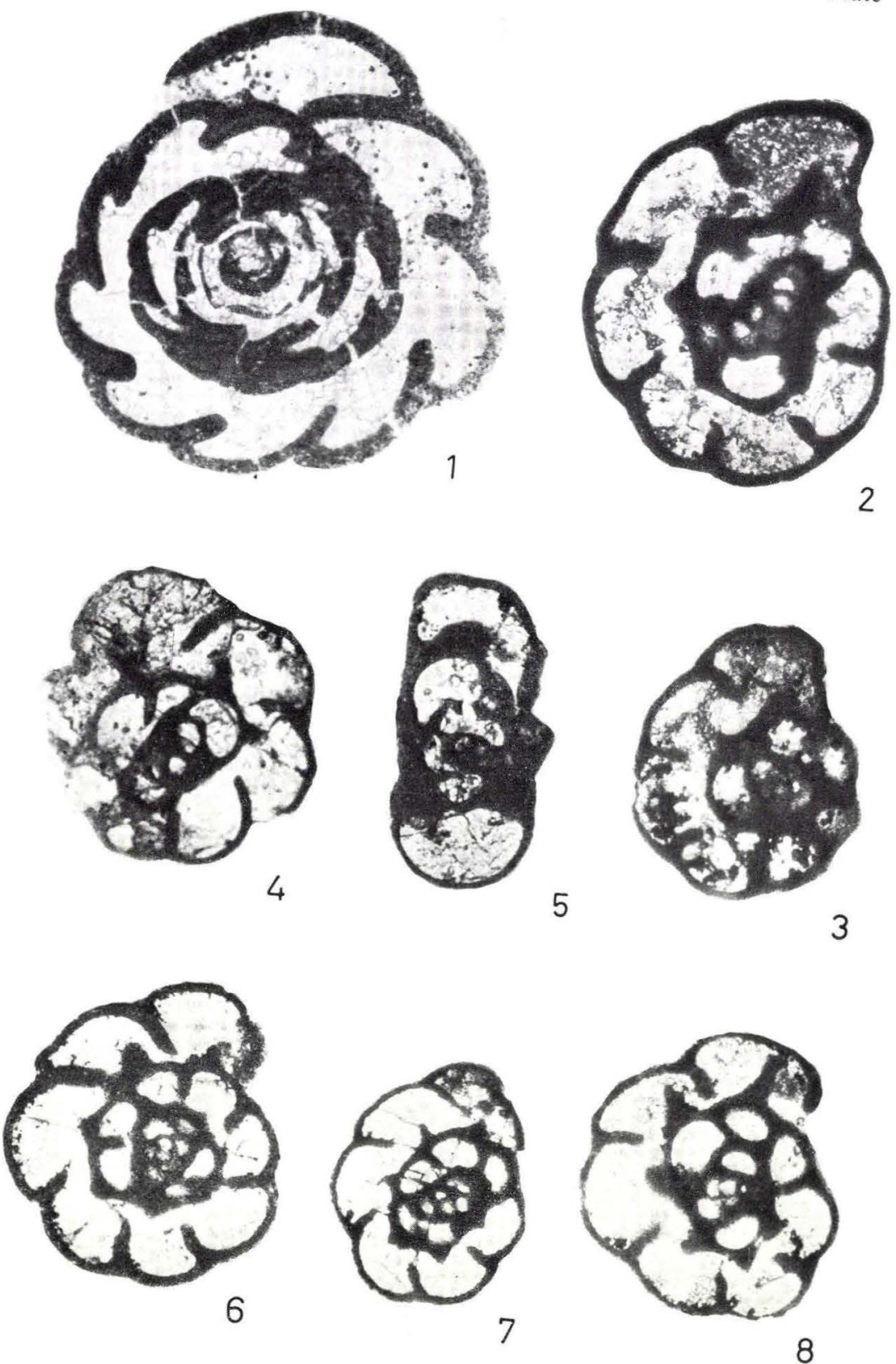
PLATE VIII

$60 \times$

Figs. 1-2. Endothyra cf. bradyi Mikhailov 1939

Fig. 1: Depth 7880'-7890'

Diameter: $0.74 \mathrm{~mm}$.

Fig. 2: Depth $7700^{\prime} 0^{\prime \prime}-5 "$

Diameter: $0.87 \mathrm{~mm}$.

Figs. 3-6. Endothyra sp. 1

Fig. 3: Depth 7880'-7890'

Diameter: $0.75 \mathrm{~mm}$.

Fig. 4: Depth 7712' 7"-7713'

Diameter: $0.70 \mathrm{~mm}$.

Fig. 5: Depth 7070'-7080'

Diameter: $0.63 \mathrm{~mm}$.

Fig. 6: Depth 7880'-7890'

Diameter: $0.84 \mathrm{~mm}$, breadth: $0.46 \mathrm{~mm}$.

Fig. 7. Endothyra sp. 2

Depth $7210^{\prime}-7220^{\prime}$

Diameter: $0.63 \mathrm{~mm}$.
D.G.U. Text Catalogue No. page

1970-OM-66

1970-OM-67

1970-OM-68

1970-OM-69

1970-OM-70

1970-OM-71
1970-OM-72 
Plate VIII

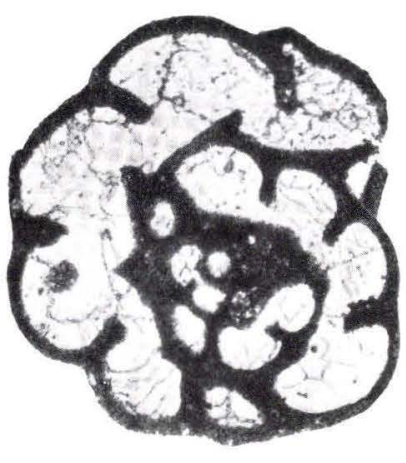

1
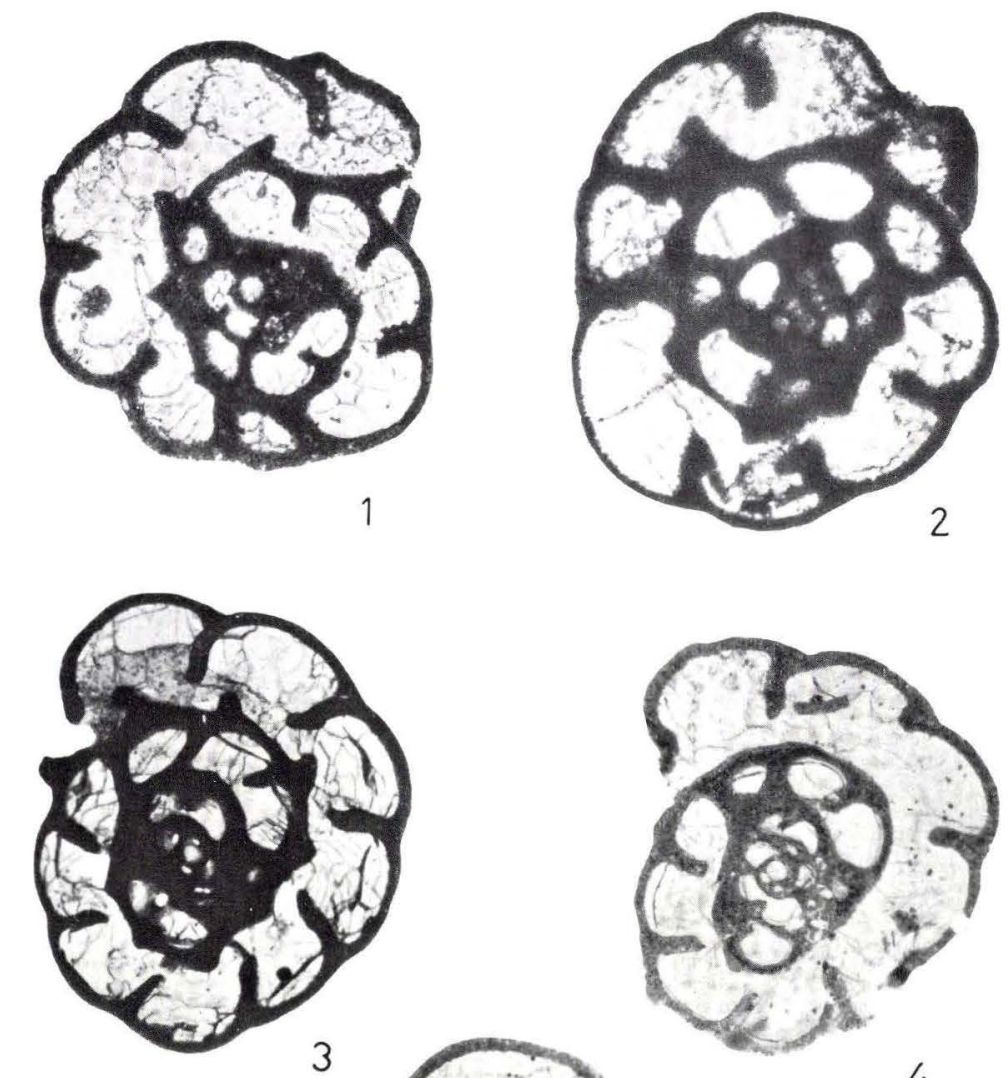

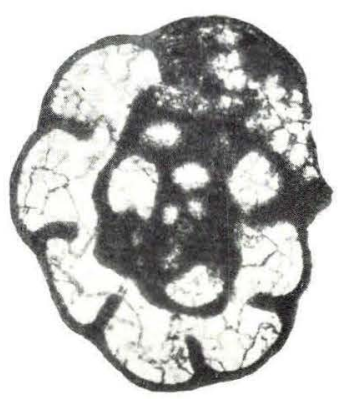

5

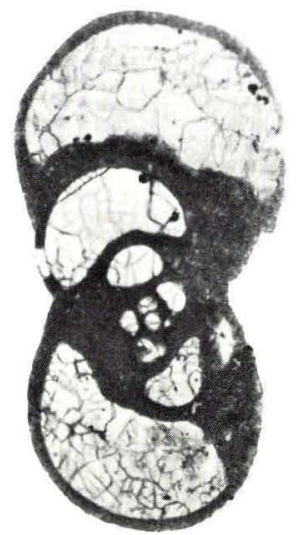

6
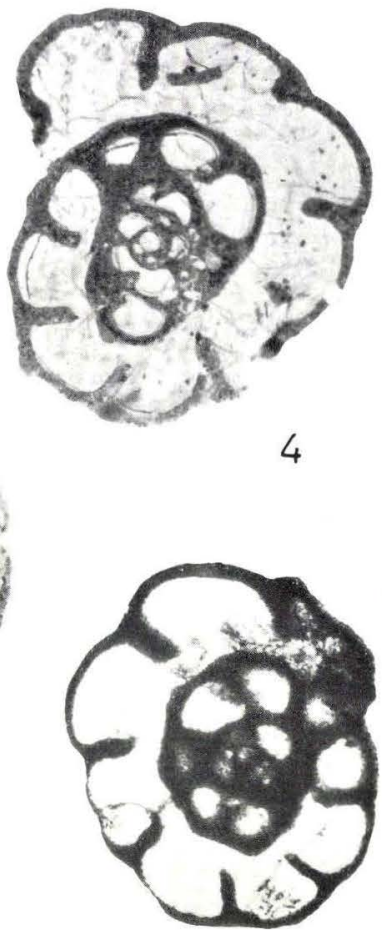

7 
D.G.U. Text Catalogue No. page

Figs. 1-2. Endothyra sp. 2

Fig. 1: Depth 7160'-7170'

1970-OM-73

Diameter: $0.57 \mathrm{~mm}$, breadth: 0.38 (?) $\mathrm{mm}$.

Fig. 2: Depth 7160'-7170'

Diameter: 0.48 (?) $\mathrm{mm}$.

Figs. 3-4. Endothyra convexa regularis RAus.-ČERN. 1948

Fig. 3: Depth 6930'-6940' 1970-OM-75

Diameter: $0.36 \mathrm{~mm}$.

Fig. 4: Depth 6930'-6940'

1970-OM-76

Diameter: $0.30 \mathrm{~mm}$, breadth: $0.18 \mathrm{~mm}$.

Figs. 5-7. Endothyra aff. costifera Grozd. \& LeBED. 1954

Fig. 5: Depth 7930'-7940' 1970-OM-77

Diameter: $0.56 \mathrm{~mm}$.

Fig. 6: Depth $8170^{\prime}-8173^{\prime}$

1970-OM-78

Diameter: $0.67 \mathrm{~mm}$, breadth: $0.32 \mathrm{~mm}$.

Fig. 7: Depth 6930'-6940'

1970-OM-79

Diameter: $0.43 \mathrm{~mm}$.

Figs. 8-10. Endothyra spp. (F-37)

Fig. 8: Depth 7700' $0^{\prime \prime}-5^{\prime \prime}$

1970-OM-80

Diameter: 1.14 (?) $\mathrm{mm}$.

Fig. 9: Depth 8260'-8270'

1970-OM-81

Diameter: $0.48 \mathrm{~mm}$.

Fig. 10: Depth 7930'-7940'

1970-OM-82

Diameter: $0.50 \mathrm{~mm}$.

Phot. O. Neergaard Rasmussen (fig. 1, 2, 4-7, 9, 10) and the author (figs. 3 \& 8). 
Plate IX
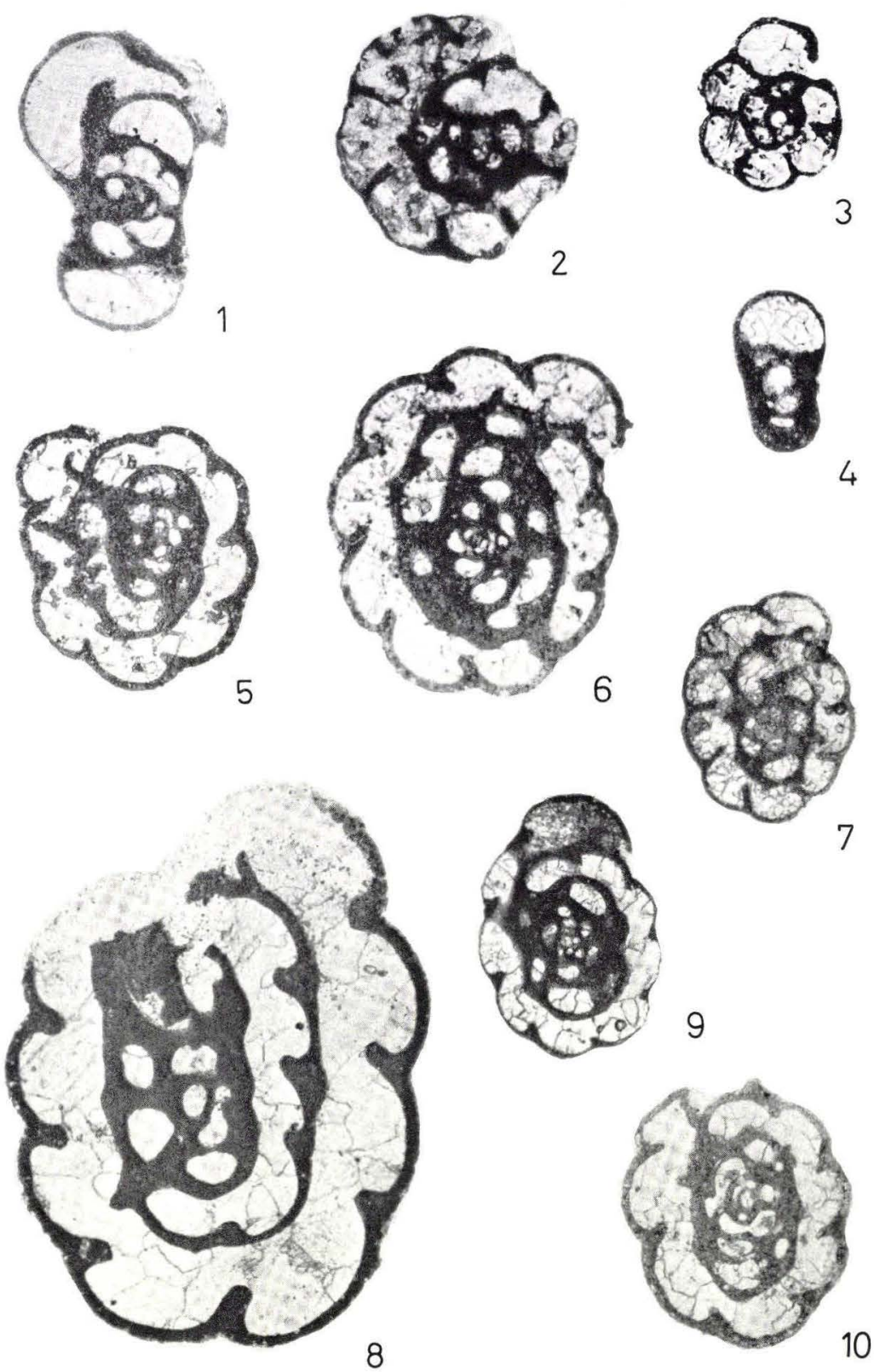
Figs. 1-7. Endothyra danica n. sp.

D.G.U. Text Catalogue No. page

Fig. 1: HOLOTYPE. Depth $7780^{\prime}-7790^{\prime}$

Diameter: $0.49 \mathrm{~mm}$.

Fig. 2: Depth $7780^{\prime}-7790^{\prime}$

1970-OM-83

Diameter: $0.47 \mathrm{~mm}$, breadth: $0.25 \mathrm{~mm}$.

Fig. 3: Depth 7880'-7890'

1970-OM-84

Diameter: $0.53 \mathrm{~mm}$.

Fig. 4: Depth 7700' $0^{\prime \prime}-5^{\prime \prime}$

1970-OM-85

Diameter: 0.55 (?) $\mathrm{mm}$.

Fig. 5: Depth $7780^{\prime}-7790^{\prime}$

1970-OM-86

Diameter: $0.44 \mathrm{~mm}$, breadth: $0.24 \mathrm{~mm}$.

Fig. 6: Depth 7930'-7940'

1970-OM-87

Diameter: $0.53 \mathrm{~mm}$.

Fig. 7: Depth 7700' 0"-5"

1970-OM-88

Diameter: 0.48 (?) $\mathrm{mm}$.

Figs. 8-9. Endothyra cf. delepinei CONIL \& Lys 1964

Fig. 8: Depth 7070'-7080' 1970-OM-90

Diameter: $0.53 \mathrm{~mm}$, breadth: $0.31 \mathrm{~mm}$.

Fig. 9: Depth $7070^{\prime}-7080^{\prime}$

1970-OM-91

Diameter: $0.55 \mathrm{~mm}$.

Figs. 10-12. Endothyra aff. prisca RaUS.-ČERN. \& REITL. 1936

Fig. 10: Depth 7930'-7940'

1970-OM-92

Diameter: $0.33 \mathrm{~mm}$.

Fig. 11: Depth 7712' 7"-7713'

1970-OM-93

Diameter: $0.40 \mathrm{~mm}$.

Fig. 12: Depth 7880'-7890'

1970-OM-94

Diameter: $0.39 \mathrm{~mm}$.

Fig. 13. Endothyra sp. 3

1970-OM-95

Depth 7880'-7890'.

Diameter: $0.39 \mathrm{~mm}$.

Phot. O. Nefrgaard Rasmussen (figs. 1-4, 6, 8, 10-13) and the author (figs. 5, 7, 9). 
Plate X
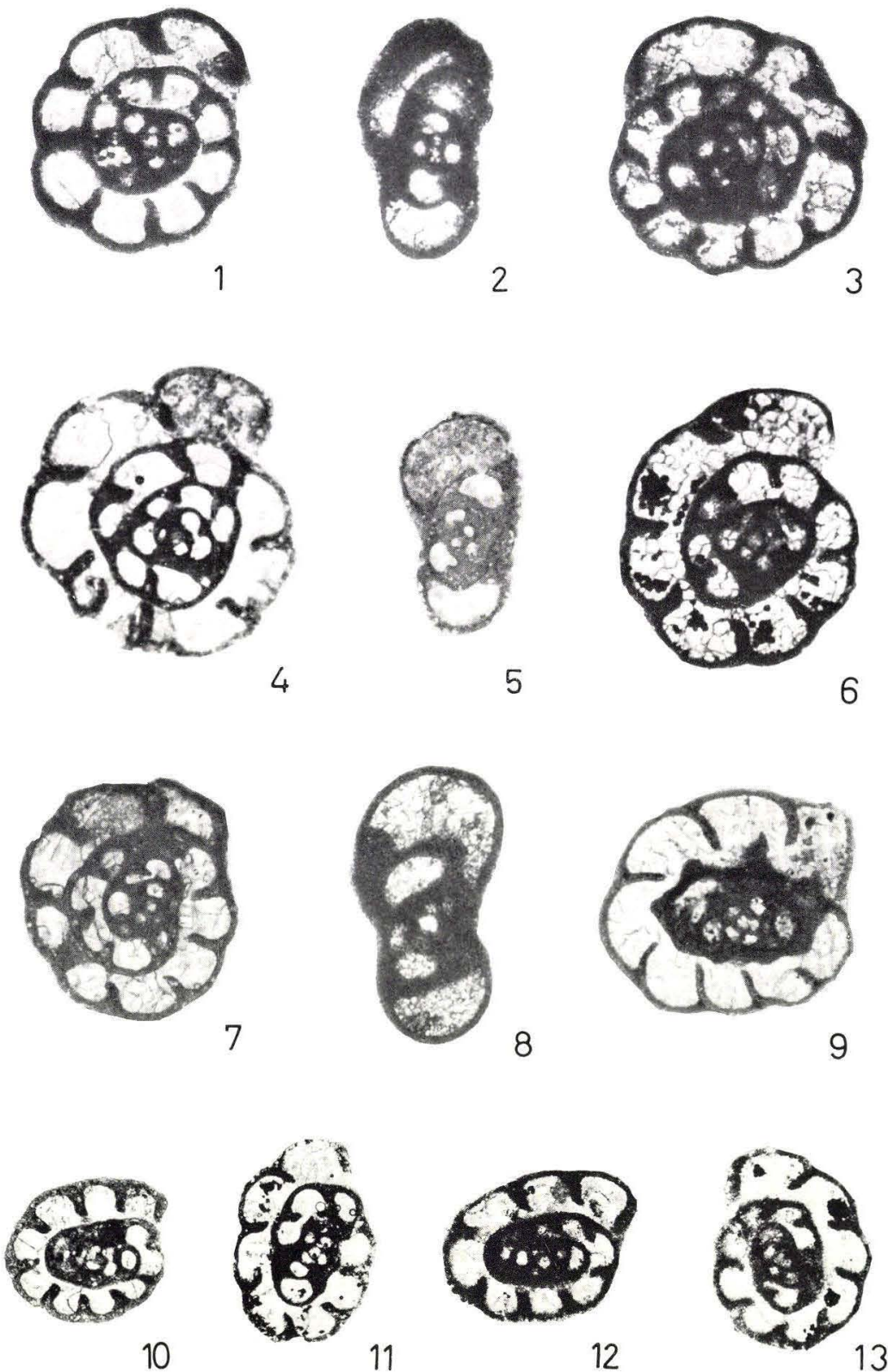
PLATE XI

$60 \times$

D.G.U. Text

Catalogue No. page

Figs. 1-6. Endothyra michoti spinata n. subsp.

Fig. 1: Depth 7700' $0^{\prime \prime}-5^{\prime \prime}$

1970-OM-96

Diameter: $0.95 \mathrm{~mm}$.

Fig. 2: HOLOTYPE. Depth 7700' 0"-5"

1970-OM-97

Diameter: $0.98 \mathrm{~mm}$.

Fig. 3: Depth 7700' 0"-5"

1970-OM-98

Diameter: $1.06 \mathrm{~mm}$.

Fig. 4: Depth $7700^{\prime} 0^{\prime \prime}-5^{\prime \prime}$

1970-OM-99

Diameter: $1.20 \mathrm{~mm}$, breadth: $0.46 \mathrm{~mm}$.

Fig. 5: Depth $7690^{\prime} 2^{\prime \prime}-7^{\prime \prime}$

1970-OM-100

Diameter: $0.67 \mathrm{~mm}$.

Fig. 6: Juvenile specimen. Depth $7700^{\prime} 0^{\prime \prime}-5^{\prime \prime}$

1970-OM-101

Diameter: $0.30 \mathrm{~mm}$.

Phot. O. Neergatrd Rasmussen (figs. 2-4) and the author (figs. 1, 5, 6). 

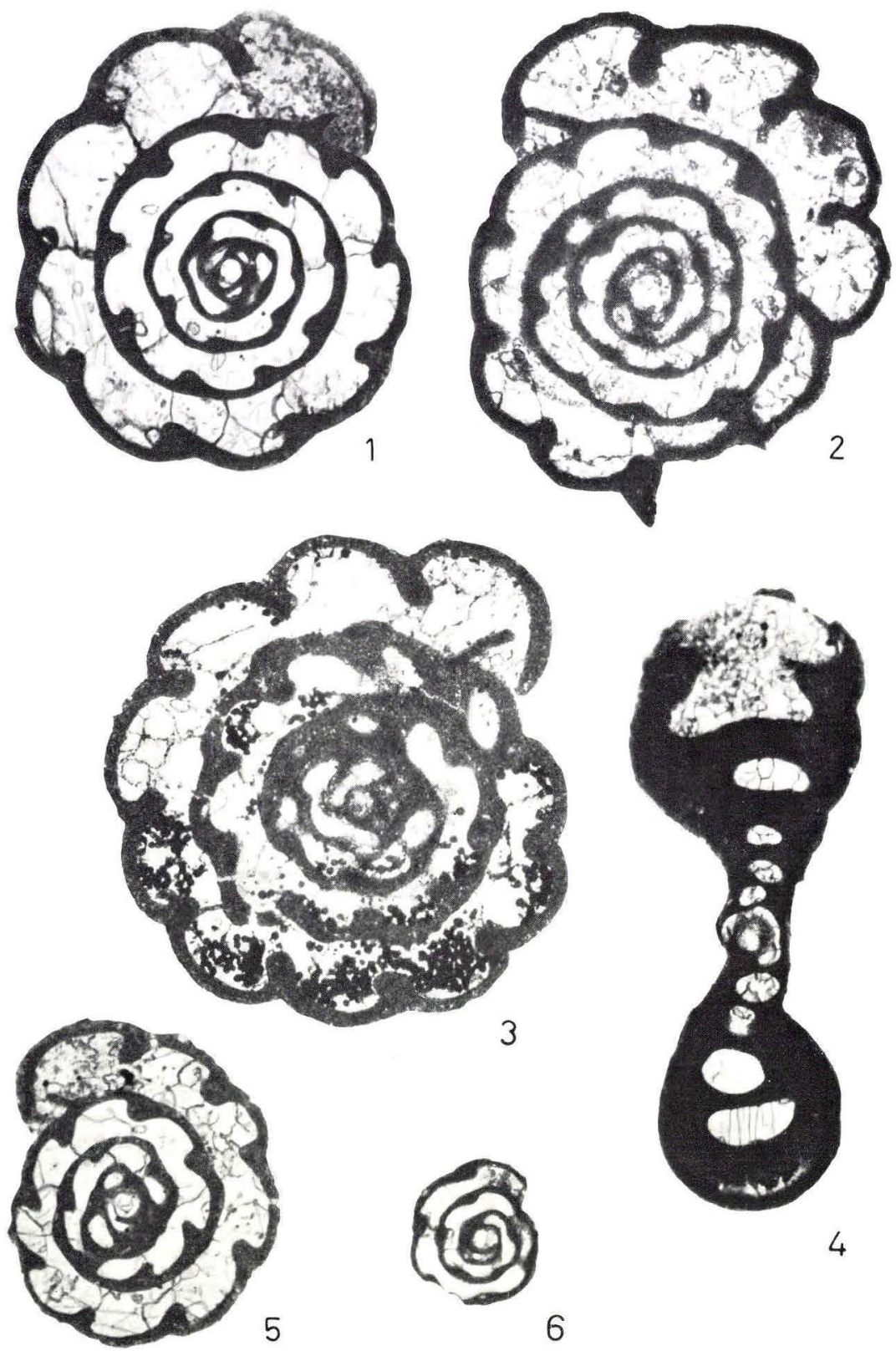

3

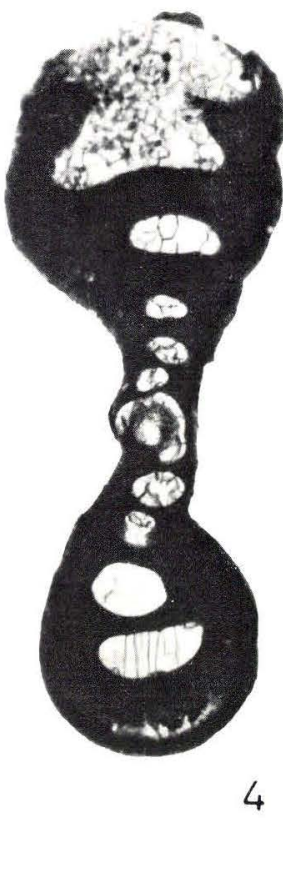

6 
Fig. 1. Endothyra michoti spinata n. subsp.

Depth 7700' 0" $-5 "$.

Fig. 2. Endothyra sp. (F-13)

Depth 6800'-6810'.

Diameter: $0.41 \mathrm{~mm}$.

Figs. 3-11. Endothyra recta LipINA 1955

Fig. 3: Depth 8260'-8270'

1970-OM-104

Diameter: $0.44 \mathrm{~mm}$, breadth: $0.23 \mathrm{~mm}$.

Fig. 4: Depth $8260^{\prime}-8270^{\prime}$

1970-OM-105

Breadth: $0.22 \mathrm{~mm}$.

Fig. 5: Depth $8370^{\prime}-8380^{\prime}$

1970-OM-106

Diameter: $0.52 \mathrm{~mm}$, breadth: $0.32 \mathrm{~mm}$.

Fig. 6: Depth 7830'-7840'

1970-OM-107

Diameter: $0.41 \mathrm{~mm}$.

Fig. 7: Depth 8210'-8220'

1970-OM-108

Diameter: $0.45 \mathrm{~mm}$.

Fig. 8: Depth 8260'-8270'

1970-OM-109

Diameter: $0.44 \mathrm{~mm}$.

Fig. 9: Depth 8370'-8380'

1970-OM-110

Diameter: $0.38 \mathrm{~mm}$.

Fig. 10: Depth 8370'-8380'

1970-OM-111

Diameter: $0.48 \mathrm{~mm}$, breadth: $0.24 \mathrm{~mm}$.

Fig. 11: Depth 8370'-8380'

1970-OM-112

Diameter: $0.57 \mathrm{~mm}$, breadth: $0.31 \mathrm{~mm}$.

Figs. 12-13. Endothyra sp. 4

Fig. 12: Depth 8310'-8320'

Diameter: $0.51 \mathrm{~mm}$.

Fig. 13: Depth 8310'-8320'

1970-OM-114

Diameter: $0.54 \mathrm{~mm}$, breadth: $0.27 \mathrm{~mm}$.

Phot. O. NeergaArd Rasmussen. 

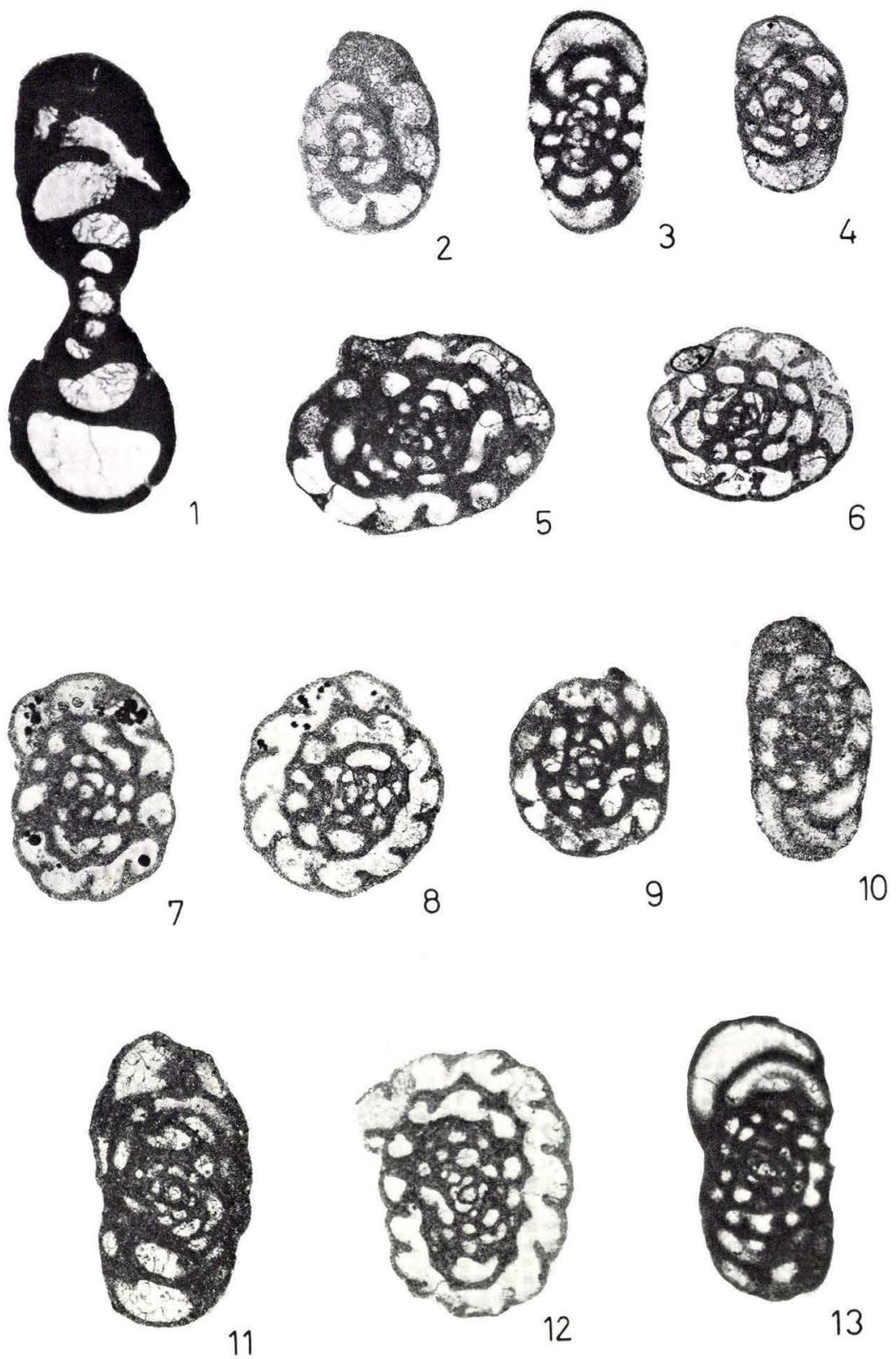

11

12 
D.G.U. Text

Fig. 1. Endothyra sp. 5

Depth $6800^{\prime}-6810^{\prime}$.

Diameter: $0.60 \mathrm{~mm}$.

Figs. 2-3. Endothyra sp. 6

Fig. 2: Depth $8280^{\prime}-8290^{\prime}$

1970-OM-116

Diameter: $0.45 \mathrm{~mm}$.

Fig. 3: Depth $8290^{\prime}-8300^{\prime}$

1970-OM-117

Diameter: $0.36 \mathrm{~mm}$, breadth: $0.11 \mathrm{~mm}$.

Figs. 4-7. Endothyra spp. (F-29 \& F-44)

Fig. 4: Depth 7408'-7420'

1970-OM-118

Diameter: $0.44 \mathrm{~mm}$, breadth: $0.20 \mathrm{~mm}$.

Fig. 5: Depth 7210'-7220'

1970-OM-119

Diameter: $0.42 \mathrm{~mm}$.

Fig. 6: Depth 7210'-7220'

1970-OM-120

Diameter: $0.48 \mathrm{~mm}$, breadth: $0.19 \mathrm{~mm}$.

Fig. 7: Depth 7408'-7420'

1970-OM-121

Diameter: $0.50 \mathrm{~mm}$.

Fig. 8. Paraendothyra cummingsi (CoNIL \& Lys 1964)

1970-OM-122

Depth $8280^{\prime}-8290^{\prime}$.

Diameter: $0.60 \mathrm{~mm}$.

Figs. 9-10. Paraendothyra nalivkini CHERnYSHEVA 1940

Fig. 9: Depth 8300'-8310'

Diameter: $0.68 \mathrm{~mm}$, breadth: $0.26 \mathrm{~mm}$.

Fig. 10: Depth $8300^{\prime}-8310^{\prime}$

1970-OM-124

Diameter: $0.70 \mathrm{~mm}$, breadth: $0.29 \mathrm{~mm}$.

Figs. 11-14. Endostaffella? sp. 1

Fig. 11: Depth $6800^{\prime}-6810^{\prime}$

1970-OM-125

Diameter: $0.43 \mathrm{~mm}$, breadth: $0.22 \mathrm{~mm}$

Fig. 12: Depth $6800^{\prime}-6810^{\prime}$

1970-OM-126

Diameter: $0.43 \mathrm{~mm}$.

Fig. 13: Depth 6930'-6940'

1970-OM-127

Diameter: $0.41 \mathrm{~mm}$, breadth: $0.24 \mathrm{~mm}$.

Fig. 14: Depth 6800'-6810'

1970-OM-128

Diameter: $0.39 \mathrm{~mm}$.

Phot. O. Neergaard Rasmussen (figs. 1-5, 7, 10-14) and the author (figs. 6, 8, 9). 

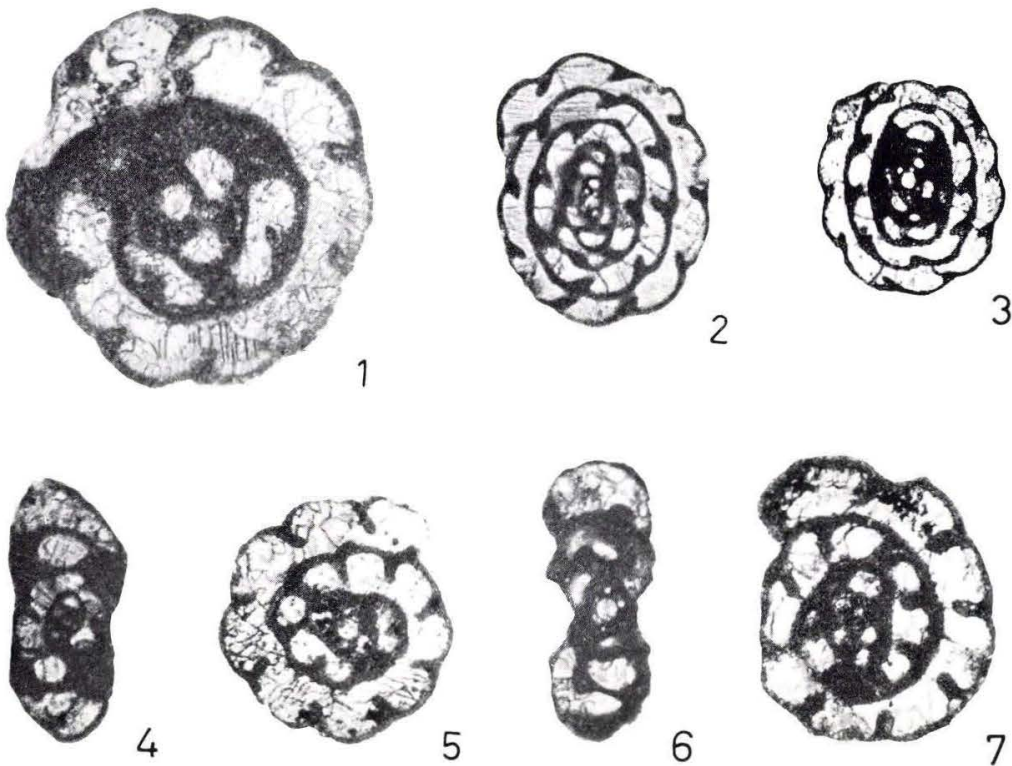

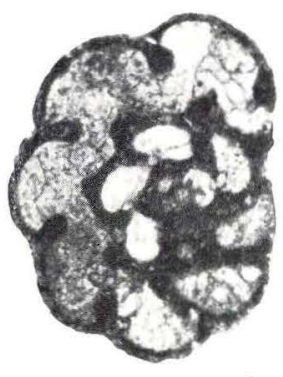

8

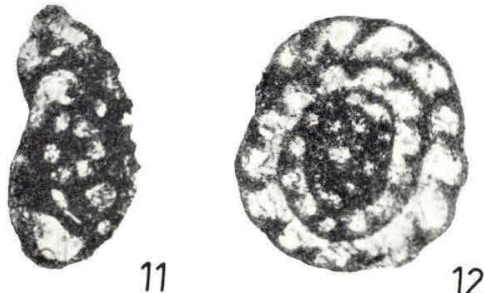

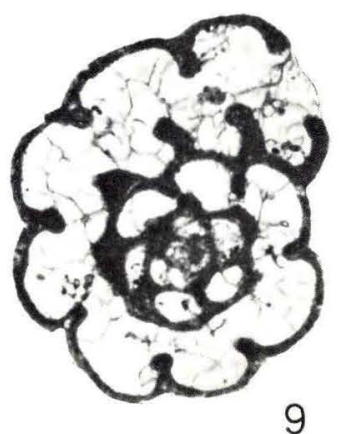
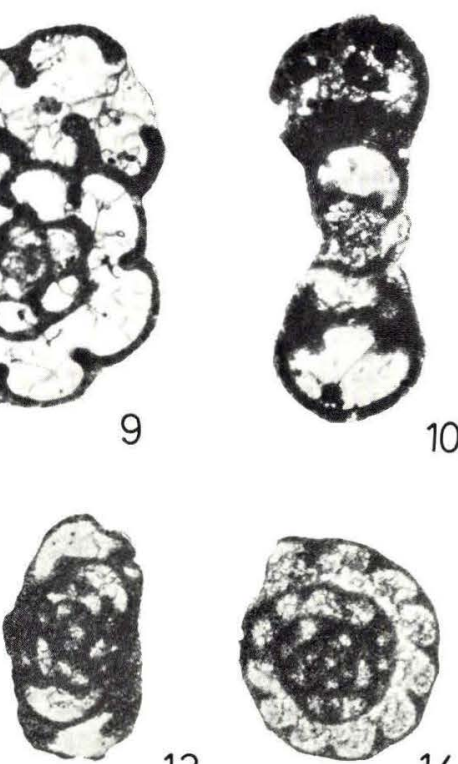

13

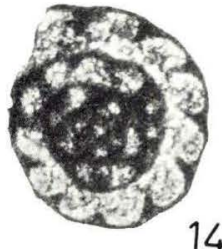


Figs. 1-3. Endostaffella? sp. 1

D.G.U. Text Catalogue No. page

Fig. 1: Depth 6800'-6810' 66

Diameter: $0.57 \mathrm{~mm}$, breadth: $0.33 \mathrm{~mm}$.

Fig. 2: Depth 6930'-6940'

Diameter: $0.51 \mathrm{~mm}$, breadth: $0.27 \mathrm{~mm}$.

Fig. 3: Depth 6930'-6940'

Diameter: $0.47 \mathrm{~mm}$.

1970-OM-129

1970-OM-130

1970-OM-131

Figs. 4-7. Endostaffella ? sp. 2

Fig. 4: Depth 6898'-6910'

1970-OM-132

Diameter: $0.46 \mathrm{~mm}$, breadth: $0.20 \mathrm{~mm}$.

Fig. 5: Depth 6930'-6940'

1970-OM-133

Diameter: $0.51 \mathrm{~mm}$.

Fig. 6: Depth 6930'-6940'

1970-OM-134

Diameter: $0.42 \mathrm{~mm}$.

Fig. 7: Depth $6800^{\prime}-6810^{\prime}$

1970-OM-135

Diameter: $0.47 \mathrm{~mm}$.

Figs. 8-9. Eostaffella sp. 1

Fig. 8: Depth 7686'

1970-OM-136

Diameter: $0.82 \mathrm{~mm}$, breadth: $0.39 \mathrm{~mm}$.

Fig. 9: Depth 7686'

1970-OM-137

Diameter: $0.80 \mathrm{~mm}$.

Figs. 10-11. Haplophragmina loeblichi CoNIL \& LYS 1968

Fig. 10: Depth 7920'-7930' $\ldots \ldots \ldots$
Length: $1.09 \mathrm{~mm}$, diameter: $0.36 \mathrm{~mm}$.

Fig. 11: Depth $8290^{\prime}-8300^{\prime} \ldots \ldots \ldots \ldots \ldots \ldots \ldots \ldots$

Length: $0.76 \mathrm{~mm}$, diameter: 0.41 (?) $\mathrm{mm}$.

Phot. O. Nefrgaard Rasmussen. 

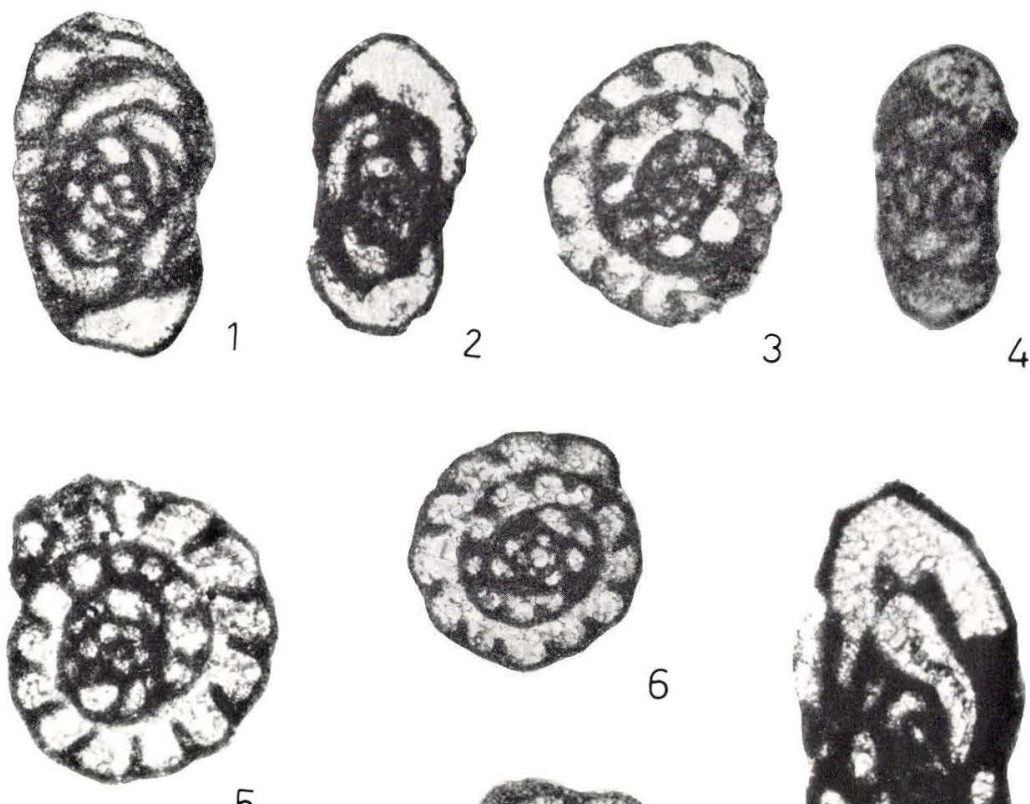

6
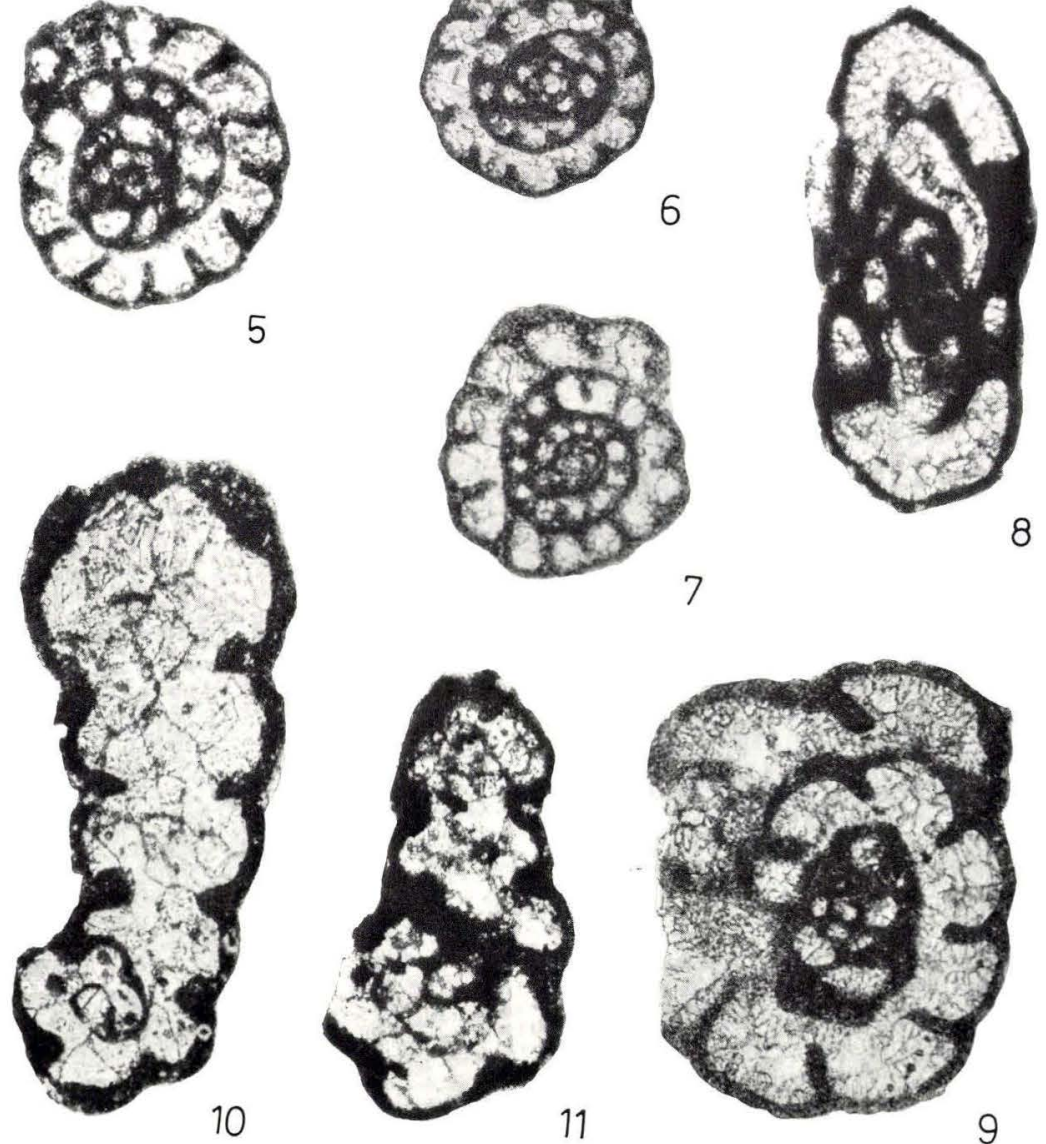
Fig. 1. Earlandia elegans (RAUS.-ČERN. \& REITL. 1937) . . . . . 1970-OM-140 32 Depth 7920'-7930'.

Length: $0.33 \mathrm{~mm}$, diameter of proloculum: $0.11 \mathrm{~mm}$.

Figs. 2-3. Tetrataxis cf. pusillus ConIL \& LYS $1964 \ldots \ldots \ldots$ 1970-OM-141 34 Depth 7712' 7'-7713'.

Diameter: $0.32 \mathrm{~mm}$, height: $0.18 \mathrm{~mm}$.

Fig. 2: Side view.

Fig. 3: Spiral side.

Fig. 4. Brunsiina pseudopulchra (LIPINA 1955)

Depth 8240'-8250'.

Diameter: $0.51 \mathrm{~mm}$, breadth: $0.11 \mathrm{~mm}$.

Fig. 5. Brunsiina spirillinoides (GRozD. \& GleB. 1948) . . . . .

Depth 8440'.

Diameter: $0.59 \mathrm{~mm}$, breadth: $0.12 \mathrm{~mm}$.

Figs. 6-7. "Palaeospiroplectammina" mellina (MALAKHova 1965)

Depth 7980'-7990'.

Length: $0.34 \mathrm{~mm}$, breadth: $0.24 \mathrm{~mm}$.

Fig. 6: Side view.

Fig. 7: Marginal view.

Figs. 8-9. "Palaeospiroplectammina" mellina (MalaKHova 1965)

Depth 7700' 0"-5".

Length: $0.51 \mathrm{~mm}$, breadth: $0.24 \mathrm{~mm}$.

Fig. 8: Marginal view.

Fig. 9: Side view.

Figs. 10-11. Palaeospiroplectammina aff. tchernyshinensis

(LiPINA 1948) 1970-OM-146 46

Depth $8290^{\prime}-8300^{\prime}$.

Length: $0.57 \mathrm{~mm}$, breadth: $0.23 \mathrm{~mm}$.

Fig. 10: Side view.

Fig. 11: Marginal view.

Figs. 12-13. Palaeospiroplectammina venusta (VDovenKo 1954)

Depth 8350'-8360'.

Length: $0.48 \mathrm{~mm}$, breadth: $0.20 \mathrm{~mm}$.

Fig. 12: Side view.

Fig. 13: Marginal view.

Phot. O. NeERgaARd Rasmussen. 
Plate XV

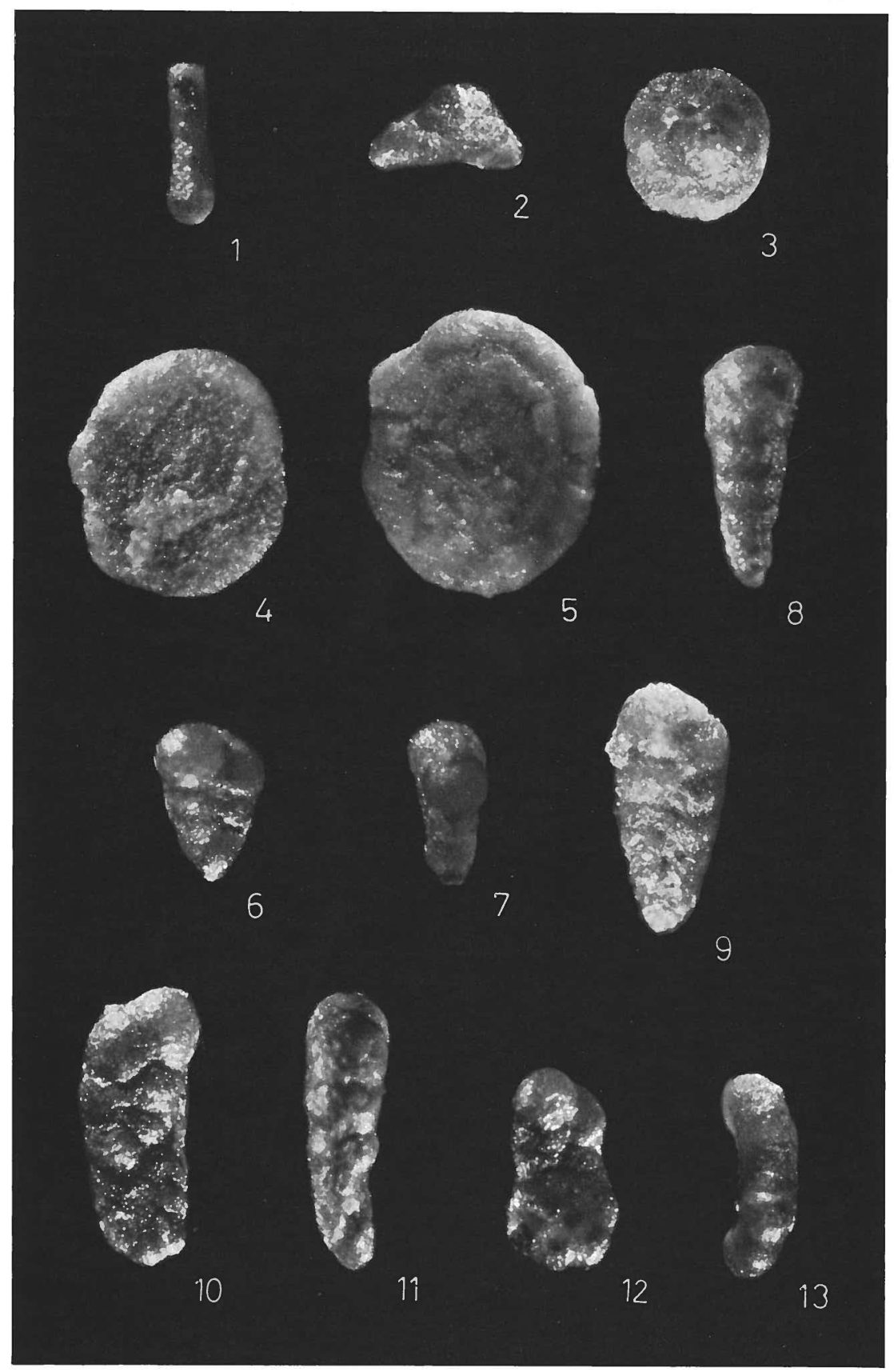




\section{PLATE XVI \\ $60 \times$}

Figs. 1-2. Palaeospiroplectammina diversa (CHERN. 1948)... Depth 7930'-7940'.

Length: $0.91 \mathrm{~mm}$, breadth: $0.56 \mathrm{~mm}$.

Fig. 1: Side view.

Fig. 2: Marginal view.

Fig. 3. Palaeospiroplectammina diversa (CHERN. 1948) .....

1970-OM-149

41

Depth 7940'-7950'.

Length: $0.65 \mathrm{~mm}$, breadth: $0.66 \mathrm{~mm}$.

Fig. 4. Septabrunsiina spissusvoluta n. sp.

1970-OM-150

50

Depth 8400'-8410'.

Diameter: $0.32 \mathrm{~mm}$, breadth: $0.11 \mathrm{~mm}$.

Figs. 5-6. Endothyra cf. bradyi Mikhailov 1939

1970-OM-151

52

Depth $7880^{\prime}-7890^{\prime}$.

Diameter: $0.60 \mathrm{~mm}$, breadth: $0.30 \mathrm{~mm}$.

Fig. 5: Side view.

Fig. 6: Marginal view.

Figs. 7-8. Endothyra cf. bradyi Mikhailov 1939

1970-OM-152 52

Diameter: $0.58 \mathrm{~mm}$, breadth: $0.36 \mathrm{~mm}$.

Fig. 7: Side view.

Fig. 8: Marginal view.

Phot. O. Neergaard Rasmussen. 





Fig. 1. Endothyra sp. 1

Depth 7880'-7890'.

Diameter: $0.75 \mathrm{~mm}$, breadth: $0.37 \mathrm{~mm}$.

Figs. 2-3. Endothyra sp. 1

Depth 7980'-7990'.

Diameter: $0.76 \mathrm{~mm}$, breadth: $0.40 \mathrm{~mm}$.

Fig. 2: Side view.

Fig. 3: Marginal view.

Figs. 4-5. Endothyra sp. 2

Depth 7160'-7170'

Diameter: $0.65 \mathrm{~mm}$, breadth: $0.40 \mathrm{~mm}$.

Fig. 4: Side view.

Fig. 5: Marginal view.

Figs. 6-7. Endothyra danica n. sp.

Depth 7780'-7790'.

Diameter: $0.47 \mathrm{~mm}$, breadth: $0.27 \mathrm{~mm}$.

Fig. 6: Side view.

Fig. 7: Marginal view.

Figs. 8-9. Endothyra convexa regularis RAUS.-ČERN. 1948 .

Depth 6930'-6940'.

Diameter: $0.49 \mathrm{~mm}$, breadth: $0.32 \mathrm{~mm}$.

Fig. 8: Marginal view.

Fig. 9: Side view.

Phot. O. NeergaArd Rasmussen. 
Plate XVII

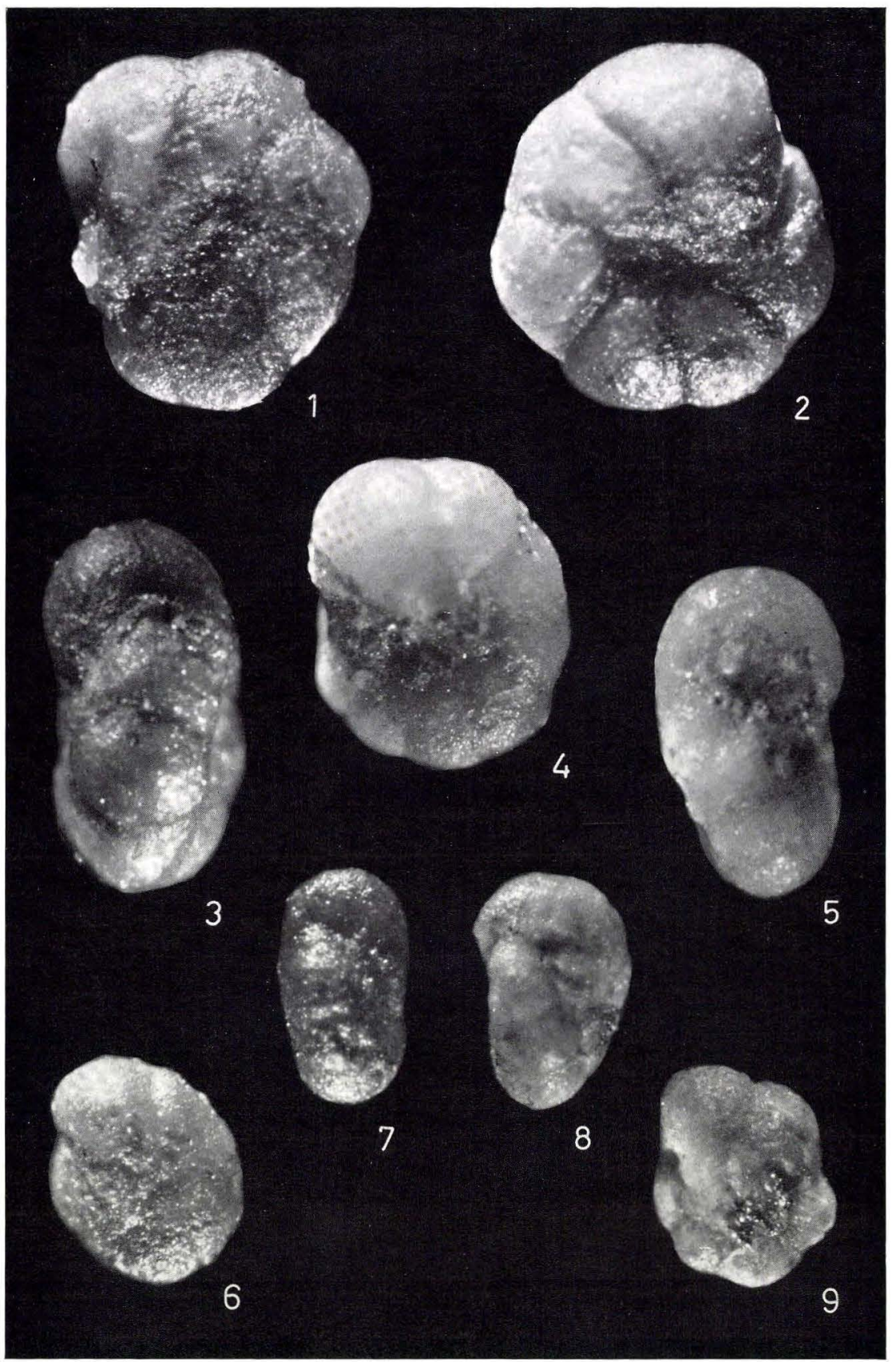


PLATE XVIII

$60 \times$

Figs. 1-2. Endothyra michoti spinata n. subsp.

Depth $7830^{\prime}-7840^{\prime}$.

Diameter: $0.91 \mathrm{~mm}$, breadth: $0.36 \mathrm{~mm}$.

Fig. 1: Side view.

Fig. 2: Marginal view.

Figs. 3-5. Endothyra aff. prisca Raus.-ČERN. \& ReITL. 1936 . . Depth 7830'-7840'.

Diameter: $0.44 \mathrm{~mm}$, breadth: $0.28 \mathrm{~mm}$.

Fig. 3: Involute side.

Fig. 4: Evolute side.

Fig. 5: Marginal view.

Figs. 6-8. Endothyra recta LIPINA 1955

1970-OM-160

61

Depth 8260'-8270'.

Diameter: $0.38 \mathrm{~mm}$, breadth: $0.28 \mathrm{~mm}$.

Fig. 6: Involute side.

Fig. 7: Evolute side.

Fig. 8: Marginal view.

Figs. 9-11. Endothyra recta LIPINA 1955

1970-OM-161 61

Depth 8260'-8270'.

Diameter: $0.47 \mathrm{~mm}$, breadth: $0.22 \mathrm{~mm}$.

Fig. 9: Involute side.

Fig. 10: Evolute side.

Fig. 11: Marginal view.

Phot. O. NeErgaard Rasmussen.
D.G.U. Text Catalogue No. page 1970-OM-158 59 60 
Plate XVIII

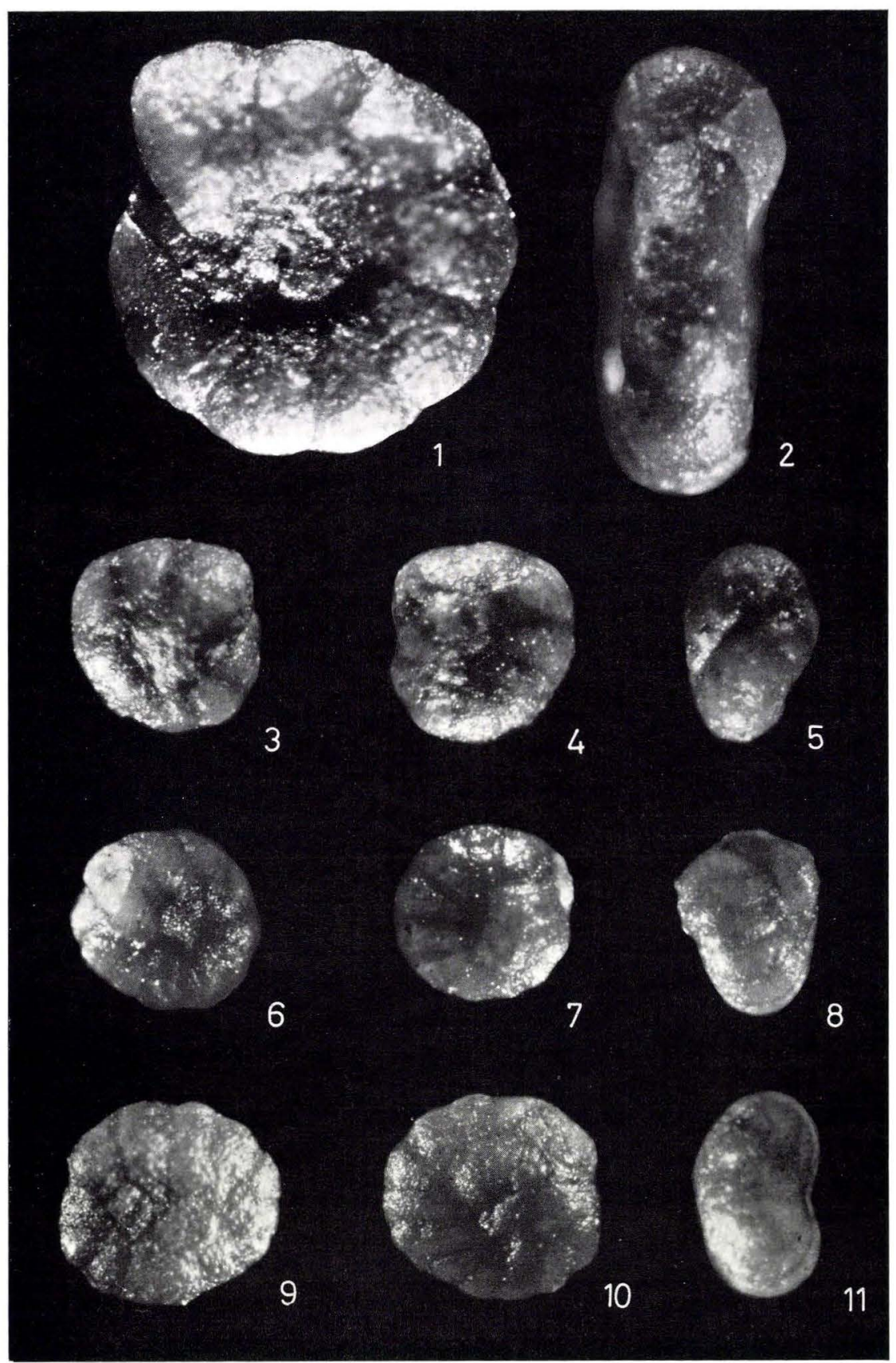


Figs. 1-3. Endothyra recta LipINA 1955

Depth $8260^{\prime}-8270^{\prime}$.

Diameter: $0.51 \mathrm{~mm}$, breadth: $0.29 \mathrm{~mm}$.

Fig. 1: Involute side.

Fig. 2: Evolute side.

Fig. 3: Marginal view.

Figs. 4-6. Endothyra sp. 4

Depth $8310^{\prime}-8320^{\prime}$.

Diameter: $0.71 \mathrm{~mm}$, breadth: $0.28 \mathrm{~mm}$.

Fig. 4: Involute-evolute side.

Fig. 5: Evolute side.

Fig. 6: Marginal view.

Figs. 7-9. Endothyra cf. delepinei CONIL \& Lys 1964...... .

Depth 7070'-7080'.

Diameter: $0.48 \mathrm{~mm}$, breadth: $0.28 \mathrm{~mm}$.

Fig. 7: Involute side.

Fig. 8: Evolute side.

Fig. 9: Marginal view.

Fig. 10. Haplophragmina loeblichi ConIL \& Lys 1968

Depth 7900'-7910'.

Length: $0.50 \mathrm{~mm}$, diameter: $0.27 \mathrm{~mm}$.

Fig. 11. Endostaffella ? sp. 1

Depth 6800'-6810'

Diameter: $0.53 \mathrm{~mm}$, breadth: $0.32 \mathrm{~mm}$.

Fig. 12. Endostaffella? sp. 2

Depth 6800'-6810'.

Diameter: $0.38 \mathrm{~mm}$, breadth: $0.20 \mathrm{~mm}$.

Phot. O. Neergaard Rasmussen. 
Plate XIX

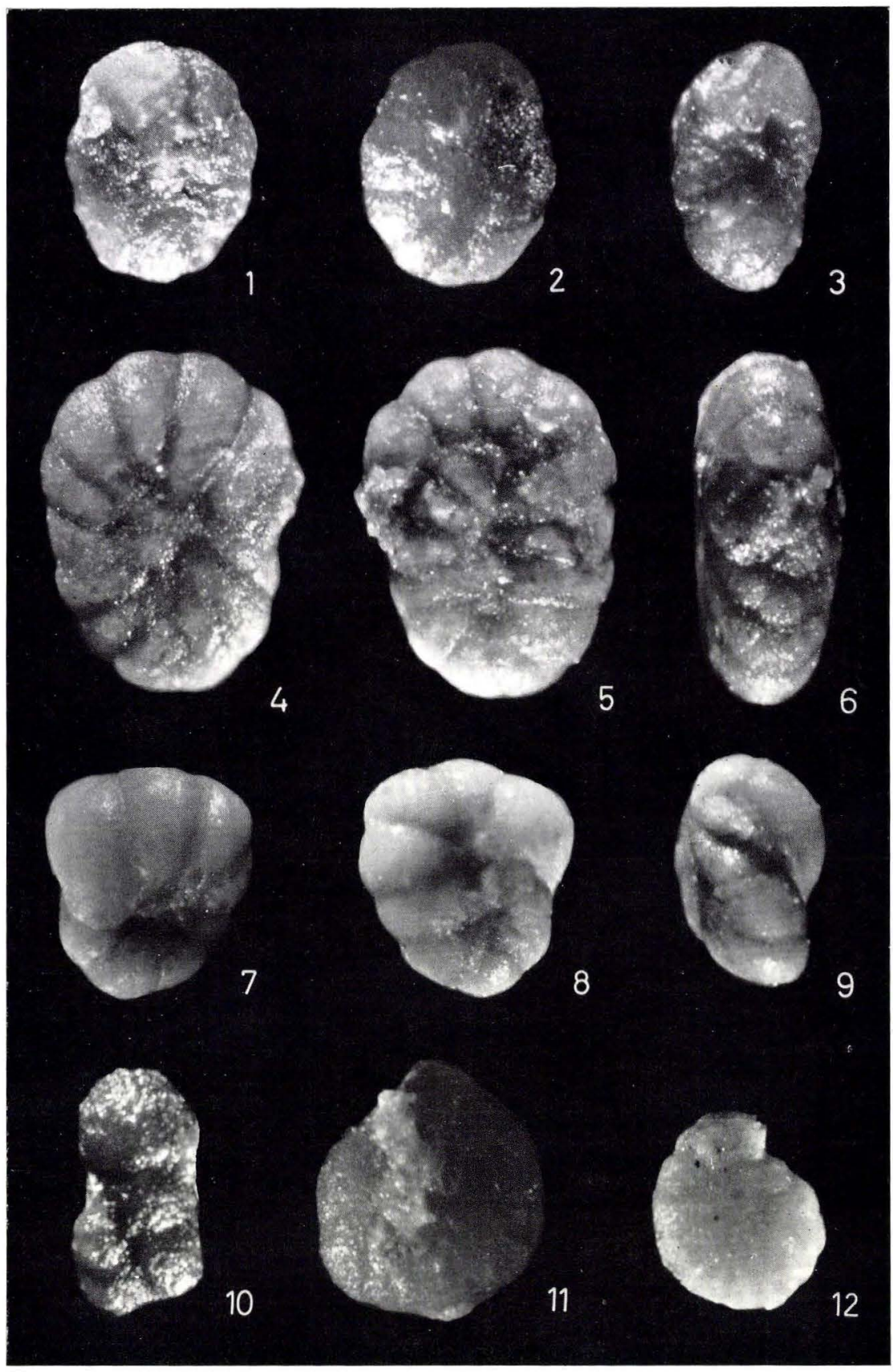


PLATE XX

D.G.U. Text

Catalogue No, page

Figs. 1-2. Eostaffella sp. 1

1970-OM-168 68

Depth 7686'.

Diameter: $0.87 \mathrm{~mm}$, breadth: $0.44 \mathrm{~mm}$.

Fig. 1: Side view. $60 \times$.

Fig. 2: Marginal view. $60 \times$.

Fig. 3. Thin-section of the limestone from core No. 1 .

Depth 6861' 5". $22 \times$.

Phot. O. NeERgaArd Rasmussen. 

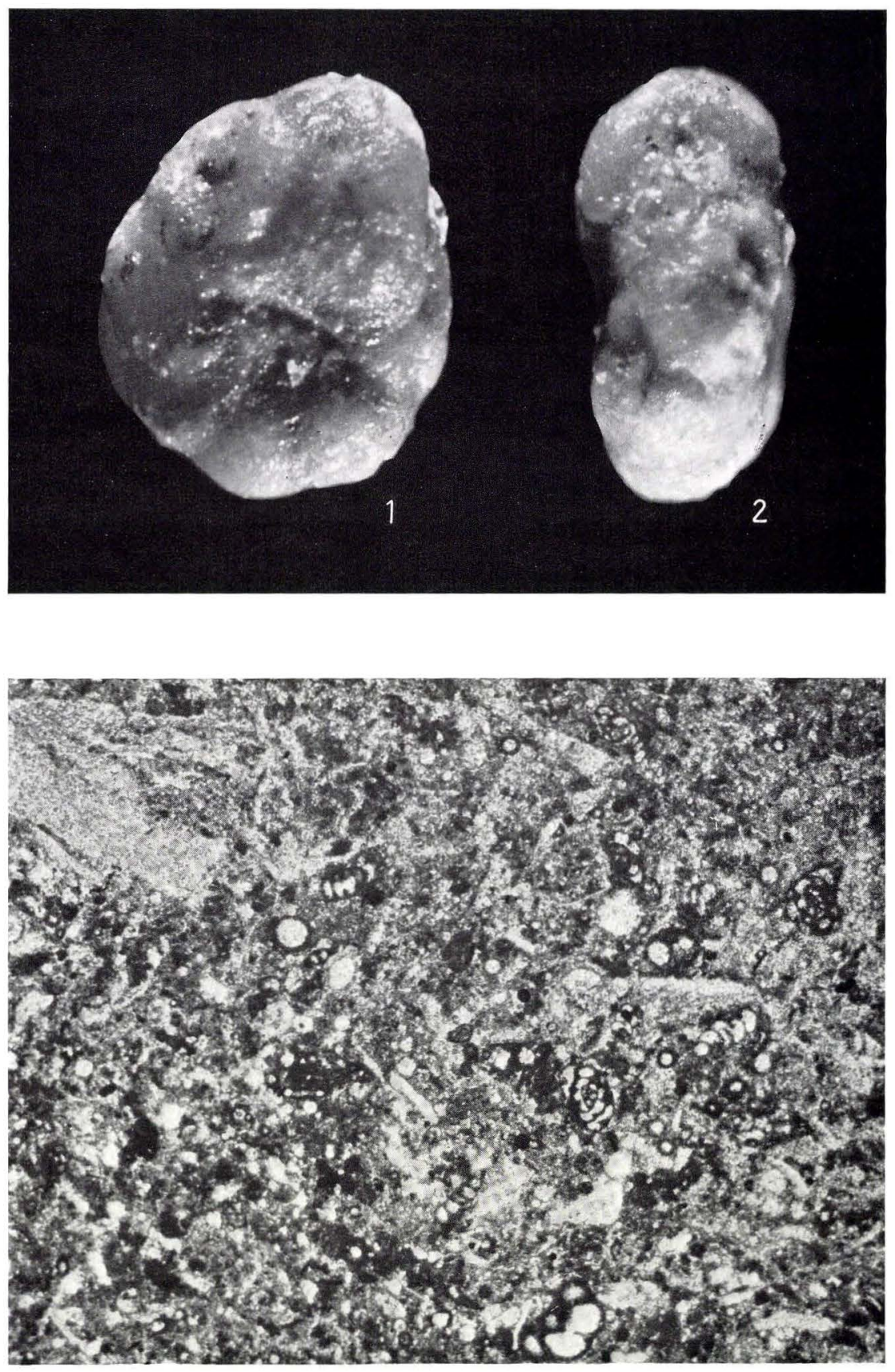
Fig. 1. Thin-section of the marlstone (claystone) from core No. 2, depth $7710^{\prime} 2^{\prime \prime}$.

Fig. 2. Thin-section of the marlstone (claystone) from core No. 2, depth $7745^{\prime} 5^{\prime \prime}$.

Phot. O. Neergaard Rasmussen. 


FORAMINIFERA OF THE LOWER CARBONIFEROUS SECTION OF THE BORING ORSLEV NO. 1, ISLAND OF FALSTER, DENMARK

OLAF MICHELSEN

D.G.U. Sept. 1970

ELEVATION :

Ground $+16.4 \mathrm{~m}\left(54^{\prime}\right)$

Kelly Bushing $+22.7 \mathrm{~m}(74)$

辠

LITHOLOGY

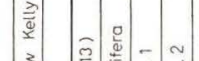

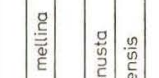

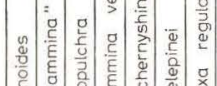

(2)

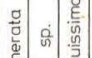

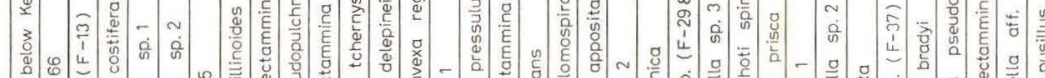

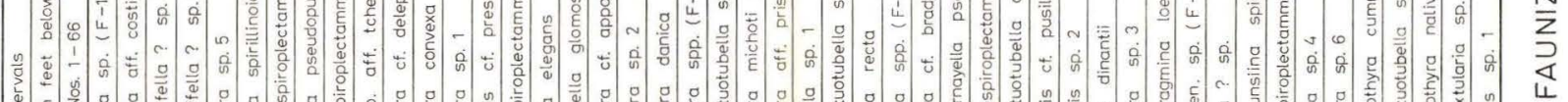

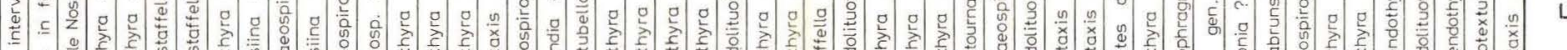

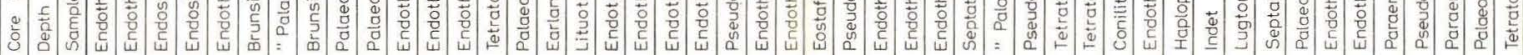

¿े

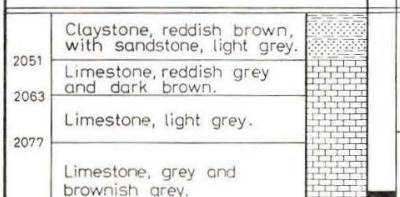

-

Marlstone, grey to
dark grey, with sand.
$2160-2209 \mathrm{~m}$ : Interbedded
with sandstone.

1

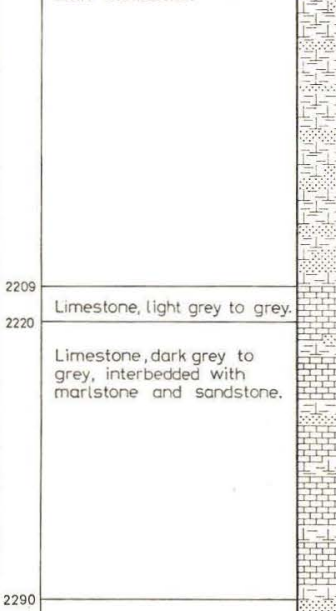

Sandstone, light grey to
grey, interbedded with grey, interbedded with part of the section

2332

Claystone (marlstone), grey
to dark grey, calcareous, and limes

Limestone, grey to dark
grey, with calcareous grey, with calcareous
claystone (marlstone).

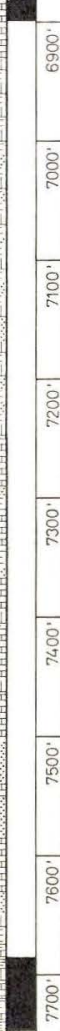

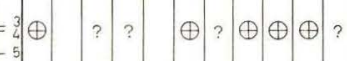

9. $\oplus \oplus$

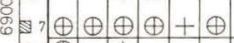

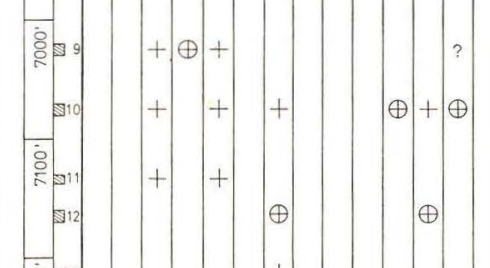

$+\oplus ? \oplus$

$\oplus \oplus$

$\oplus ? \oplus$

$\oplus$

$\oplus \oplus \oplus \oplus$

$\oplus ?$

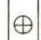

$\oplus$
LEGEND

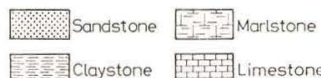

- Core sample

Ditch sample, all foraminifera picked out

$\longmapsto$ Ditch sample, only selected species picked

$+\begin{aligned} & \text { Species determina } \\ & \text { ternal morphology }\end{aligned}$

$\oplus$ Species determination on basis of ex-

? Uncertain determination
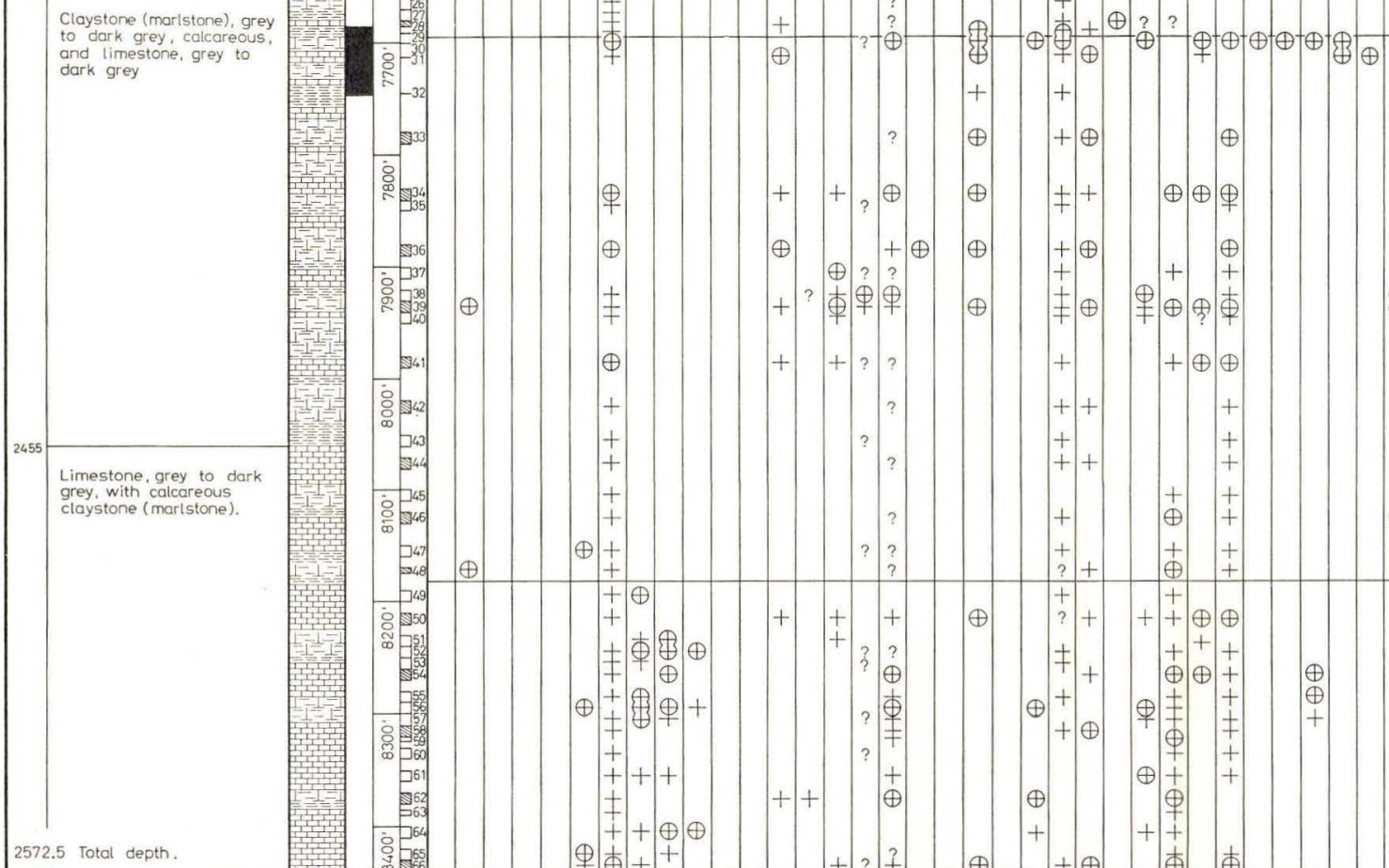

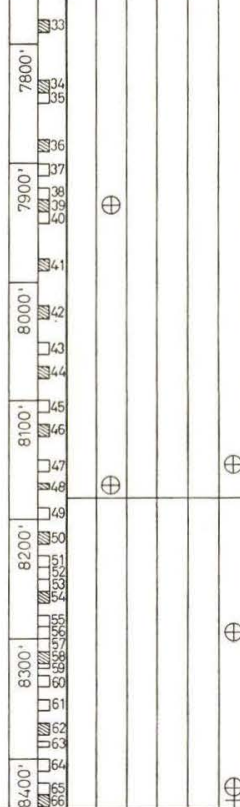

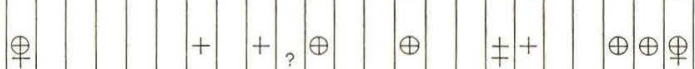

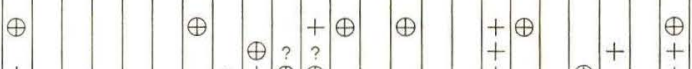

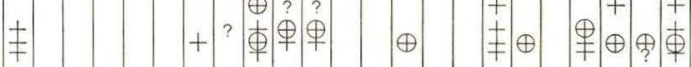

$\oplus \hat{\oplus} \oplus$

$\oplus \oplus_{\oplus}^{\oplus} \oplus$

III

$\pm \bar{\mp} \oplus \underset{\oplus}{\oplus} \oplus$

$\oplus+\Theta \oplus \oplus+$

$+? ? ?$

$+++\infty \oplus++\stackrel{+}{\oplus}$

$++\oplus \oplus$

$+\quad+\oplus \oplus$

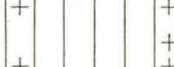

$+$
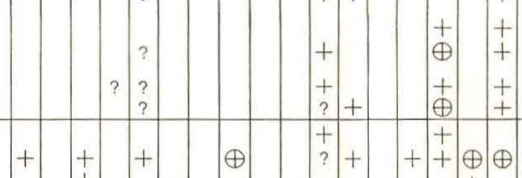

$\left[\begin{array}{l}? \\ \ddagger \\ +\end{array}++\begin{array}{ccc}+ & \oplus & \oplus \\ + & \oplus \\ \oplus & + \\ \oplus & +\end{array}\right.$

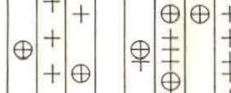

$\oplus$

$\oplus \begin{gathered}\oplus+ \\ \oplus \\ \oplus\end{gathered}$

$+$

$+\begin{array}{r}+ \\ +\end{array}$

$\oplus$
$\oplus$
+

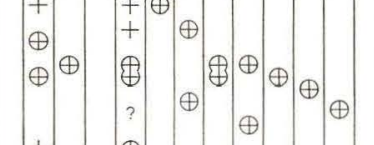

IV 